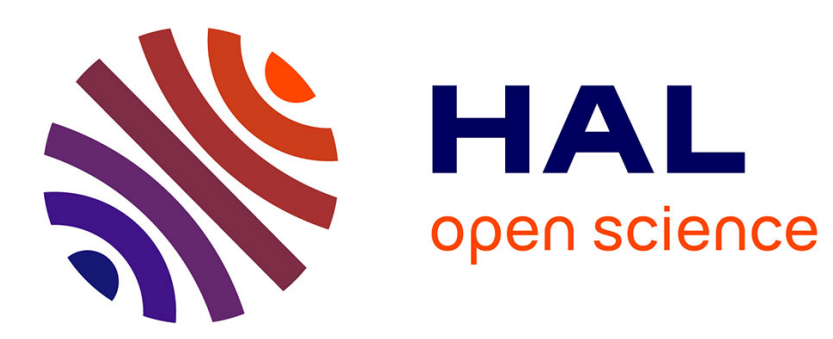

\title{
The Determinants of Unemployment across OECD Countries
}

\author{
Andrea Bassanini, Romain Duval
}

\section{To cite this version:}

Andrea Bassanini, Romain Duval. The Determinants of Unemployment across OECD Countries: Reassessing the Role of Policiesand Institutions. OECD Economic Studies, 2006, 42, pp.7-86. halshs00120584

\section{HAL Id: halshs-00120584 https://shs.hal.science/halshs-00120584}

Submitted on 7 Nov 2007

HAL is a multi-disciplinary open access archive for the deposit and dissemination of scientific research documents, whether they are published or not. The documents may come from teaching and research institutions in France or abroad, or from public or private research centers.
L'archive ouverte pluridisciplinaire HAL, est destinée au dépôt et à la diffusion de documents scientifiques de niveau recherche, publiés ou non, émanant des établissements d'enseignement et de recherche français ou étrangers, des laboratoires publics ou privés. 


\title{
THE DETERMINANTS OF UNEMPLOYMENT ACROSS OECD COUNTRIES: REASSESSING THE ROLE OF POLICIES AND INSTITUTIONS
}

\author{
Andrea Bassanini and Romain Duval \\ TABLE OF CONTENTS
}

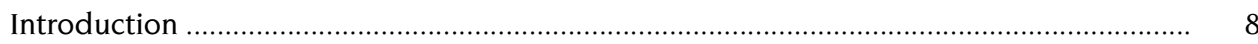

Direct effects of policies and institutions on unemployment: the baseline specification 9

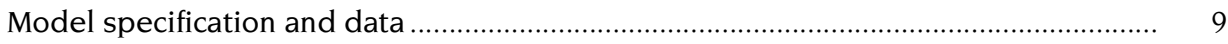

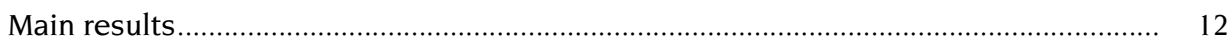

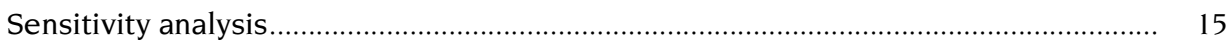

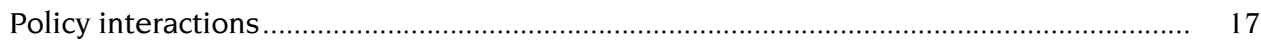

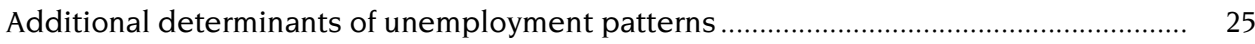

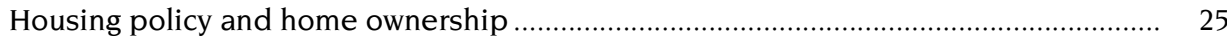

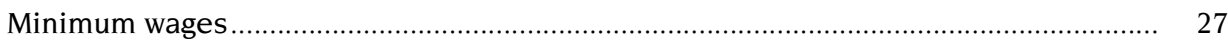

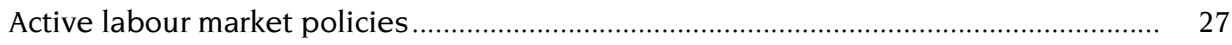

Interactions between institutions and shocks........................................................... 33

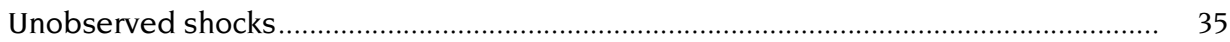

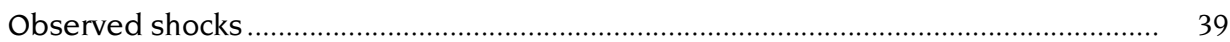

Disentangling amplification from persistence effects ............................................... 41

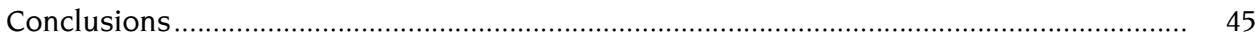

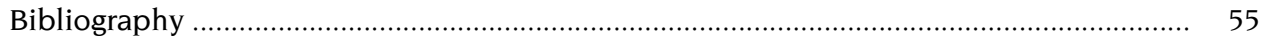

Annex 1. Theoretical foundations and previous cross-country empirical evidence .......... 60

Annex 2. Data construction and sources ........................................................................... 79

Andrea Bassanini and Romain Duval are economists at the Directorate for Employment, Labour and Social Affairs and the OECD Economics Department, respectively. Catherine Chapuis-Grabiner, Sébastien Martin and Rebecca Oyomopito provided excellent research assistance. Comments from Sveinbjorn Blöndal, Wendy Carlin, Jean-Philippe Cotis, Martine Durand, Jorgen Elmeskov, Michael P. Feiner, David Howell, Etienne Lehmann, Edmond Malinvaud, John P. Martin, Giuseppe Nicoletti, Stefano Scarpetta, Paul Swaim, Raymond Torres and participants to the joint WP1/WP5 EPC-ELSAC meeting in Paris, January 2006, and the Séminaire Fourgeaud, Paris, May 2006, are also gratefully acknowledged. Any errors are the responsibilities of the authors alone. The views expressed in this paper are those of the authors, and do not necessarily reflect those of the OECD or of its member countries. 


\section{INTRODUCTION}

The 1994 OECD Jobs Strategy stressed the need for fundamental labour market reforms to deal with high and persistent unemployment that affected many member countries (OECD, 1994, 1997). The case for policy reforms made in the 1994 Jobs Strategy was based on a careful scrutiny of the evidence (both qualitative and quantitative) available at the time. Since then, empirical research on the topic has improved on two fronts. First, microeconometric techniques for policy evaluation have evolved and new evidence has become available (see e.g. OECD, 2006a). Second, the OECD has constructed several indicators of policies and institutions that are comparable both across countries and over time. These indicators have been used in a wide range of macroeconometric studies to explore the labour market effects of policies and institutions. While the main policy conclusions from these studies have generally been consistent with the main thrust of the 1994 Jobs Strategy, some of the recommendations have also been challenged in some cases (see Annex 1 for references). The purpose of this paper is to reassess and extend the recent macroeconometric evidence, taking into account recent advances in both theoretical and empirical analysis, in order to provide, together with existing microevaluation studies, a more reliable empirical basis for assessing policy choices (see e.g. OECD, 2006b).

The paper studies the impact of structural policies and institutions on aggregate unemployment. To this end, heavy reliance is made of cross-country/time-series econometric techniques, which have been used extensively in the empirical literature over recent years. Yet, one distinguishing feature of this paper with respect to most of the existing literature ${ }^{1}$ is that particular care is taken throughout to assess and document what findings are robust and what are not. Although the main focus of the paper is on labour market policies and institutions, other issues that have emerged more recently in the literature are also covered, including the role of product market regulation, interactions among structural policies, and the effects of policies and institutions on economic resilience to macroeconomic shocks.

The paper is divided into four main sections. The first section reassesses existing evidence by means of new panel data econometric estimates spanning the past two decades. Particular emphasis is put on the unemployment effects of tax wedges, unemployment benefit systems, employment protection legislation, product market regulation and wage-bargaining systems. The following section explores the extent to which interactions across these policies and institutions matter.

$\overline{\text { C) OECD } 2006}$ 
The third section brings into the picture additional institutions which for various reasons could not be incorporated earlier in the analysis, including housing policies, statutory minimum wages and active labour market policies. Finally, the fourth section undertakes an analysis over a longer time period of how policies and institutions contribute to shape unemployment patterns not only directly but also indirectly via their interaction with macroeconomic shocks. Conclusions follow.

\section{DIRECT EFFECTS OF POLICIES AND INSTITUTIONS ON UNEMPLOYMENT: THE BASELINE SPECIFICATION}

Economic theory and previous empirical studies have identified a number of policy and institutional determinants of unemployment. These include inter alia unemployment benefits, taxes, trade union bargaining power and the structure of collective bargaining, employment protection legislation (EPL), anti-competitive product market regulation (PMR), active labour market policies (ALMPs), minimum wages and housing policies. ${ }^{2}$

Overall, there is fairly robust evidence that the level and duration of unemployment benefits have a significantly positive impact on unemployment (Scarpetta, 1996; Nickell, 1998; Elmeskov et al., 1998; Nunziata, 2002). Likewise, a number of empirical studies have found that high labour taxes tend to increase unemployment rates (Belot and van Ours, 2004; Nickell, 1997), although other studies are less conclusive (Scarpetta, 1996; Elmeskov et al., 1998; Nunziata, 2002; Macculloch and DiTella, 2002). Some macroeconometric studies also identify a favourable effect of ALMP spending and an adverse impact of home ownership on aggregate unemployment but fail to agree on their magnitudes (e.g. Scarpetta, 1996; Nickell, 1997, 1998; Green and Hendershott, 2001, Boone and van Ours, 2004, Nickell et al., 2005).

There is less consensus in the literature on the unemployment effects of EPL, trade union bargaining power, the structure of collective bargaining. Finally, there is only scant macroeconometric evidence on the employment effects of product market regulation. Among the few studies on this issue, Nicoletti et al. (2001) and Nicoletti and Scarpetta (2005) both find that product market reforms improve labour market performance. Annex 1 provides a more comprehensive theoretical and empirical survey of the impact of policies and institutions on employment.

\section{Model specification and data}

In this section, pooled cross-country/time-series econometric analysis is used to explore the direct effects of policies and institutions on unemployment - i.e. omitting at this stage possible interactions between institutions as well as interactions between institutions and shocks. The main policy and institutional determinants of unemployment are introduced into a reducedform unemployment equation that is consistent with a variety of theoretical models of labour market equilibrium, including standard job-search (Pissarides, 2000) 
and wage-setting/price-setting (e.g. Layard et al. 1991; Nickell and Layard, 1999) models. More specifically, the following static model is estimated for a sample of 20 OECD countries ${ }^{3}$ over the period 1982-2003:

$$
U_{i t}=\sum_{j} \beta_{j} X_{i t}^{j}+\chi G_{i t}+\alpha_{i}+\lambda_{t}+\varepsilon_{i t}
$$

where $\mathrm{i}$ and $\mathrm{t}$ are country and time suffices, $\mathrm{U}_{i t}$ is the standardised rate of unemployment, $\mathrm{G}_{i t}$ is the OECD measure of the output gap - and aims to control for the unemployment effects of aggregate demand fluctuations over the business cycle, while $\alpha_{i}$ and $\lambda_{t}$ are country and time fixed effects. ${ }^{4}$ Finally, the X's are OECD measures of the policies and institutions considered as explanatory variables, namely: the tax-wedge between labour cost and take-home pay (for a single-earner couple with two children, at average earnings levels); a summary measure of unemployment benefit generosity (an average of replacement rates across various earnings levels, family situations and durations of unemployment); the degree of stringency of EPL; the average degree of stringency of PMR across seven non-manufacturing industries; ${ }^{5}$ union membership rates; the degree of centralisation/co-ordination of wage bargaining, a proxy for the concept of "corporatism" which has received widespread attention in the comparative political economy literature. As already done in a number of previous papers (e.g. Scarpetta, 1996, Elmeskov et al., 1998), dummies for different levels of corporatism are used here to capture non-linearities in the effect of corporatism. In order to do so, the quantitative indicator of "coordination of wage-bargaining" developed in OECD (2004) - which corresponds to the standard definition of centralisation/co-ordination of the wage-bargaining used by previous studies - has been aggregated into three classes (low, intermediate and high). In principle, the baseline specification includes a dummy variable for intermediate corporatism. However, given that no country moved in or out of the intermediate level of corporatism over the sample period, the effect of this variable can not be identified - even if controlled for - and therefore is not reported in the following tables and charts.

The rationale for including these explanatory variables in the equation is discussed in detail in the literature review provided in Annex 1. Other potential candidates for explaining unemployment patterns include housing policy, minimum wage and active labour market policies - ALMPs. However, due to data quality and/or econometric issues, they require specific treatment and therefore will be dealt with in a specific section.

In a number of specifications, the output gap is substituted for by several macroeconomic variables which aim to capture more directly the unemployment impact of aggregate shocks. In line with recent empirical literature, four types of "shocks" are considered for analysis:

- Total factor productivity (TFP) shocks, defined here as the deviation of the logarithm of TFP from its trend calculated by means of a Hodrick-Prescott filter. 
In the presence of lagged wage adjustment to productivity growth, positive (negative) productivity surprises - as measured here by a positive gap between actual and trend TFP - should induce a temporary decline (increase) in structural unemployment (see e.g. Ball and Moffitt, 2002; Meyer, 2000). ${ }^{6}$

- Terms of trade shocks, defined as the ratio of imports to output multiplied by the logarithm of their relative prices $\left((\mathrm{M} / \mathrm{Y}) \log \left(\mathrm{P}_{\mathrm{M}} / \mathrm{P}_{\mathrm{Y}}\right)\right)$, i.e. in such a way that its growth rate is the change in the relative price of imports weighted by the share of imports in GDP. By widening the wedge between consumer and producer prices, a rise in the relative price of imports should increase wage pressure and, ultimately, unemployment (see e.g. Layard et al., 1991).

- Real interest rate shocks, defined as the difference between the 10-year nominal government bond yield and the annual GDP price inflation. A rise in real interest rates affects negatively capital accumulation and labour productivity, thereby reducing labour demand (at a given wage level) and increasing unemployment (see e.g. Blanchard, 1999, 2000).

- In some specifications, labour demand shocks, defined as the logarithm of the labour share in business-sector GDP purged from the short-run influence of factor prices. ${ }^{7}$ As discussed in Blanchard (1998), this variable could rise for two possible reasons: $i$ ) a decline in the gap between the wage rate and the marginal product of labour, e.g. due to labour shedding by firms following a weakening of union power and/or rising pressures from capital markets to increase the rate of return on capital; or ii) a shift in production techniques away from labour and towards capital. In both cases, this can be interpreted as an adverse labour demand shock that is set to raise unemployment. The former explanation has been for instance put forward to account for the concomitance of a continued decline in the labour share and a rise in unemployment in certain European countries in the 1980s and part of the 1990s.

Full details on data as well as descriptive statistics are provided in Annex 2.

One important adjustment made to the data sample and specifications should be mentioned at the outset. In both the descriptive and panel data analyses below, observations for Finland, Germany and Sweden in 1991 and 1992 are removed from the sample, and different country fixed effects are used for each of these three countries over the two sub-periods 1982-1990 and 1993-2003. In practice, this approach is equivalent to splitting Finland, Germany and Sweden into two sub-countries, pre- and post-1991/1992. ${ }^{8}$ This reflects the view that for these three countries, neither the institutions, nor the set of macroeconomic shocks considered in this section, are able to capture the highly country-specific factors including inter alia, the collapse of the Soviet Union, the unification and the banking crises, respectively - which were behind the upward shift in unemployment 
over this two-year period. Therefore, keeping these six observations within the sample could increase the risk of estimate bias. Still, as will be shown below, the main conclusions from the analysis are not dependent on whether these observations are excluded from the sample.

\section{Main results}

Baseline regression results are presented in Table 1. Tax wedges, average benefit replacement rates and PMR are estimated to raise aggregate unemployment, while EPL and union density are statistically insignificant at conventional confidence levels (column 1). The significant impact of the OECD summary measure of benefit replacement rates reflects the combined effect of the replacement rate during the first year of unemployment, the duration of benefit receipt and the interaction between these variables - all of which are statistically significant (column 2). Furthermore, the degree of corporatism is found to significantly reduce unemployment, lending some support to the view that, in centralised/ co-ordinated bargaining systems, unions and employers are able to internalise the adverse employment consequences of excessive wage claims. Yet, this effect is identified by only four within sample shifts in the type of bargaining system, ${ }^{9}$ and therefore it should be seen as somewhat more tentative.

The finding that the unemployment effects of both union density and EPL are statistically insignificant is not necessarily inconsistent with either theory ${ }^{10}$ or empirical studies. However, this needs to be qualified. As discussed in Annex 1, union density might poorly capture the actual bargaining power of workers. Indeed, in some countries, the coverage of collective agreements largely exceeds the number of trade union members - this reflects, inter alia, legal procedures and practices to extend collective contracts to unaffiliated workers, including those employed in non-signatory firms. Likewise, the absence of a significant impact of EPL on aggregate unemployment is in line with a number of previous studies (see in particular OECD, 2004). But the insignificant coefficient may mask two opposite effects, with EPL on regular contracts exerting upward pressure on unemployment and EPL on temporary contracts pushing in the opposite direction (see column 3 of Table 1). ${ }^{11}$ While supporting certain recent theoretical developments mentioned earlier, this latter finding should be viewed as highly fragile, as it disappears if Spain - the country which undertook the deepest reforms of EPL for permanent workers over the period considered - is removed from the sample. ${ }^{12}$

The measure of the tax wedge used in the baseline equation (column 1) is derived from OECD tax models and therefore only captures labour taxes (social security contributions and income taxes), but not consumption taxes. ${ }^{13}$ A broader measure of the tax wedge, which covers both labour and consumption taxes, has

12 been derived from National Accounts - following the approach of Carey and Rabesona 
Table 1. Baseline unemployment rate equation, 1982-2003

\begin{tabular}{|c|c|c|c|c|c|c|c|}
\hline & 1 & 2 & 3 & 4 & 5 & 6 & 7 \\
\hline & $\begin{array}{l}\text { Excluding } \\
\text { Germany, } \\
\text { Finland and } \\
\text { Sweden } \\
\text { 1990-1991, } \\
\text { common OG }\end{array}$ & $\begin{array}{c}\text { = } 1 \\
\text { with } \\
\text { RR } \\
\text { split } \\
\text { into } 2 \\
\text { components }\end{array}$ & $\begin{array}{c}=1 \\
\text { with } \\
\text { EPL } \\
\text { split } \\
\text { into } 2 \\
\text { components }\end{array}$ & $\begin{array}{c}=1 \\
\text { with } \\
\text { tax wedge } \\
\text { derived from } \\
\text { National } \\
\text { Accounts }\end{array}$ & $\begin{array}{c}=4 \\
\text { with } \\
\text { separate } \\
\text { labour and } \\
\text { consumption } \\
\text { tax rates }\end{array}$ & $\begin{array}{c}=1 \\
\text { with } \\
\text { standard } \\
\text { macro- } \\
\text { economic } \\
\text { shocks }\end{array}$ & $\begin{array}{c}=6 \\
\text { with } \\
\text { labour } \\
\text { demand } \\
\text { shock }\end{array}$ \\
\hline Average replacement & 0.12 & & 0.12 & 0.08 & 0.09 & 0.10 & 0.09 \\
\hline rate (RR) & {$[6.28]^{* * *}$} & & {$[6.79]^{* * *}$} & {$[4.22]^{* * *}$} & {$[4.16]^{* * *}$} & {$[4.14]^{* * *}$} & {$[3.35] * * *$} \\
\hline Tax wedge & $\begin{array}{c}0.28 \\
{[9.75]^{* * *}}\end{array}$ & $\begin{array}{c}0.27 \\
{[10.96]^{* * *}}\end{array}$ & $\begin{array}{c}0.27 \\
{[11.14]^{* * *}}\end{array}$ & $\begin{array}{l}0.24 \\
{[4.49]^{* * *}}\end{array}$ & & $\begin{array}{l}0.24 \\
{[7.73]^{* * *}}\end{array}$ & $\begin{array}{l}0.22 \\
{[6.40] * * *}\end{array}$ \\
\hline Union density & $\begin{array}{c}-0.03 \\
{[1.57]}\end{array}$ & $\begin{array}{l}-0.03 \\
{[1.89]^{*}}\end{array}$ & $\begin{array}{l}-0.03 \\
{[1.64]}\end{array}$ & $\begin{array}{l}-0.02 \\
{[0.56]}\end{array}$ & $\begin{array}{l}-0.01 \\
{[0.49]}\end{array}$ & $\begin{array}{c}0.04 \\
{[1.48]}\end{array}$ & $\begin{array}{l}0.06 \\
{[2.33]^{* *}}\end{array}$ \\
\hline EPL & $\begin{array}{l}-0.31 \\
{[0.98]}\end{array}$ & $\begin{array}{l}-0.20 \\
{[0.55]}\end{array}$ & & $\begin{array}{c}0.03 \\
{[0.08]}\end{array}$ & $\begin{array}{c}0.01 \\
{[0.02]}\end{array}$ & $\begin{array}{c}-0.61 \\
{[-1.52]}\end{array}$ & $\begin{array}{l}-0.51 \\
{[-1.22]}\end{array}$ \\
\hline PMR & $\begin{array}{c}0.60 \\
{[2.98]^{* * *}}\end{array}$ & $\begin{array}{l}0.67 \\
{[3.29]^{* * *}}\end{array}$ & $\begin{array}{l}0.73 \\
{[3.52]^{* * *}}\end{array}$ & $\begin{array}{c}0.50 \\
{[2.17]^{* *}}\end{array}$ & $\begin{array}{c}0.50 \\
{[2.17]^{* *}}\end{array}$ & $\begin{array}{l}0.54 \\
{[2.25] * *}\end{array}$ & $\begin{array}{l}0.79 \\
{[3.28]^{* * *}}\end{array}$ \\
\hline High corporatism & $\begin{array}{l}-1.42 \\
{[3.57]^{* * *}}\end{array}$ & $\begin{array}{l}-1.09 \\
{[2.88]^{* * *}}\end{array}$ & $\begin{array}{l}-1.39 \\
{[3.94]^{* * *}}\end{array}$ & $\begin{array}{l}-2.06 \\
{[4.80]^{* * *}}\end{array}$ & $\begin{array}{l}-2.09 \\
{[4.89]^{* * *}}\end{array}$ & $\begin{array}{l}-1.42 \\
{[-2.90] * *}\end{array}$ & $\begin{array}{l}-1.58 \\
{[-3.26] * * *}\end{array}$ \\
\hline Output gap & $\begin{array}{c}-0.48 \\
{[14.00]^{* * *}}\end{array}$ & $\begin{array}{l}-0.48 \\
{[14.21]^{* * *}}\end{array}$ & $\begin{array}{l}-0.47 \\
{[13.99]^{* * *}}\end{array}$ & $\begin{array}{l}-0.54 \\
{[11.89]^{* * *}}\end{array}$ & $\begin{array}{l}-0.54 \\
{[11.60]^{* * *}}\end{array}$ & & \\
\hline RR 1st year & & $\begin{array}{l}0.09 \\
{[7.37]^{* * *}}\end{array}$ & & & & & \\
\hline Benefit duration & & $\begin{array}{l}2.64 \\
{[2.03]^{* *}}\end{array}$ & & & & & \\
\hline (RR 1st)*(duration) & & $\begin{array}{l}0.09 \\
{[2.69]^{* * *}}\end{array}$ & & & & & \\
\hline EPL regular & & & $\begin{array}{c}1.28 \\
{[2.49]^{* *}}\end{array}$ & & & & \\
\hline EPL temporary & & & $\begin{array}{l}-0.45 \\
{[2.16]^{* *}}\end{array}$ & & & & \\
\hline$($ EPL reg $) *($ EPL temp $)$ & & & $\begin{array}{l}-0.28 \\
{[1.21]}\end{array}$ & & & & \\
\hline Labour tax rate & & & & & $\begin{array}{l}0.25 \\
{[4.82]^{* * *}}\end{array}$ & & \\
\hline Consumption tax rate & & & & & $\begin{array}{c}0.21 \\
{[1.92]^{*}}\end{array}$ & & \\
\hline Macroeconomic shock & cks: & & & & & & \\
\hline TFP shock & & & & & & $\begin{array}{l}-12.81 \\
{[-3.34] * * *}\end{array}$ & $\begin{array}{l}-8.87 \\
{[-2.33] * *}\end{array}$ \\
\hline Terms of trade shock & & & & & & $\begin{array}{l}19.40 \\
{[6.45] * * *}\end{array}$ & $\begin{array}{l}19.09 \\
{[6.09]^{* * *}}\end{array}$ \\
\hline Interest rate shock & & & & & & 0.22 & 0.19 \\
\hline Labour demand shock & & & & & & {$[2.72] * * *$} & $\begin{array}{l}{[2.44]^{* *}} \\
11.79 \\
{[3.91]^{* * *}}\end{array}$ \\
\hline Country dummies & Yes & Yes & Yes & Yes & Yes & Yes & Yes \\
\hline Time dummies & Yes & Yes & Yes & Yes & Yes & Yes & Yes \\
\hline Observations & 434 & 434 & 434 & 398 & 398 & 419 & 397 \\
\hline R-squared & 0.98 & 0.92 & 0.92 & 0.98 & 0.98 & 0.98 & 0.98 \\
\hline
\end{tabular}

$\mathrm{OG}=$ output gap. Absolute value of robust $\mathrm{t}$ statistics in brackets.

${ }^{*}, * *, * * *$ statistically significant at the $10 \%, 5 \%$ and $1 \%$ levels, respectively.

Source: Authors' estimates on the basis of data sources described in Annex 2. 
(2002) - in order to check the robustness of the results. Such a National Accounts measure of the tax wedge is more likely to suffer from endogeneity problems and provides a cruder picture of the tax incentives effectively faced by individuals than the tax model measure of the tax wedge. This is why the latter is used throughout the present paper (with the exception of the last section on macroeconomic shocks below), despite being only a measure of the labour tax wedge. Re-estimating the baseline equation using the National Accounts measure yields similar coefficients for all the explanatory variables including the tax wedge itself (Table 1, column 4). Moreover, consistent with theoretical priors, no significant difference is found between the impact of labour and consumption taxes (Table 1, column 5).

The estimated coefficient of the output gap is highly significant in all specifications. This result points to the importance of cyclical unemployment patterns that can be explained by macroeconomic shocks. ${ }^{14}$ In order to shed further light on this issue, the baseline equation is re-estimated by substituting a number of observable macroeconomic variables, or "shocks", for the output gap (Table 1, columns 6 and 7).

Re-estimating the baseline regression with a set of observed shocks instead of the output gap term yields highly significant and correctly signed coefficients for TFP, terms of trade and interest rate shocks (column 6), as well as for the labour demand one (column 7). In terms of these estimates, whether the effect of shocks is temporary or permanent depends on whether shocks are stationary or not. However, this cannot be tested for in a reliable way given the small size of the estimation sample and the high degree of persistence of unemployment. In any event, one important and reassuring feature of the estimates in Table 2 is that no estimated parameter of policies and institutions - with the partial exception of union density - depends on whether the equation controls for business cycle effects via the output gap or the set or macroeconomic shocks used in this paper.

In general, therefore, these results suggest that labour- and product-market reforms can have sizeable effects on unemployment. Taking the baseline estimates (Table 1, column 1) at face value, for example, a 10 percentage point cut in the tax wedge, a 10 percentage point reduction of unemployment benefits and/or a decline in product market regulation by two standard deviations ${ }^{15}$ would on average be associated with a drop in the unemployment rate by $2.8,1.2$ and 0.7 percentage points, respectively.

Overall, the baseline equation appears to explain a significant share of past unemployment trends for most countries (Figure 1, Panel A). This is true even when considering the impact of policies and institutions alone, i.e. excluding the effects of the output gap (Figure 1, Panel B). Changes in policies and institutions 14 between 1982 and 2003 are estimated to explain $47 \%$ of the cross-country variance 
of observed unemployment changes over the same period. This figure rises to $74 \%$ when changes in both policies and the output gap are taken into account (the difference between the two figures reflecting the fact that certain countries were in different phases of the business cycle at the beginning and at the end of the observation window). As a consequence, $64 \%$ of the cross-country variation in noncyclical unemployment changes ${ }^{16}$ between 1982 and 2003 can be attributed to changes in policies and institutions.

Many of the countries that, as shown in Figure 1, succeeded in lowering unemployment reduced tax wedges and/or unemployment benefits (e.g. Denmark, Ireland, United Kingdom), while policy changes were typically not employmentfriendly in those countries where unemployment stagnated or rose (e.g. France, Japan, Switzerland). In addition, the general move towards less regulated product markets has contributed to improve the unemployment record. Yet, for certain countries (e.g. Canada, Finland, Spain and Sweden), labour market performance between 1982 and 2003 is essentially explained by the output gap, pointing to the fact that these countries were in different phases of the business cycle at the beginning and at the end of the period under analysis (compare Figure 1, Panel A with Figure 1, Panel B). Finally, there are some countries for which past unemployment trends are harder to explain. In particular, the gradual pick up in unemployment in Germany since unification is not properly explained by either policy or control variables included in the analysis. By contrast, the drop in unemployment in the Netherlands since the early 1980s has been larger than predicted by the model.

\section{Sensitivity analysis}

While panel data econometric approaches have been used extensively to explain the cross-country and time-series patterns of unemployment, it has sometimes been argued that their findings are not sufficiently robust across samples, model specifications or estimation techniques (Baker et al., 2004; Baccaro and Rei, 2005). In any event, any inference from models estimated on a small panel data set and including qualitative variables should be made with care. In order to check the robustness of the above results, a thorough sensitivity analysis of the baseline equation estimated in column 1 has been carried out (see Bassanini and Duval, 2006, for details). The key finding is that the significant unemployment effects of tax wedges, average benefit replacement rates, product market regulation and high corporatism are robust to:

- The choice of the estimation sample. The results do not hinge on whether the six observations that correspond to the 1990 and 1991 idiosyncratic shocks in Finland, Germany and Sweden are removed from the sample and different fixed effects are used over the two sub-periods 1982-1989 and 1992-2003. Likewise, excluding from the sample either influential observations (statistical 
Figure 1. The baseline unemployment rate equation: explaining past unemployment trends

Panel A. Change in unemployment explained by policies and output gap, 1982-2003

Observed change in unemployment rate

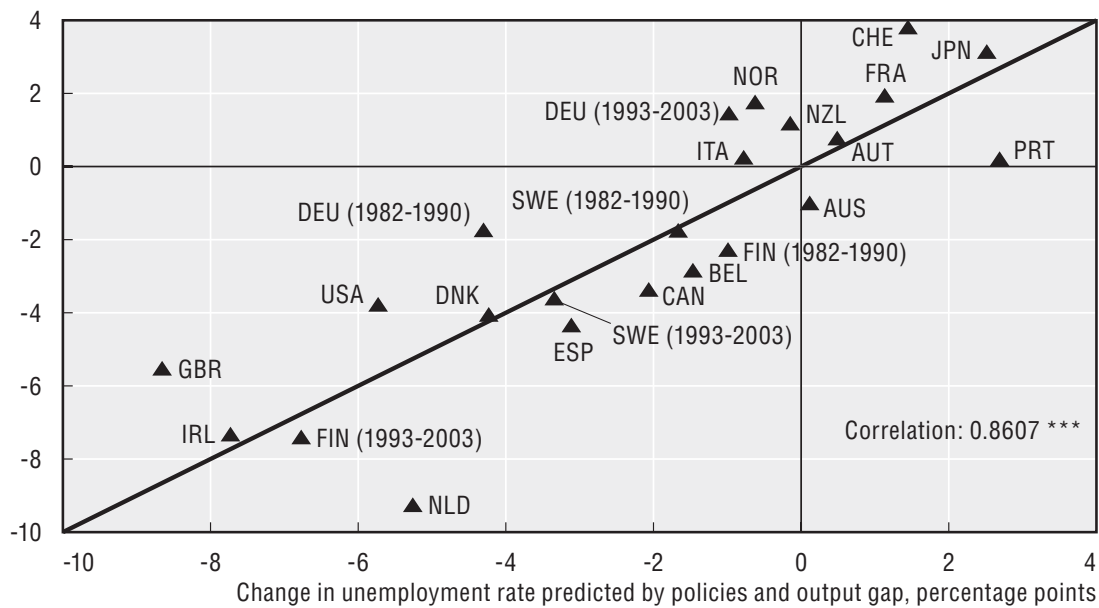

Panel B. Change in unemployment and policies, 1982-2003

Observed change in unemployment rate

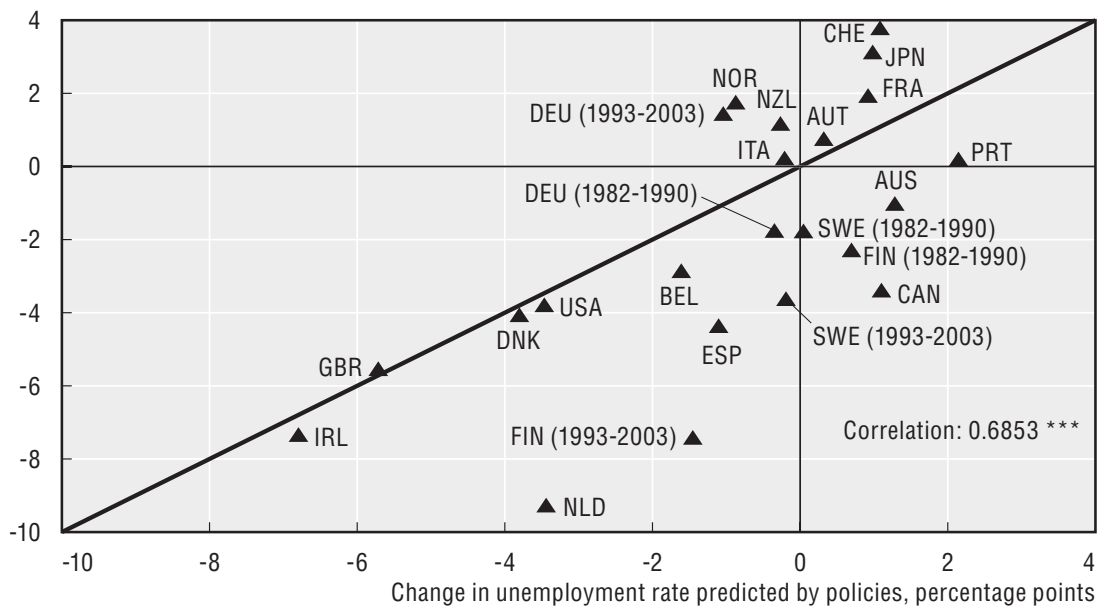

Estimates on the basis of the unemployment rate equation in Table 1, column 1.

Source: Authors' estimates on the basis of data sources described in Annex 2.

outliers), or any particular country, or any random draw of $10 \%$ of observations, has no noticeable impact. Furthermore, the estimated equation seems to fulfil its objective to capture some long-run relationship between unemployment 
and policies and institutions. Indeed, the set of coefficients obtained when reestimating the model using five-year averages is not found to be significantly different from that obtained when using annual data.

- Model specifications. Dropping time effects and/or the output gap variable, or considering country-specific coefficients for the latter variable, does not affect the main findings.

- Estimation techniques. Feasible Generalised Least Squares (FGLS) with random effects yield comparable results, as do FGLS with fixed effects and country-wise heteroskedasticity. ${ }^{17}$

In addition, estimates obtained from the baseline model do not appear to be affected by heterogeneity bias. The latter may arise if the impact of a given policy or institution varies across countries, due for instance to the existence of policy interactions. In such a situation, pooled regressions assuming common coefficients for all countries can yield inconsistent estimates of the average impact of certain explanatory variables (see e.g. Pesaran and Smith, 1995). Here, Hausman tests on the absence of heterogeneity bias (see Bassanini and Duval, 2006) suggest that the baseline regression yields consistent estimates of the average impact of each policy or institution. ${ }^{18}$

Another potential concern is the risk of reverse causality, reflecting some degree of endogeneity of policies and institutions with respect to unemployment patterns. For instance, the observed relationship between benefit replacement rates and unemployment may reflect governments' propensity to raise (cut) benefits when unemployment is high (low) - i.e. there may be cases where causality runs from unemployment changes to policy changes. While there is no straightforward way to address this issue, it is still possible to attempt to control for policy endogeneity by means of instrumental variable (IV) techniques. Here, the baseline equation is found to be reasonably robust to the use of a Generalised Method of Moments (GMM) estimator, in which all policies and institutions - with the exception of the degree of corporatism - are assumed to be endogenous.

\section{POLICY INTERACTIONS}

A number of researchers have argued on both theoretical and empirical grounds that comprehensive policy packages are likely to be more effective at reducing unemployment than "piece-meal" labour market reforms (Belot and Van Ours, 2004; Coe and Snower, 1997; Elmeskov et al., 1998; Fitoussi et al., 1998; Orszag and Snower, 1998). Recent descriptive evidence on labour market reforms in OECD countries does not provide straightforward evidence for the existence of successful policy packages (Brandt et al. 2005): while several countries that succeeded in lowering unemployment have applied comprehensive reforms programmes (Denmark, Netherlands), in other successful countries reforms have been more 
narrowly targeted on specific fields (Ireland, United Kingdom). To shed further light on this question, this section undertakes an econometric analysis of interactions among policies and institutions (the way theory has treated policy interactions in the context of unemployment analysis is briefly discussed in Box 1). To this end, the baseline model of the previous section - which estimates only "average" effects of policies and institutions irrespective of possible interactions among them - is extended in various ways to allow for interaction effects.

Interactions among institutions in macroeconometric equations are usually specified as multiplicative terms, which take the form of products of deviations of institutions from their sample mean. In the case of one single interaction between institutions $X^{k}$ and $X^{h}$, this implies augmenting the baseline model as follows:

$$
U_{i t}=\sum_{j} \beta_{j} X_{i t}^{j}+\gamma_{k h}\left(X_{i t}^{k}-\bar{X}^{k}\right)\left(X_{i t}^{h}-\bar{X}^{h}\right)+\chi G_{i t}+\alpha_{i}+\lambda_{t}+\varepsilon_{i t}
$$

where $\bar{X}^{k}$ and $\bar{X}^{h}$ are the sample means - across countries and over time - of $X^{k}$ and $X^{h}$, respectively, and other variables are denoted as in equation [1]. With this formulation, coefficient $\beta_{k}$ can be readily interpreted as the marginal unemployment effect of $X^{k}$ at its sample mean $\bar{X}^{k}$, when all other co-variates are kept constant at their sample means. For two institutions $X^{k}$ and $X^{h}$ that increase unemployment $-e . g$. unemployment benefits and the tax wedge in the baseline equation of Table 2, a negative and significant sign for the interaction coefficient $\gamma_{k h}$ would provide evidence of reform complementarity. ${ }^{19}$

Undertaking a systematic analysis of policy interactions within the above framework is not straightforward, however. This is because any extension of equation [2] to more than one type of interaction should also include all "implicit" interactions in order to minimise the risk of coefficient bias (unless there are strong a priori reasons to proceed otherwise, see e.g. Braumoeller, 2004). For example, estimating a model with four couples of multiplicative interactions $\left(X^{k}, X^{h}\right)$, $\left(\mathrm{X}^{k}, \mathrm{X}^{m}\right),\left(\mathrm{X}^{k}, \mathrm{X}^{n}\right)$ and $\left(\mathrm{X}^{k}, \mathrm{X}^{p}\right)$ would in fact imply incorporating a total of 26 interaction terms in the equation - the total number of combinations of two and more variables within a set of five institutions, thereby inducing a substantial loss of degrees of freedom. ${ }^{20}$ Yet, theory suggests that virtually any interaction is possible (see Box 1). For this reason, the analysis of this paper will search for interactions that appear to be robust in simple specifications with only one or two interactions (plus additional "implicit" interactions when appropriate).

One of the most recurrent interactions in the empirical literature on unemployment is between policies and bargaining regimes (Elmeskov et al., 1998; Daveri and Tabellini, 2000). ${ }^{21}$ In particular, some earlier studies find that the effects of the tax wedge and EPL are most detrimental for unemployment in intermediate bargaining regimes, where "insiders" have stronger bargaining power and can more easily resist attempts by employers to transfer the burden of payroll taxes and/or 18 turnover costs onto wages. Here, this issue is reassessed by allowing the slope of 


\section{Box 1. Interactions among policies and institutions in the standard wage setting/price setting model}

In a standard wage setting/price setting (WS PS) model (e.g. Layard et al., 1991; Nickell and Layard, 1999), it can be shown that institutions interact with each other in their impact on aggregate employment and unemployment. Such interactions reflect two groups of mechanisms (Belot and van Ours, 2004):

- First, policies and institutions that affect the elasticity of wage claims to employment (e.g. unemployment benefits, union bargaining power, product market regulation) and/or the elasticity of labour demand to the bargained wage (e.g. product market regulation, EPL, the tax wedge) interact with policies and institutions that shift the level of wage claims (e.g. unemployment benefits) and/or labour demand (e.g. product market regulation). More formally, any factor that affects the slope of the WS and/or PS curves interacts with any factor that affects the level (i.e. the vertical position) of the WS and/or PS curves. For example, the employment effects of a labour market reform that shifts the WS curve downwards (e.g. a cut in unemployment benefits) will be greater: $i$ ) the flatter the PS curve (e.g. the lower the degree of product market regulation), because the decline in real wages induced by the reform has larger effects on labour demand in this case (see the figure below for a graphical illustration); ii) the flatter the WS curve (e.g. the lower the bargaining power of unions and/or the lower the degree of product market regulation), because the increase in employment induced by the reform has smaller feedback effects in terms of higher wage claims.

The more elastic the labour demand, the greater the impact of a labour market reform

Real wage

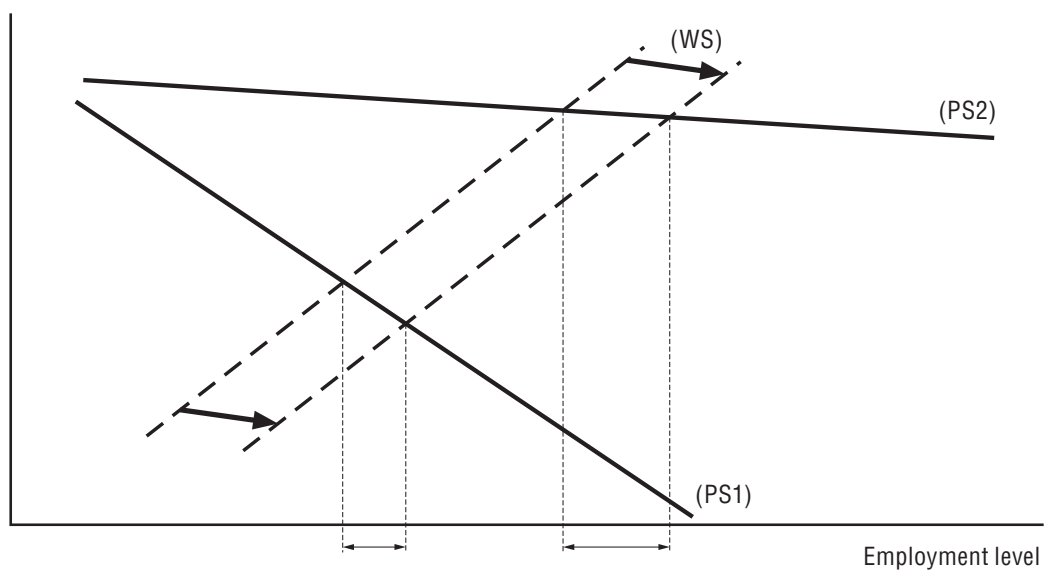




\section{Box 1. Interactions among policies and institutions in the standard wage setting/price setting model (cont.)}

- Second, the marginal impact on labour demand of a given change in real wages is likely to be larger when employment is already high than when it is low. More formally, the labour demand or PS curve is likely to be approximately iso elastic, i.e. convex in the real wage/employment space. As a result, labour market reform that shifts the WS curve downwards (e.g. a cut in unemployment benefits) will be greater the higher the initial level of employment, i.e. the more employment friendly the initial institutional framework (see figure below). This observation has lead a number of researchers to argue that structural reforms are complementary, in the sense that the combined effect of several employment friendly reforms is greater than the sum of the effects of each of them undertaken in isolation (Coe and Snower, 1997; Fitoussi et al., 1998; Orszag and Snower, 1998).

\section{The higher the initial employment level, the greater the impact of a labour market reform}

\section{Real wage}

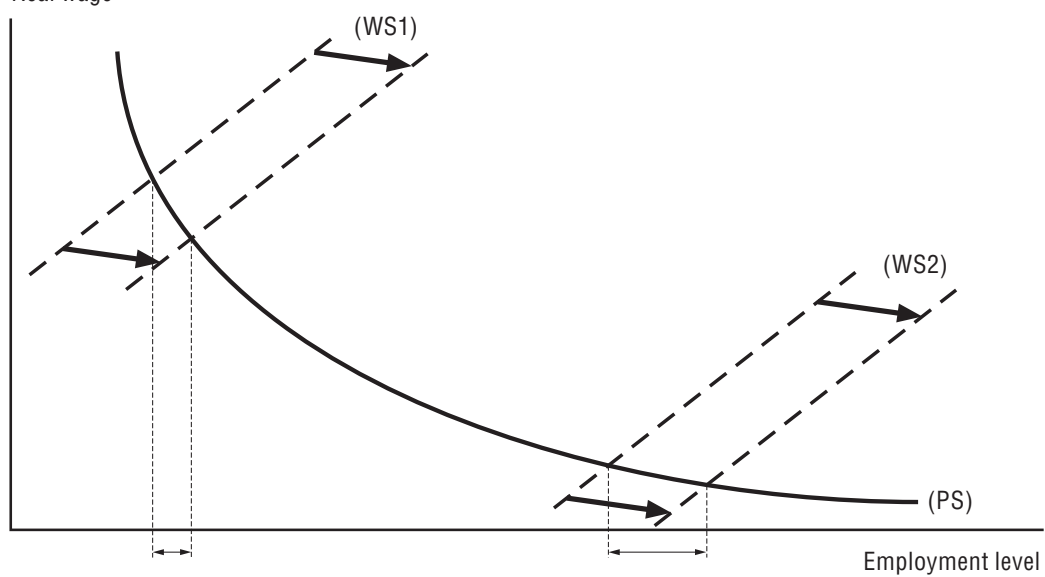

Generally speaking, both of these groups of mechanisms provide theoretical support for the view that reforms are complementary. This may not always be the case, however, because unlike the second type of mechanism, the first one does not unambiguously lead to reform complementarities. For example, a cut in unemployment benefits not only shifts the WS curve downwards but also makes it steeper, reflecting the greater sensitivity of wage claims to overall labour market conditions when the income loss incurred in case of job loss is high. While the downward shift of the WS curve associated with lower unemployment benefits amplifies the impact of other reforms, the steepening of the WS curve has the opposite effect. Therefore, whether the benefit cut and any other reform that shifts the wage curve downwards are complementary in this case depends on the net outcome of these two opposite effects. The answer typically hinges on the parameters of the WS and PS curves, including in particular the degree of convexity of labour demand. 


\section{Box 1. Interactions among policies and institutions in the standard wage setting/price setting model (cont.)}

The overall lesson that emerges from these theoretical considerations is two fold: $i)$ virtually all possible interactions across policies and institutions can affect employment outcomes; and ii) whether such interactions imply reform complementarities should ultimately be assessed on the basis of the empirical evidence.

either the tax wedge or EPL (or both) to vary across three levels of corporatism in the baseline specification. The evidence presented, in Table 2 (columns 1-3), seems to confirm a "hump-shaped" relationship between the impact of the tax wedge and the degree of corporatism. In intermediate bargaining regimes, a 10 percentage point cut in the tax wedge is estimated to reduce unemployment by 2.8 percentage points more than is the case in decentralised regimes. ${ }^{22} \mathrm{By}$ contrast, while a hump-shaped pattern is also found in the case of EPL, it is statistically significant only at the $10 \%$ level (column 2 ). ${ }^{23}$

Care must be exerted in interpreting these results, however. In fact, countries with intermediate bargaining systems form a highly heterogeneous group as far as the unemployment impact of the tax wedge is concerned, with the large detrimental effect being attributable essentially to two countries, namely France and Spain (Table 2, column 4). A similar problem occurs in the case of EPL (Table 2, column 5). ${ }^{24}$

Other interactions have been analysed in the literature, often with contrasting results (see e.g. Elmeskov et al., 1998; IMF, 2003; Belot and van Ours, 2001; Nicoletti and Scarpetta, 2005). Here, a systematic approach is followed. For all possible interactions among pairs of explanatory variables, an augmented version of the baseline specification including only that interaction is estimated. The explanatory variables for which these specifications are tested include not only the policies and institutions used in the baseline specification but also two dummy variables, one for low degrees of corporatism ${ }^{25}$ and another for high levels of collective bargaining coverage..$^{26}$ Only few interactions turn out to be significant in this estimation exercise and, unsurprisingly, the majority of them concern the variables with the strongest direct effects in the baseline equation, namely unemployment benefits and the tax wedge (Table 3, column 1). ${ }^{27}$

Again, however, these results should be interpreted with caution. Omitted interactions might bias coefficient estimates. More precisely, suppose that no interaction exist between an institution $X^{k}$ and another institution $X^{h}$. If $X^{k}$ is correlated with an omitted third variable $X^{s}$ and if $X^{h}$ interacts with $X^{s}$, then the interaction 
Table 2. Simple interactions between institutions and bargaining regimes, 1982-2003

\begin{tabular}{|c|c|c|c|c|c|}
\hline & 1 & 2 & 3 & 4 & 5 \\
\hline & $\begin{array}{l}\text { Interaction } \\
\text { between tax } \\
\text { wedge and } \\
\text { corporatism }\end{array}$ & $\begin{array}{c}\text { Interaction } \\
\text { between EPL } \\
\text { and corporatism }\end{array}$ & $\begin{array}{l}\text { Interaction } \\
\text { between both tax } \\
\text { wedge and EPL } \\
\text { and corporatism }\end{array}$ & $\begin{array}{c}=1 \\
\text { with intermediate } \\
\text { corporatism } \\
\text { broken down } \\
\text { by country }\end{array}$ & $\begin{array}{c}=2 \\
\text { with intermediate } \\
\text { corporatism } \\
\text { broken down } \\
\text { by country }\end{array}$ \\
\hline \multicolumn{6}{|l|}{ Direct effect of institutions: } \\
\hline \multirow[t]{2}{*}{ Average replacement rate } & 0.107 & 0.116 & 0.126 & 0.116 & 0.103 \\
\hline & {$[5.59]^{* * *}$} & {$[5.45]^{* * *}$} & {$[5.90]^{* * *}$} & {$[6.82]^{* * *}$} & {$[4.65]^{* * *}$} \\
\hline \multirow[t]{2}{*}{ Tax wedge } & 0.307 & 0.273 & 0.304 & 0.277 & 0.260 \\
\hline & {$[10.83]^{* * *}$} & {$[9.48]^{* * *}$} & {$[10.82]^{* * *}$} & {$[9.66]^{* * *}$} & {$[8.97]^{* * *}$} \\
\hline \multirow[t]{2}{*}{ Union density } & -0.036 & -0.035 & -0.032 & -0.035 & -0.025 \\
\hline & {$[1.57]$} & {$[1.61]$} & [1.42] & {$[1.60]$} & [1.09] \\
\hline \multirow[t]{2}{*}{ EPL } & -0.538 & -0.360 & -0.402 & -0.303 & -0.814 \\
\hline & [1.59] & {$[1.11]$} & {$[1.17]$} & {$[0.93]$} & {$[2.30]^{* *}$} \\
\hline \multirow[t]{2}{*}{ PMR } & 0.644 & 0.704 & 0.646 & 0.617 & 0.723 \\
\hline & {$[3.20]^{* * *}$} & {$[3.30]^{* * *}$} & {$[3.17]^{* * *}$} & {$[2.98]^{* * *}$} & {$[3.44]^{* * *}$} \\
\hline \multirow[t]{2}{*}{ High corporatism } & -1.280 & -1.522 & -1.714 & -1.653 & -1.506 \\
\hline & {$[3.03]^{* * *}$} & {$[3.70]^{* * *}$} & {$[4.12]^{* * *}$} & {$[3.38]^{* * *}$} & {$[3.62]^{* * *}$} \\
\hline \multicolumn{6}{|l|}{ Interactions between institutions: } \\
\hline \multirow[t]{2}{*}{ Tax wedge ${ }^{*}$ high corporatism } & 0.061 & & 0.132 & 0.086 & \\
\hline & {$[2.00]^{* *}$} & & {$[2.98]^{* * *}$} & {$[2.85]^{* * *}$} & \\
\hline $\begin{array}{l}\text { Tax wedge * intermediate } \\
\text { corporatism }\end{array}$ & $\begin{array}{l}0.278 \\
{[2.61]^{* * *}}\end{array}$ & & $\begin{array}{l}0.287 \\
{[2.60]^{* * *}}\end{array}$ & & \\
\hline \multirow[t]{2}{*}{ EPL ${ }^{*}$ high corporatism } & & 0.030 & -1.092 & & 0.199 \\
\hline & & {$[0.09]$} & {$[2.13]^{* *}$} & & {$[0.59]$} \\
\hline $\begin{array}{l}\text { EPL } * \text { intermediate } \\
\text { corporatism }\end{array}$ & & $\begin{array}{l}1.698 \\
{[1.70]^{*}}\end{array}$ & $\begin{array}{l}0.284 \\
{[0.26]}\end{array}$ & & \\
\hline \multirow[t]{2}{*}{ Tax wedge Sweden } & & & & 0.194 & \\
\hline & & & & {$[2.03]^{* *}$} & \\
\hline \multirow[t]{2}{*}{ Tax wedge Spain } & & & & 1.919 & \\
\hline & & & & {$[4.21]^{* * *}$} & \\
\hline \multirow[t]{2}{*}{ Tax wedge France } & & & & 0.671 & \\
\hline & & & & {$[4.44]^{* * *}$} & \\
\hline \multirow[t]{2}{*}{ Tax wedge Portugal } & & & & -0.321 & \\
\hline & & & & {$[2.62]^{* * *}$} & \\
\hline \multirow[t]{2}{*}{ EPL Sweden } & & & & & 0.126 \\
\hline & & & & & {$[0.07]$} \\
\hline
\end{tabular}


Table 2. Simple interactions between institutions and bargaining regimes, 1982-2003 (cont.)

\begin{tabular}{|c|c|c|c|c|c|}
\hline & 1 & 2 & 3 & 4 & 5 \\
\hline & $\begin{array}{c}\text { Interaction } \\
\text { between tax } \\
\text { wedge and } \\
\text { corporatism }\end{array}$ & $\begin{array}{c}\text { Interaction } \\
\text { between EPL } \\
\text { and corporatism }\end{array}$ & $\begin{array}{l}\text { Interaction } \\
\text { between both tax } \\
\text { wedge and EPL } \\
\text { and corporatism }\end{array}$ & $\begin{array}{c}=1 \\
\text { with intermediate } \\
\text { corporatism } \\
\text { broken down } \\
\text { by country }\end{array}$ & $\begin{array}{c}=2 \\
\text { with intermediate } \\
\text { corporatism } \\
\text { broken down } \\
\text { by country }\end{array}$ \\
\hline \multirow[t]{2}{*}{ EPL Spain } & & & & & 2.597 \\
\hline & & & & & {$[1.60]$} \\
\hline \multirow[t]{2}{*}{ EPL France } & & & & & 7.076 \\
\hline & & & & & {$[3.54]^{* * *}$} \\
\hline \multirow[t]{2}{*}{ EPL Portugal } & & & & & -1.205 \\
\hline & & & & & {$[0.75]$} \\
\hline $\begin{array}{l}\text { Output gap, Time and } \\
\text { country dummies }\end{array}$ & Yes & Yes & Yes & Yes & Yes \\
\hline Observations & 434 & 434 & 434 & 434 & 434 \\
\hline R-squared & 0.98 & 0.98 & 0.98 & 0.98 & 0.98 \\
\hline $\begin{array}{l}\text { Hausman heterogeneity test } \\
\text { (P-value) }\end{array}$ & 0.001 & 0.047 & 0.001 & 0.330 & 0.075 \\
\hline
\end{tabular}

between $X^{k}$ and $X^{h}$ might still appear significant. In the baseline equation, the presence of country fixed effects essentially aims to control for the effect of omitted, approximately time-invariant, institutions that are correlated with both unemployment and the explanatory variables. Consistently, at least some of the estimates of Table 3 are likely to be biased due to the omission of additional interactions with time-invariant variables. ${ }^{28}$ For example, one cannot rule out $a$ priori that the significant positive interaction between unemployment benefits and the tax wedge in fact reflects the positive interaction between each of these policy indicators and a third, omitted determinant of unemployment - e.g. eligibility rules for access to unemployment or other welfare benefits.

To address this issue, two alternative strategies are implemented. First, an instrumental variable (IV) approach is followed, where any interaction $\left(X_{i t}^{k}-\bar{X}^{k}\right)\left(X_{i t}^{h}-\bar{X}^{h}\right)$ is instrumented with $\left(X_{i t}^{k}-\bar{X}_{i}^{k}\right)\left(X_{i t}^{h}-\bar{X}_{i}^{h}\right)$, which is the product of the deviations of $\mathrm{X}^{k}$ and $X^{h}$ from their respective country-specific means. ${ }^{29}$ Second, augmented versions of each OLS specification are estimated, including all interactions of $X^{k}$ and $\mathrm{X}^{h}$ with country-specific fixed effects variables. ${ }^{30}$ Results from both approaches are reported in Table 3, columns 2 and 3, with IV estimates being presented only when the corresponding instrument is found to be acceptable using standard criteria. ${ }^{31}$ Only the negative interaction between the average unemployment benefit replacement rate and union density appears to be robust across all estimation methods. ${ }^{32}$ To the extent that union density can be considered a proxy of union bargaining 
Table 3. Simple interactions across institutions, 1982-2003

\begin{tabular}{|c|c|c|c|c|}
\hline & OLS & $\mathrm{IV}^{1}$ & $\begin{array}{l}\text { F-Test on } \\
\text { instrument }^{2}\end{array}$ & $\begin{array}{c}\text { OLS with } \\
\text { country-specific } \\
\text { variables }{ }^{3}\end{array}$ \\
\hline Average replacement rate ${ }^{*}$ Tax wedge & $0.003^{* * *}$ & $\ldots$ & 0.6 & $-0.023 * * *$ \\
\hline Average replacement rate ${ }^{*}$ Union density & $-0.002 * * *$ & $-0.009 * * *$ & 65.1 & $-0.006^{* * *}$ \\
\hline Average replacement rate ${ }^{*} \mathrm{EPL}$ & $0.023^{*}$ & . & 2.2 & 0.081 \\
\hline Average replacement rate $*$ PMR & 0.008 & . & 3.4 & 0.040 \\
\hline $\begin{array}{l}\text { Average replacement rate }{ }^{*} \text { High collective } \\
\text { bargaining coverage }\end{array}$ & $-0.093^{* * *}$ & $\cdots$ & 0.2 & -0.605 \\
\hline Average replacement rate ${ }^{*}$ High corporatism & -0.009 & 0.042 & 32.7 & -0.042 \\
\hline Average replacement rate ${ }^{*}$ Low corporatism & 0.039 & . & 5.2 & 0.042 \\
\hline Tax wedge ${ }^{*}$ Union density & -0.001 & -0.006 & 27.4 & 0.001 \\
\hline Tax wedge ${ }^{*}$ EPL & 0.009 & . & 0.2 & $-0.512^{* * *}$ \\
\hline Tax wedge ${ }^{*}$ PMR & $0.033^{* * *}$ & -0.045 & 34.1 & 0.022 \\
\hline $\begin{array}{l}\text { Tax wedge }{ }^{*} \text { High collective bargaining } \\
\text { coverage }\end{array}$ & $0.234^{* * *}$ & -0.093 & 58.6 & $-0.236^{*}$ \\
\hline Tax wedge ${ }^{*}$ High corporatism & $0.050^{*}$ & 0.037 & 30.0 & $-0.335^{* * *}$ \\
\hline Tax wedge ${ }^{*}$ Low corporatism & $-0.072 * *$ & -0.042 & 23.0 & $0.335^{* * *}$ \\
\hline Union density ${ }^{*}$ EPL & -0.004 & -0.004 & 16.2 & $-0.362 * *$ \\
\hline Union density * PMR & -0.004 & 0.023 & 13.0 & $-0.040^{* *}$ \\
\hline Union density ${ }^{*}$ High corporatism & -0.013 & $0.164^{* * *}$ & 159.8 & 0.115 \\
\hline Union density ${ }^{*}$ low corporatism & -0.025 & $-0.215^{* * *}$ & 56.7 & -0.115 \\
\hline EPL $*$ PMR & -0.111 & $-1.076^{* *}$ & 17.3 & -0.272 \\
\hline EPL ${ }^{*}$ High collective bargaining coverage & 1.142 & -0.211 & 502.5 & 4.632 \\
\hline EPL ${ }^{*}$ High corporatism & -0.150 & . & 9.6 & -1.365 \\
\hline EPL ${ }^{*}$ Low corporatism & -0.176 & . & 5.5 & $2.401^{* *}$ \\
\hline PMR * High collective bargaining coverage & 0.168 & 0.212 & 43.4 & -0.623 \\
\hline PMR * High corporatism & $-0.410 * *$ & . & 3.2 & 0.301 \\
\hline PMR * Low corporatism & 0.143 & . & 0.0 & -0.301 \\
\hline
\end{tabular}

The table reports the interaction cofficients from the baseline specification augmented by one interaction at a time.

..: IV estimates are not reported when the instrument is weak according to the Stock-Staiger rule $(\mathrm{F}<10)$.

Estimates of interactions among dichotomic variables as well as between union density and high collective bargaining coverage are not shown.

$*,{ }^{* *},{ }^{* * *}$ statistically significant at the $10 \%, 5 \%$ and $1 \%$ levels, respectively.

1. 2SLS estimates. Any interaction $\mathrm{X}^{*} \mathrm{Y}$ is instrumented with the product of the deviations of $\mathrm{X}$ and $\mathrm{Y}$ from their countryspecific means.

2. F-test statistic on the significance of the instrument in the first-stage regression.

3. For any interaction $\mathrm{X}^{*} \mathrm{Y}$, the specification is augmented by the interactions of both $\mathrm{X}$ and $\mathrm{Y}$ with the fixed effects and estimated by OLS.

Source: Authors' estimates on the basis of data sources described in Annex 2.

power, this finding might reflect the fact that, in most theoretical models, lower bargaining power makes wage claims less responsive to unemployment conditions (see Box 1). Given that union density has no significant direct unemployment effect 
at the sample mean, ${ }^{33}$ the estimates presented in Table 4 imply that, for a country with average values of all institutions, a 10 percentage point reduction in union density can increase the elasticity of unemployment to a benefit cut by $15 \%$ to $75 \%$. For instance, a simultaneous reduction of the average benefit replacement rate and union density by 10 percentage points would lower unemployment by between 1.4 and 2.1 percentage points in the average country (depending on the estimates), against 1.2 percentage points only if union density remains stable.

While a number of specific interactions across policies and institutions have been singled out by previous literature, the systematic econometric analysis undertaken in this section actually suggests that no firm conclusions can be drawn as regards their robustness. This reflects three main factors. First, while theory clearly suggests that all interactions are possible and should therefore be studied simultaneously, this is not feasible in practice using a general model due to the small sample size. ${ }^{34}$ Second, certain interactions - e.g. between the tax wedge and EPL on the one hand and wage bargaining regimes on the other - appear to reflect particular country experiences and cannot easily be generalised. Finally, the majority of apparently significant interactions become insignificant or even change sign when allowance is made for possible correlations between institutions and other, omitted time-invariant determinants of unemployment. This latter result points to the importance of interactions with a number of policies and institutions which are not considered in this section for lack of available data at an annual frequency and/or endogeneity problems. To a limited extent, these additional policy issues are addressed in the next section.

\section{ADDITIONAL DETERMINANTS OF UNEMPLOYMENT PATTERNS}

The first two sections above follow the standard approach of excluding from the baseline specification those policies (such as housing policy, minimum wage and active labour market policies - ALMPs) that require specific econometric treatments and are, therefore, usually not included in general macroeconomic studies of institutional determinants of unemployment (see Annex 1). In particular, i) data on housing policy and home-ownership are scattered and available essentially in cross-section; ii) reliable minimum wage time series exist only for countries where minimum wages are statutory; and iii) measures of ALMP intensity are available only since 1985 and are likely to be endogenous to unemployment by construction. The strategy followed above does not intend to downplay the importance of these factors. Their impact on unemployment is therefore analysed in this section, through case-by-case adaptation of the general approach set forth above.

\section{Housing policy and home ownership}

A growing body of literature has been focussing recently on the relationship between housing policy, home ownership and job mobility. However, cross-country 
comparable data on transaction costs and housing policies are scattered, while home ownership data are available only for period-averages. ${ }^{35}$ Still, one way to shed some light on the relationship between home ownership and unemployment, while controlling simultaneously for the effects of other time-varying institutional factors, is to look at the simple cross-country correlation between country fixed effects from the baseline specification and the rate of home ownership (defined here as owner-occupied housing as a percentage of total occupied housing stock). As shown in Figure 2, this correlation is indeed high: more than one-third of the variance among fixed effects appears to be explained by the average rate of home ownership during the 1990s. This finding is in line with most existing macroeconomic studies (e.g. Oswald, 1997, Cameron and Muellbauer, 1998, Green and Hendershott, 2001, Nickell et al., 2005).

Care must be exerted, however, in drawing policy conclusions from this result. In fact, home ownership might be endogenous insofar as, ceteris paribus, societies with lower degrees of internal and external migration are likely to have higher rates of home ownership. From a policy perspective, it is indeed crucial to determine whether high rates of home ownership induce high unemployment by preventing mobility or whether more mobile labour forces bring about simultaneously

Figure 2. Country fixed effects from the baseline unemployment regression and rates of home ownership ${ }^{1}$

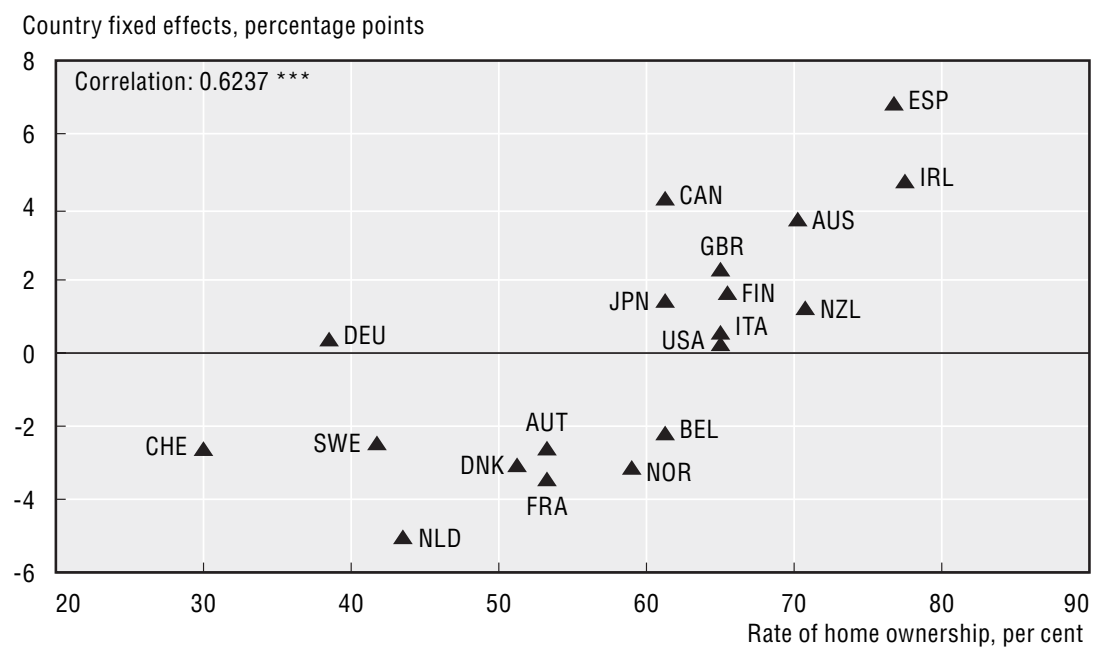

*** Statistically significant at the $1 \%$ level.

1. Country fixed effects are taken from the unemployment rate equation in Table 1, column 1. In the case of Finland, Germany and Sweden, they refer to the period 1993-2003 (as opposed to 1982-2003 for other countries). Rates of home ownership are averages over the period 1990-2000 (for sources and methodological details, see Annex 2).

26 Source: Authors' estimates on the basis of data sources described in Annex 2. 
low home ownership rates and better labour market outcomes. Disentangling these different links is, however, impossible with the data at hand.

\section{Minimum wages}

The natural approach to study the impact of the minimum wage on unemployment is to augment the set of explanatory variables in the baseline specification (equation [1]) with a measure of the minimum wage that is comparable across countries. While the most frequent approach is to use the ratio of gross statutory minimum wages to median or average wages (see e.g. OECD, 1998; Elmeskov et al., 1998), a few papers combine information on both statutory and contractual minimum wages (e.g. Neumark and Wascher, 1999). However, the latter can vary substantially across sectors and often depend on workers' age, experience and qualifications. Such detailed information is rarely available and, in any event, is inherently hard to summarise in a single, cross-country comparable indicator. In addition, the employment effects of negotiated minima are likely to be quite different from those of a uniform national minimum wage. For these reasons, following the main thrust of the literature, collectively-bargained minima are excluded from the scope of this analysis. However, the main drawback of focussing on statutory minima - measured here as a percentage of median wages - is that the estimation sample is halved. ${ }^{36}$

Table 4 presents the outcome of this regression exercise. Consistent with previous OECD work (OECD, 1998, Elmeskov et al., 1998), no significant direct impact of the minimum wage on the unemployment rate is found (column 1), ${ }^{37}$ except when controls for the output gap are omitted (column 2). This latter result can be explained by the pro-cyclicality of median wages, which makes the ratio of minimum to median wages highly endogenous in the absence of a good control for the business cycle. Consistent with this interpretation, no significant impact of the minimum wage is estimated if measures of macroeconomic shocks such as those used in Table 1 are substituted for the output gap in the specification (not reported in Table 4). Conversely, and in line with theoretical priors, additional estimates suggest that a high tax wedge has more adverse effects on unemployment when the minimum wage is high (columns 3 and 4).$^{38}$ The estimated impact of the minimum wage on the elasticity of unemployment to the tax wedge is large. Taken at face value, the estimates reported in columns 3 and 4 suggest that an increase in the ratio of minimum to median wages by 10 percentage points ${ }^{39}$ would increase the impact of the tax wedge on unemployment by about $50 \%$ in the "average" OECD country.

\section{Active labour market policies}

Most macroeconometric studies use ALMP expenditures per unemployed person as an indicator of countries' spending efforts in pursuing active policies. This indicator is expressed as a percentage of GDP per capita to ensure cross-country comparability (e.g. Scarpetta, 1996; Nickell, 1997, 1998; Nickell and Layard, 1999; 
Table 4. Unemployment effects of statutory minimum wages, 1982-2003

\begin{tabular}{|c|c|c|c|c|}
\hline & 1 & 2 & 3 & 4 \\
\hline & $\begin{array}{l}\text { Baseline equation } \\
\text { augmented with } \\
\text { minimum wage }\end{array}$ & $\begin{array}{l}\quad=1 \\
\text { without output } \\
\quad \text { gap }\end{array}$ & $\begin{array}{l}\quad=1 \\
\text { with tax wedge } \\
\text { interacted with } \\
\text { minimum wage }\end{array}$ & $\begin{array}{l}\quad=3 \\
\text { with instrumented } \\
\text { interaction }\end{array}$ \\
\hline \multicolumn{5}{|c|}{ Direct effect of policies/institutions: } \\
\hline \multirow[t]{2}{*}{ Average replacement rate } & 0.095 & 0.101 & 0.091 & 0.090 \\
\hline & {$[2.52]^{* *}$} & {$[2.82]^{* * *}$} & {$[2.43]^{* *}$} & {$[2.39]^{* *}$} \\
\hline \multirow[t]{2}{*}{ Tax wedge } & 0.236 & 0.250 & 0.237 & 0.237 \\
\hline & {$[5.66]^{* * *}$} & {$[4.40]^{* * *}$} & {$[6.63]^{* * *}$} & {$[6.62]^{* * *}$} \\
\hline \multirow[t]{2}{*}{ Union density } & -0.047 & 0.011 & -0.048 & -0.048 \\
\hline & {$[1.65]$} & {$[0.37]$} & {$[1.66]^{*}$} & {$[1.65]^{*}$} \\
\hline \multirow[t]{2}{*}{ EPL } & 0.013 & -0.892 & -0.566 & -0.746 \\
\hline & {$[0.03]$} & {$[1.56]$} & {$[1.14]$} & [1.32] \\
\hline \multirow[t]{2}{*}{ PMR } & 0.847 & 1.158 & 0.562 & 0.473 \\
\hline & {$[3.13]^{* * *}$} & {$[3.40]^{* * *}$} & {$[2.16]^{* *}$} & {$[1.52]$} \\
\hline \multirow[t]{2}{*}{ High corporatism } & -1.764 & -2.826 & -1.645 & -1.608 \\
\hline & {$[2.66]^{* * *}$} & {$[3.32]^{* * *}$} & {$[2.49]^{* *}$} & {$[2.40]^{* *}$} \\
\hline \multirow[t]{2}{*}{ Minimum wage $^{1}$} & -0.048 & 0.113 & 0.029 & 0.052 \\
\hline & {$[1.30]$} & {$[2.31]^{* *}$} & {$[0.72]$} & {$[0.94]$} \\
\hline \multicolumn{5}{|c|}{ Interactions between policies/institutions: } \\
\hline \multirow[t]{2}{*}{ Tax wedge ${ }^{*}$ Minimum wage } & & & 0.011 & 0.015 \\
\hline & & & {$[4.12]^{* * *}$} & {$[2.35]^{* *}$} \\
\hline F-test on instrument ${ }^{3}$ & & & & 23.16 \\
\hline Country dummies & Yes & Yes & Yes & Yes \\
\hline Time dummies & Yes & Yes & Yes & Yes \\
\hline Output gap & Yes & No & Yes & Yes \\
\hline Observations & 217 & 217 & 217 & 217 \\
\hline R-squared & 0.98 & 0.98 & 0.98 & 0.92 \\
\hline \multicolumn{5}{|c|}{$\begin{array}{l}\text { 1. The minimum wage is measured as the ratio of the legal minimum wage to the median wage (for details, } \\
\text { see Annex 2). }\end{array}$} \\
\hline \multicolumn{5}{|c|}{$\begin{array}{l}\text { 2. The equation is estimated by two-stage least squares where the interaction between the tax wedge and the mini- } \\
\text { mum wage is instrumented with the product of the deviations of the tax wedge and the minimum wage from their } \\
\text { respective country-specific means. }\end{array}$} \\
\hline \multicolumn{5}{|c|}{ 3. F-test statistic on the significance of the instrument in the first-stage regression. } \\
\hline
\end{tabular}

Boone and van Ours, 2004). Since ALMP expenditures are unlikely to vary in proportion to changes in unemployment, such a synthetic indicator of ALMP spending is likely to be pro-cyclical, i.e. it declines (rises) when unemployment goes up (down). 
The resulting endogeneity bias has typically been addressed in the literature by instrumenting the ALMP spending indicator by its country average and by estimating the unemployment equation using random country effects. However, such an approach is likely to yield inconsistent estimates, as it rests on the implausible assumption that country effects are independent from other co-variates. One alternative approach is to look at the simple correlation between country averages of ALMP spending and country fixed effects from panel data unemployment regressions. Consistent with most available studies, average ALMP expenditures per unemployed as a percentage of GDP per capita are found to be significantly correlated with country fixed effects obtained from the baseline specification (Figure 3). However, as in the case of home ownership discussed above, this finding cannot be readily interpreted as a causal relationship between ALMP spending and aggregate unemployment.

A more ambitious approach is to use instrumental variable (IV) techniques to re-estimate the baseline fixed-effect specification (Table 1, column 1) augmented with the synthetic indicator of ALMP. Here, the retained instrument is the lagged first difference of the residual of the regression of the ALMP indicator on current and lagged values of the output gap. ${ }^{40}$ While the non-instrumented regression yields a significant effect of ALMP spending (Table 5, column 1), the coefficient

\section{Figure 3. Country fixed effects from the baseline unemployment regression and ALMP spending ${ }^{1}$}

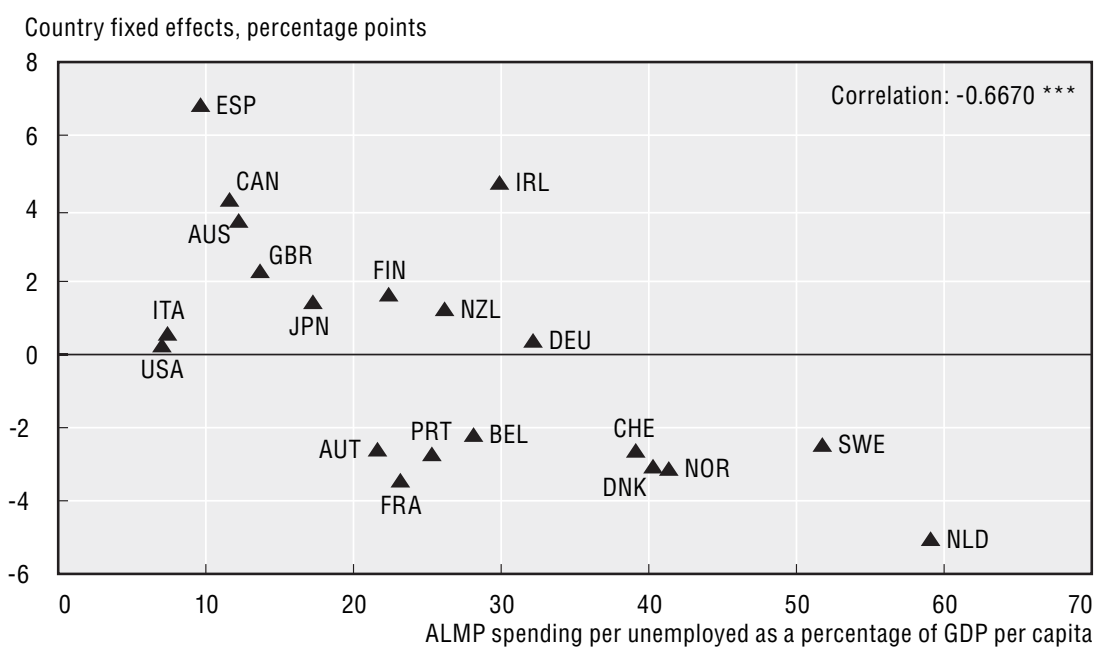

*** Statistically significant at the $1 \%$ level.

1. Country fixed effects are taken from the unemployment rate equation in Table 1, column 1. In the case of Finland, Germany and Sweden, they refer to the period 1993-2003 (as opposed to 1982-2003 for other countries). Rates of home ownership are averages over the period 1990-2000 (for sources and methodological details, see Annex 2). 
Table 5. Active labour market policies, 1985-2002

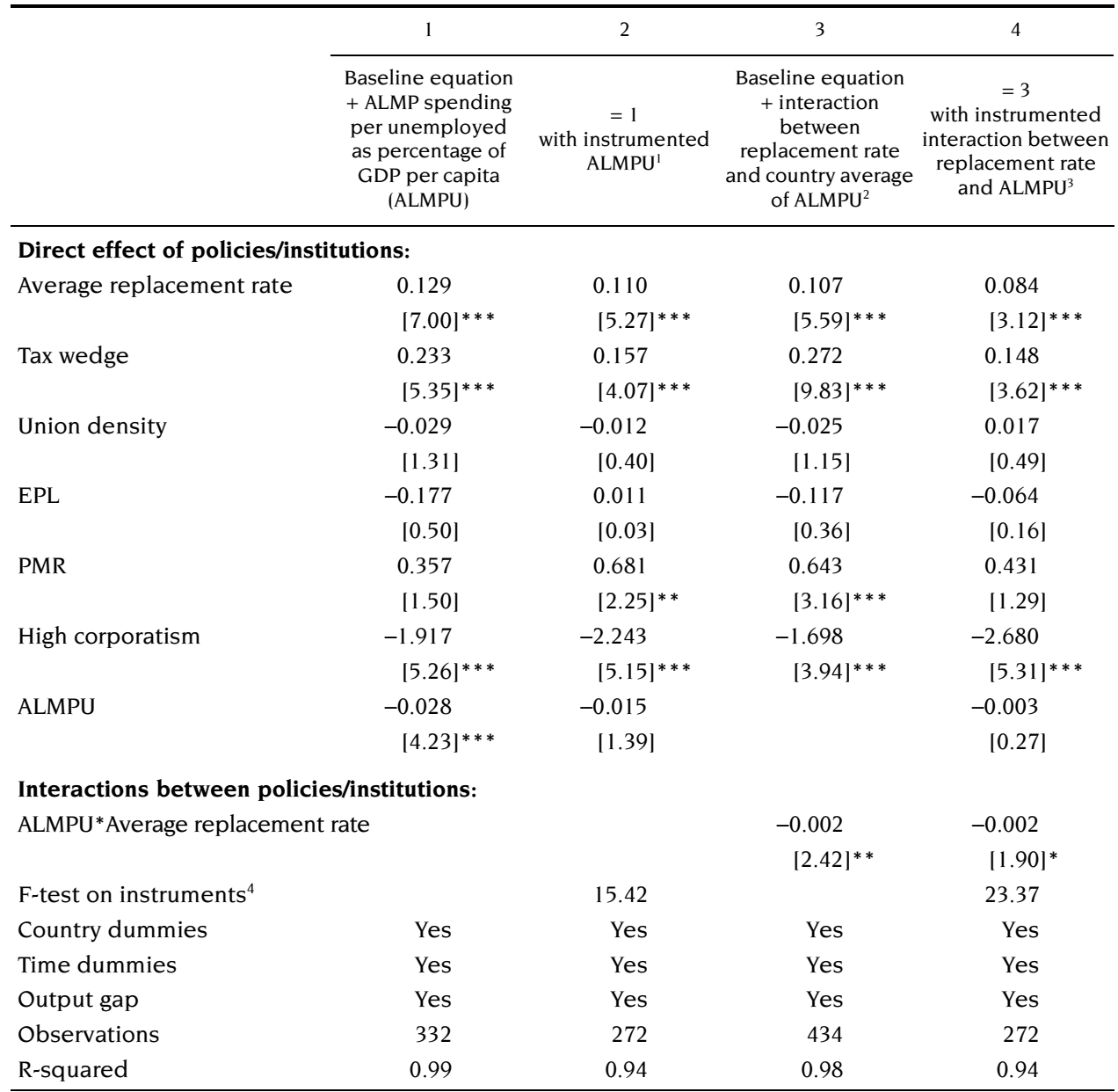

Absolute value of $\mathrm{t}$ statistics in brackets.

$*, * *, * * *$ statistically significant at the $10 \%, 5 \%$ and $1 \%$ levels, respectively.

1. 2SLS; ALMPU is instrumented with the lagged first difference of the residual of a regression of ALMPU on up to three lags of the output gap.

2. The baseline equation is augmented with the interaction of the average replacement rate with the country-specific average of ALMPU, both expressed as deviations from their sample averages.

3. 2SLS; ALMPU is instrumented with the lagged first difference of the residual of a regression of ALMPU on up to three lags of the output gap; the interaction Replacement rate*ALMPU is instrumented with the product of the deviation of the replacement rate from its country-specific means and the lagged first difference of the residual of a regression of ALMPU on up to three lags of the output gap.

4. F-test statistic on the significance of the instruments in the first-stage regression.

Source: Authors' estimates on the basis of data sources described in Annex 2. 
becomes insignificant in the IV approach (column 2). While this finding could be interpreted as evidence against any significant effects of total ALMP spending on unemployment, it could also reflect the low efficiency of two-stage least squares estimators or, as explored in detail below, the heterogeneity of ALMP programmes that are included in the aggregate spending indicator.

A related issue is whether ALMP expenditures can mitigate the detrimental unemployment effects of high unemployment benefits. This could be the case mainly for two reasons (Boone and Van Ours, 2004). First, long-term oriented programmes, such as training programmes, are designed to reduce the risk of future unemployment spells by improving workers' competencies and reducing mismatch. Thus, high benefit replacement rates might be complementary to these programmes insofar as they reduce trainees' incentives to accept offers for unstable jobs before programme completion. Second, besides facilitating job-search, ALMPs can be used for the purpose of "activation" and are thus likely to motivate job-search as some benefit recipients seek to avoid complying with unpleasant programme requirements. This latter effect is likely to be greater, the higher the level of unemployment benefits with respect to the wage level of potential job offers. Indeed, the literature on programme evaluation has shown that careful integration of active and passive policies can be effective in reducing disincentives effects brought about by generous unemployment benefits (OECD, 2005).

The last two columns of Table 5 shed some light on this interaction by using two different methods. In column 3, following Boone and van Ours (2004), the baseline unemployment regression is augmented with the interaction between the average benefit replacement rate and country-specific averages of the synthetic measure of ALMP spending. These estimates, however, potentially suffer from the omitted interaction bias discussed in the second section. Therefore, following the approach developed earlier, IV estimates of this interaction are obtained by exploiting the time-series variation of the ALMP indicator (Table 5, column 4). ${ }^{41}$ The estimated coefficient of the interaction is robust across methods and suggests that the adverse impact of unemployment benefits is lower in countries that spend more on ALMPs. Taken at face value, these estimates suggest that the unemployment effect of the generosity of unemployment insurance becomes statistically insignificant in high ALMP countries, such as Denmark or the Netherlands. ${ }^{42}$

Table 6 proceeds with a disaggregated analysis of the unemployment effects of ALMP expenditures. Concretely, the synthetic indicator of ALMP spending is decomposed into the five main categories available in the OECD Labour Market Policies database: public employment services (PES) and administration; training programmes; youth measures; subsidized employment; and measures for the disabled (for details, see Annex 2). 
Table 6. Categories of active labour market policies, 1985-2002

\begin{tabular}{|c|c|c|c|c|c|c|c|}
\hline & 1 & 2 & 3 & 4 & 6 & 5 & 7 \\
\hline & $\begin{array}{c}\text { Baseline } \\
\text { equation } \\
+ \text { ALMP } \\
\text { spending per } \\
\text { unemployed } \\
\text { by category } \\
\text { as percentage } \\
\text { of GDP per } \\
\text { capita }\end{array}$ & $\begin{array}{c}=1 \\
\text { with } \\
\text { instrumented } \\
\text { ALMP } \\
\text { variables }{ }^{1}\end{array}$ & $\begin{array}{c}\text { Baseline } \\
\text { equation } \\
+ \text { ALMP } \\
\text { spending } \\
\text { by category } \\
\text { as } \\
\text { percentage } \\
\text { of GDP² }\end{array}$ & $\begin{array}{c}\text { Baseline } \\
\text { equation } \\
+ \text { training } \\
\text { spending per } \\
\text { unemployed } \\
\text { as } \\
\text { percentage } \\
\text { of GDP per } \\
\text { capita }\end{array}$ & $\begin{array}{l}\quad=4 \\
\text { with } \\
\text { instrumented } \\
\text { training }\end{array}$ & $\begin{array}{c}\text { Baseline } \\
\text { equation } \\
+ \text { training } \\
\text { spending } \\
\text { as } \\
\text { percentage } \\
\text { of GDP }\end{array}$ & $\begin{array}{c}=4 \\
\text { estimated } \\
\text { by System } \\
\text { GMMs }^{3}\end{array}$ \\
\hline \multicolumn{8}{|c|}{ Direct effect of ALMP categories: } \\
\hline Training & $\begin{array}{l}-0.078 \\
{[4.92]^{* * *}}\end{array}$ & $\begin{array}{l}-0.189 \\
{[3.36]^{* * *}}\end{array}$ & $\begin{array}{r}-0.058 \\
{[2.17]^{* *}}\end{array}$ & $\begin{array}{l}-0.086 \\
{[5.58]^{* * *}}\end{array}$ & $\begin{array}{l}-0.158 \\
{[4.32]^{* * *}}\end{array}$ & $\begin{array}{c}-0.053 \\
{[1.70]^{*}}\end{array}$ & $\begin{array}{l}-0.124 \\
{[2.08]^{* *}}\end{array}$ \\
\hline PES & $\begin{array}{l}-0.149 \\
{[3.17]^{* * *}}\end{array}$ & $\begin{array}{r}-0.044 \\
{[0.48]}\end{array}$ & $\begin{array}{l}0.184 \\
{[2.63]^{* * *}}\end{array}$ & & & & \\
\hline Youth measures & $\begin{array}{l}0.056 \\
{[1.44]}\end{array}$ & $\begin{array}{l}0.095 \\
{[0.83]}\end{array}$ & $\begin{array}{l}0.287 \\
{[5.61]^{* * *}}\end{array}$ & & & & \\
\hline $\begin{array}{l}\text { Subsidised employ- } \\
\text { ment }\end{array}$ & $\begin{array}{r}-0.025 \\
{[1.31]}\end{array}$ & $\begin{array}{l}0.023 \\
{[0.28]}\end{array}$ & $\begin{array}{r}-0.034 \\
{[1.40]}\end{array}$ & & & & \\
\hline Measures for disabled & $\begin{array}{l}0.054 \\
{[3.16]^{* * *}}\end{array}$ & $\begin{array}{l}0.064 \\
{[1.43]}\end{array}$ & $\begin{array}{l}0.200 \\
{[4.98]^{* * *}}\end{array}$ & & & & \\
\hline F-test on instrument ${ }^{4}$ & & 10.32 & & & 22.19 & & \\
\hline Hansen test (P-value) & & & & & & & 1.00 \\
\hline Arellano-Bond AR1 test & & & & & & & $-2.39 * *$ \\
\hline Arellano-Bond AR2 test & & & & & & & $-1.86^{*}$ \\
\hline Baseline controls ${ }^{5}$ & Yes & Yes & Yes & Yes & Yes & Yes & Yes \\
\hline Country dummies & Yes & Yes & Yes & Yes & Yes & Yes & No \\
\hline Time dummies & Yes & Yes & Yes & Yes & Yes & Yes & Yes \\
\hline Output gap & Yes & Yes & Yes & Yes & Yes & Yes & Yes \\
\hline Observations & 324 & 266 & 324 & 324 & 266 & 324 & 298 \\
\hline R-squared & 0.99 & 0.94 & 0.99 & 0.99 & 0.94 & 0.99 & \\
\hline
\end{tabular}

Absolute value of $\mathrm{t}$ statistics in brackets.

$*, * *, * * *$ statistically significant at the $10 \%, 5 \%$ and $1 \%$ levels, respectively.

1. 2SLS estimates. ALMP variables are instrumented with the lagged first difference of the residual of their regression on up to three lags of the output gap.

2. To facilitate the comparison with other columns, ALMP spending / GDP is devided by the sample average of the ratio of unemployment to population.

3. One-step GMM-SYS robust estimates. The error term is modeled as an ARMA process with an AR(1) component. Training and output gap are treated as endogenous variables. The common factor restriction is not imposed. Only long-run effects are presented. Unemployment rate, training and output gap dated t-2, t-3 and t- 4 are used as instruments in the difference equation. First differences of unemployment rate, training and output gap dated $\mathrm{t}-1$ are used as instruments in the level equation. The Hansen-Sargan statistic provides a test of overidentifying restrictions. The model is rejected if the statistic is significant. Arellano-Bond statistics test the autocorrelation of the first difference of the residuals at order 1 and 2 and are normally distributed under the null. The model is rejected if evidence of autocorrelation is found at order 2 .

4. F-test statistic on the significance of the instruments in the first-stage regression.

5. Baseline controls are: average benefit replacement rate, tax wedge, union density, EPL, PMR, and a dummy for high corporatism.

Source: Authors' estimates on the basis of data sources described in Annex 2. 
Columns 1-3 of Table 6 report estimates of specifications including all five categories. Column 1 reports fixed-effects estimates and column 2 IV estimates. In addition, column 3 reports fixed-effects estimates obtained by substituting ALMP spending as a percentage of GDP to ALMP expenditure per unemployed person as a percentage of GDP per capita, as suggested by Estevao (2003). Given that, ceteris paribus, ALMP spending rises and GDP declines with an increase in unemployment, the estimated coefficient of ALMP spending as a percentage of GDP is unambiguously upward biased. If negative and significant, however, its estimate would then provide a lower bound (in absolute terms) for the true effect of ALMPs. Consistent with Boone and van Ours (2004), labour market training is the only ALMP category whose negative coefficient appears to be robust across all three estimation methods. The statistical significance of ALMP spending on training programmes is also found to be robust to the exclusion of other ALMP categories from the estimated equation (columns 4-6), as well as to system GMMs estimation, where ALMP and the output gap are assumed to be endogenous (column 7). ${ }^{43}$ Since lower bound estimates (columns 3 and 6) are significant in the case of training, it is possible to conclude that, for the average OECD country, increasing ALMP spending on training programmes per unemployed as a percentage of GDP per capita by 4 percentage points ${ }^{44}$ would reduce unemployment by at least 0.2 percentage point. This value increases to 0.6 percentage point if simulations are based on IV or GMM estimates.

These results provide some additional insight on the role of ALMPs in curbing unemployment ${ }^{45}$ and can be seen as complementary to microeconometric studies. In fact, general equilibrium and long-run effects can hardly be taken into account in practice in micro-evaluation studies. The consequence is that those studies might tend to be overly optimistic as regards programmes involving large potential substitution effects (e.g. subsidised employment) as well as overly pessimistic on programmes that are likely to pay off only in the long-run (e.g. training programmes).

\section{INTERACTIONS BETWEEN INSTITUTIONS AND SHOCKS}

It has recently been argued that the current degree of heterogeneity in policies and institutions across OECD countries largely pre-dates - and is therefore unable to account for - cross-country trends in unemployment performance since the early 1970s (Blanchard and Wolfers, 2000). The evidence presented in the previous sections yields no support for this view, insofar as a sizeable share of the cross-country variation of unemployment changes between 1982 and 2003 can be explained by a model considering only institutions and the output gap. Still, besides permanent effects, policies and institutions may also have had a temporary but persistent impact on unemployment during the past three decades via their interaction with the series of adverse macroeconomic shocks which have hit 
OECD countries, including oil price shocks, real interest rate shocks and the slowdown in the pace of technological progress. ${ }^{46}$ The purpose of this section is to investigate these interactions between institutions and shocks.

There are a number of potential channels through which cross-country differences in policy settings may lead to divergent employment outcomes in the face of common shocks. In particular, many of the policies and institutions that have been put forward as explanations for high structural unemployment may also increase unemployment persistence. For instance, by protecting labour market "insiders" from the risk of income loss, high unemployment benefits and/or strict EPL can reduce the sensitivity of wages to general economic conditions, thereby preventing a swift adjustment of unemployment back to its initial level in the aftermath of a shock (see e.g. Blanchard, 1999). Increased "economic turbulence" e.g. greater skill losses of laid-off workers due to skilled-biased technological progress, or more frequent reallocation of production factors across industries may even lead to a permanent increase in unemployment in the presence of high unemployment benefits, as wages of laid-off workers fail to adjust to less favourable market conditions (Ljungqvist and Sargent, 1998). ${ }^{47}$ Moreover, strict PMR can further increase unemployment persistence by making labour demand less sensitive to wages. By contrast, certain categories of ALMPs such as job-search assistance can increase the influence of labour market "outsiders" - including the longterm unemployed, youth and/or certain groups of female workers - in wage determination and thus reduce wage and unemployment persistence. A high degree of centralisation and/or co-ordination of wage bargaining may also speed up wage adjustment to adverse shocks at the aggregate level. Other relevant structural settings, which are not covered below but have been studied in previous work, include notably competition in financial markets. ${ }^{48}$

Recent empirical evidence ${ }^{49}$ points to cross-country differences in the resilience of output and employment to shocks - most prominently between the United States and Continental European countries, and previous work suggests that structural policy settings seem to matter in this respect. ${ }^{50}$ These findings are consistent with the empirical literature indicating that interactions between institutions and shocks have contributed to shape employment patterns over the past decades. ${ }^{51}$ In their seminal paper, Blanchard and Wolfers (2000) find that interactions between time-invariant labour market policies and institutions - as measured by country averages of the corresponding indicators over the period 1960-1995 - and macroeconomic shocks have played a crucial role in explaining the rising dispersion of unemployment rates in OECD countries over time..$^{52}$ However, no allowance is made in their analysis for the direct impact of changes in institutions, which casts some doubts on the magnitude of the estimated effects. Addressing this issue, two other recent studies which attempt to disentangle the 34 roles played by institutions and interactions between institutions and shocks 
conclude that direct effects clearly dominate (Nickell et al., 2005; Nunziata, 2002). Also, as already noted, the fact that the unemployment regressions presented in the previous sections account for a significant share of unemployment trends over the period $1982-2003^{53}$ is consistent with the view that interactions between institutions and shocks are likely to provide only a complementary explanation for the evolution of unemployment.

\section{Unobserved shocks}

This section reports the results of a panel data econometric study of the unemployment effects of interactions between institutions and shocks. Ideally, the analysis should cover a lengthy time span encompassing in particular the major oil and real interest rate shocks of the 1970s and early 1980s. However, some of the OECD policy and institutional indicators are available only over shorter periods, e.g. EPL and the tax wedge since 1982 and 1979, respectively. In order to get around this difficulty, country averages of the indicators are computed over the longest available periods and are then interacted with time-varying measures of macroeconomic shocks. ${ }^{54}$ This approach is in line with other recent empirical work in the field and has been shown to yield more stable results than when time-varying policy indicators are used (Blanchard and Wolfers, 2000). Another side benefit of the approach is to allow the use of the OECD estimate of collective bargaining coverage - which is available only for three years, 1980, 1990 and 2000 - instead of union density in order to better capture the actual strength of unions in wage bargaining..$^{55}$ Also, an analysis of variance on these data shows that the variation in policies and institutions across countries outweighs their variation over time, at least over the sample considered. This suggests that only a limited amount of information is lost by omitting the time-series dimension of policy indicators when the latter are used in interaction terms. ${ }^{56}$

The analysis proceeds with the estimation by non-linear least squares of a simple unemployment equation with interactions between time-invariant institutions and unobserved shocks over 1970-2003, in the spirit of Blanchard-Wolfers (2000):

$$
U_{i t}=\lambda_{t}\left(1+\sum_{j} \gamma_{j}\left(\bar{X}_{i}^{j}-\bar{X}^{j}\right)\right)+\alpha_{i}+\varepsilon_{i t}
$$

where $\bar{X}_{i}^{j}$ is the country average of policy indicator $\mathrm{X}^{i}$ for country i over the longest available period, ${ }^{57} \bar{X}^{j}$ is the sample average of policy indicator $X^{i 58}$ and $\lambda_{t}$ is a time dummy variable which is assumed to capture an undefined set of shocks that are common to all countries. ${ }^{59}$ However, one cannot safely estimate equation [3] with the full set of time-invariant institutions as explanatory variables, due to multicollinearity problems. Multicollinearity arises from the high (cross-country) correlation which exists between several of the policy indicators used as explanatory variables (Box 2). 


\section{Box 2. Cross-country correlation of policies and institutions: evidence and consequences for econometric analysis}

Cross-country correlations between the various policy and institutional indicators used throughout this paper are usually high. For instance, as shown in the table below, those countries that have strict (lax) EPL also tend to have high (low) tax wedges and a high (low) share of workers covered by collective agreements.

\section{Cross-country correlation between country means of institutional indicators}

Correlation coefficients

\begin{tabular}{lccccc}
\hline & $\begin{array}{c}\text { Replacement } \\
\text { rate }\end{array}$ & $\begin{array}{c}\text { Tax } \\
\text { wedge }\end{array}$ & $\begin{array}{c}\text { Collective } \\
\text { bargaining } \\
\text { coverage }\end{array}$ & EPL & $\begin{array}{c}\text { PMR } \\
\text { (time varying) corporatism }\end{array}$ \\
\hline $\begin{array}{l}\text { Replacement rate } \\
\text { Tax wedge }\end{array}$ & 1 & & & & \\
Collective bargaining & 0.39 & 1 & & & \\
coverage & 0.47 & 0.61 & 1 & 1 & 1 \\
EPL & 0.16 & 0.67 & 0.55 & 0.44 & 1 \\
PMR (time-varying) & 0.12 & 0.28 & 0.38 & 0.65 & 0.16 \\
High corporatism & 0.30 & -0.04 & 0.25 & 0.65 & 1 \\
\hline
\end{tabular}

As a result, estimates of equation [3] including the entire set of time-invariant policies and institutions suffer from multicollinearity problems. The table below illustrates this issue. In column 1, equation [3] is estimated using the same set of institutions as in the baseline regression of the first section of the main text except that union density is replaced by collective bargaining coverage. The results are in line with those of Blanchard-Wolfers (2000), i.e. all the coefficients have the expected signs and are statistically significant - albeit only at the $10 \%$ level in the case of PMR, with the exception of the tax wedge which is negatively signed. While most of the policy indicators keep the same sign and the same level of statistical significance when studied in separate equations (columns 2-7), the coefficient of the tax wedge becomes positive and significant (column 3). One cannot draw robust policy conclusions from these equations either, as the positive coefficient of the tax wedge could simply capture the positive impact of another policy variable to which the tax wedge is strongly correlated.

There is no straightforward way to address the multicollinearity issue. Here, in order to identify the relevant policy variables with a higher degree of confidence, the following strategy is implemented. Equation [3] is first estimated with two variables for all (the 15) possible pairs of policies and institutions. Those policies and/or institutions that are found to be insignificant in at least one of the 


\begin{tabular}{|c|c|c|c|c|c|c|c|}
\hline $\begin{array}{r}\text { Box 2. Cross-cou } \\
\text { evidence and co } \\
\text { Interactions be } \\
\text { wi }\end{array}$ & $\begin{array}{l}\text { intry corr } \\
\text { onsequen } \\
\text { etween ins } \\
\text { ith unobse }\end{array}$ & $\begin{array}{l}\text { elation } \\
\text { ces for } \\
\text { titutions } \\
\text { rved sho }\end{array}$ & $\begin{array}{l}\text { of poli } \\
\text { econon } \\
\text { and sho } \\
\text { cks, } 197\end{array}$ & $\begin{array}{l}\text { cies and } \\
\text { metric al } \\
\text { cks: vario } \\
0-2003\end{array}$ & $\begin{array}{l}\text { institu } \\
\text { nalysis } \\
\text { us mode }\end{array}$ & $\begin{array}{l}\text { tions: } \\
\text { (cont.) } \\
\text { els }\end{array}$ & \\
\hline Interactions shocks/institutions & 1 & 2 & 3 & 4 & 5 & 6 & 7 \\
\hline Replacement rate & $\begin{array}{l}0.03 \\
{[7.68]^{* * *}}\end{array}$ & $\begin{array}{c}0.03 \\
{[6.80]^{* * *}}\end{array}$ & & & & & \\
\hline Tax wedge & $\begin{array}{l}-0.03 \\
{[4.05]^{* * *}}\end{array}$ & & $\begin{array}{c}0.02 \\
{[3.17]^{* * *}}\end{array}$ & & & & \\
\hline Collective 1 bargaining coverage & $\begin{array}{l}0.01 \\
{[3.90]^{* * *}}\end{array}$ & & & $\begin{array}{l}0.01 \\
{[5.16]^{* * *}}\end{array}$ & & & \\
\hline EPL & $\begin{array}{c}0.11 \\
{[2.28]^{* *}}\end{array}$ & & & & $\begin{array}{c}0.11 \\
{[2.92]^{* * *}}\end{array}$ & & \\
\hline PMR & $\begin{array}{c}0.06 \\
{[1.73]^{*}}\end{array}$ & & & & & $\begin{array}{l}0.17 \\
{[5.59]^{* * *}}\end{array}$ & \\
\hline High corporatism & $\begin{array}{l}-0.98 \\
{[10.21]^{* * *}}\end{array}$ & & & & & & $\begin{array}{l}-0.54 \\
{[5.54]^{* * *}}\end{array}$ \\
\hline Observations & 669 & 669 & 669 & 669 & 669 & 669 & 669 \\
\hline R-squared & 0.81 & 0.77 & 0.76 & 0.77 & 0.76 & 0.77 & 0.77 \\
\hline
\end{tabular}

estimate equations with three variables. The selection procedure continues until a final model is selected. It can be safely inferred from this "statistical tournament" that "surviving" policies and/or institutions significantly affect unemployment via their interaction with shocks. The final model selected through this procedure contains two variables (Table 7, column 1): consistent with previous results, high unemployment benefits are found to amplify the unemployment effects of a given shock, while a high degree of corporatism has the opposite effect. ${ }^{60}$ Taken at face value, the estimates suggest that a 10 percentage points increase in the average benefit replacement rate raises the impact of a 1 percentage point ex ante unemployment shock by 0.4 percentage point ex post, while switching to a highly centralised/co-ordinated bargaining system would reduce it by 0.8 percentage point. No firm conclusions can be drawn as regards discarded policies and/or institutions - given that any possible significant impact may have been obscured by the even more significant effect of other variables, even though their impact seems to fit with theoretical priors. 
Table 7. Interactions between institutions and shocks:

final models with unobserved shocks, 1970-2003

\begin{tabular}{|c|c|c|c|c|}
\hline & 1 & 2 & 3 & 4 \\
\hline & $\begin{array}{c}\text { Final model } \\
\text { selected } \\
1970-2003\end{array}$ & $\begin{array}{c}=1 \\
\text { with control } \\
\text { for direct effect } \\
\text { of institutions } \\
\text { 1975-2003 }\end{array}$ & $\begin{array}{c}=1 \\
\text { with ALMPs and } \\
\text { control for direct } \\
\text { effect of institutions, } \\
1975-2003\end{array}$ & $\begin{array}{l}\quad=1 \\
\text { with home ownership } \\
\text { and control for direct } \\
\text { effect of institutions, } \\
1975-2003\end{array}$ \\
\hline \multicolumn{5}{|l|}{ Direct effect of institutions: } \\
\hline \multirow[t]{2}{*}{ Average replacement rate } & & 0.06 & 0.07 & 0.07 \\
\hline & & {$[3.73]^{* * *}$} & {$[4.41]^{* * *}$} & {$[4.51]^{* * *}$} \\
\hline \multirow[t]{2}{*}{ Tax wedge } & & 0.18 & 0.17 & 0.19 \\
\hline & & {$[5.08]^{* * *}$} & {$[4.85]^{* * *}$} & {$[5.14]^{* * *}$} \\
\hline \multirow[t]{2}{*}{ Union density } & & -0.03 & -0.01 & -0.01 \\
\hline & & [1.38] & {$[0.65]$} & {$[0.65]$} \\
\hline \multirow[t]{2}{*}{ PMR } & & 0.34 & 0.41 & 0.15 \\
\hline & & {$[1.73]^{*}$} & {$[2.15]^{* *}$} & {$[0.77]$} \\
\hline \multirow[t]{2}{*}{ High corporatism } & & -1.38 & -1.75 & -1.79 \\
\hline & & {$[4.40]^{* * *}$} & {$[5.37]^{* * *}$} & {$[5.26]^{* * *}$} \\
\hline \multicolumn{5}{|c|}{ Interactions shocks/institutions: } \\
\hline \multirow[t]{2}{*}{ Average replacement rate } & 0.04 & 0.04 & 0.05 & 0.04 \\
\hline & {$[9.50]^{* * *}$} & {$[6.21]^{* * *}$} & {$[6.64]^{* * *}$} & {$[6.44]^{* * *}$} \\
\hline \multirow[t]{2}{*}{ High corporatism } & -0.85 & -0.95 & -0.89 & -0.65 \\
\hline & {$[8.65]^{* * *}$} & {$[5.43]^{* * *}$} & {$[5.16]^{* * *}$} & {$[3.88]^{* * *}$} \\
\hline \multirow[t]{2}{*}{ ALMPs } & & & -0.01 & \\
\hline & & & {$[3.58]^{* * *}$} & \\
\hline \multirow[t]{2}{*}{ Home ownership } & & & & 0.03 \\
\hline & & & & {$[4.92]^{* * *}$} \\
\hline Country dummies & Yes & Yes & Yes & Yes \\
\hline Time dummies & Yes & Yes & Yes & Yes \\
\hline Observations & 669 & 516 & 516 & 468 \\
\hline R-squared & 0.80 & 0.87 & 0.87 & 0.88 \\
\hline
\end{tabular}

Non-linear least squares. Absolute value of $\mathrm{t}$ statistics in brackets.

$*^{*},{ }^{* *},{ }^{* * *}$ statistically significant at the $10 \%, 5 \%$ and $1 \%$ levels, respectively.

Source: Authors' estimates on the basis of data sources described in Annex 2. 
Column 2 of Table 7 augments equation [3] with the direct effect of policies and institutions on unemployment, which comes over and above their impact via interactions with shocks:

$$
U_{i t}=\sum_{j} \beta_{j} X_{i t}^{j}+\lambda_{t}\left(1+\sum_{j} \gamma_{j}\left(\bar{X}_{i}^{j}-\bar{X}^{j}\right)\right)+\alpha_{i}+\varepsilon_{i t}
$$

where $\sum \beta_{j} X_{i t}^{j}$ is the usual set of time-varying policies and institutions. In order to expand $^{j}$ as much as possible the sample period, EPL is omitted, which should come at a minimal cost given the lack of significance of this policy indicator in the baseline unemployment regression of Section 1. Also, the tax wedge considered here is not derived from OECD tax models but rather comes from National Accounts. ${ }^{61}$ As a result of these changes, equation [4] can be estimated over the period 1975-2003.

Two main results stand out. First, the impact of interactions between shocks and policies and/or institutions is found to be robust to controls for the direct effects of institutions, as illustrated by the statistically significant coefficients of unemployment benefits and the high corporatism dummy variable in $\bar{X}_{i}^{j}$. Second, the direct effects of policies and institutions appear to be consistent with those estimated in Section 1, i.e. unemployment benefits, the tax wedge and PMR albeit only at the $10 \%$ level - tend to increase unemployment, while a high degree of corporatism tends to reduce it. Overall, these findings can be interpreted as evidence that direct and indirect effects of policies and institutions complement each other in explaining unemployment trends. There is also tentative evidence that expenditures on ALMPs lessen the unemployment effects of shocks (Table 7, column 3) while high rates of home ownership amplify them (column 4), even though - as is the case for most other explanatory variables - not too much should be made of these findings due to potential multicollinearity problems.

\section{Observed shocks}

In order get a better grasp of the nature of shocks affecting unemployment, the set of time dummies used previously can be replaced by the set of observable shocks considered in Section 1:

$$
U_{i t}=\sum_{j} \beta_{j} X_{i t}^{j}+\left(\sum_{l} \varphi_{l} Z_{i t}^{l}\right)\left(1+\sum_{j} \gamma_{j}\left(\bar{X}_{i}^{j}-\bar{X}^{j}\right)\right)+\alpha_{i}+\varepsilon_{i t}
$$

where $\sum \varphi_{l} Z_{i t}^{l}$ is the set of observed macroeconomic variables - labelled here "shocks" - to be interacted with policies and institutions. ${ }^{62}$

Table 8 indicates that these shocks indeed affect unemployment not only directly but also indirectly via their interactions with certain policies and institutions. The conclusions drawn previously from equations with unobserved shocks are largely 
Table 8. Interactions between shocks and institutions: models with observed shocks

\begin{tabular}{|c|c|c|c|}
\hline & 1 & 2 & 3 \\
\hline & $\begin{array}{l}\text { Final model selected } \\
\text { with interactions }\end{array}$ & $\begin{array}{l}=1 \\
\text { with control for direct effect } \\
\text { of institutions }\end{array}$ & $\begin{array}{l}\quad=2 \\
\text { with labour demand shock }\end{array}$ \\
\hline & $1975-2003$ & $1975-2003$ & $1975-2003$ \\
\hline \multicolumn{4}{|l|}{ Direct effect of institutions: } \\
\hline \multirow[t]{2}{*}{ Average replacement rate } & & 0.06 & 0.04 \\
\hline & & {$[3.54]^{* * *}$} & {$[2.46]^{* *}$} \\
\hline \multirow[t]{2}{*}{ Tax wedge } & & 0.21 & 0.22 \\
\hline & & {$[6.08]^{* * *}$} & {$[6.30]^{* * *}$} \\
\hline \multirow[t]{2}{*}{ Union density } & & -0.01 & -0.02 \\
\hline & & {$[0.37]$} & {$[0.88]$} \\
\hline \multirow[t]{2}{*}{ PMR } & & 0.29 & 0.33 \\
\hline & & {$[1.96]^{*}$} & {$[2.30]^{* *}$} \\
\hline \multirow[t]{2}{*}{ High corporatism } & & -0.96 & -1.02 \\
\hline & & {$[2.97]^{* * *}$} & {$[3.35]^{* * *}$} \\
\hline \multicolumn{4}{|c|}{ Interactions shocks/institutions: } \\
\hline \multirow[t]{2}{*}{ Average replacement rate } & 0.05 & 0.04 & 0.06 \\
\hline & {$[5.90]^{* * *}$} & {$[4.65]^{* * *}$} & {$[6.44]^{* * *}$} \\
\hline \multirow[t]{2}{*}{ High corporatism } & -0.89 & -0.80 & -1.30 \\
\hline & {$[4.83]^{* * *}$} & {$[3.91]^{* * *}$} & {$[5.41]^{* * *}$} \\
\hline \multicolumn{4}{|l|}{ Direct effect of shocks: } \\
\hline \multirow[t]{2}{*}{ TFP shock } & -10.81 & -12.65 & -5.92 \\
\hline & {$[3.35]^{* * *}$} & {$[3.99]^{* * *}$} & {$[2.18]^{* *}$} \\
\hline \multirow[t]{2}{*}{ Terms of trade shock } & 4.95 & 5.97 & 7.09 \\
\hline & {$[3.94]^{* * *}$} & {$[3.26]^{* * *}$} & {$[4.46]^{* * *}$} \\
\hline \multirow[t]{2}{*}{ Interest rate shock } & 0.42 & 0.34 & 0.29 \\
\hline & {$[15.36]^{* * *}$} & {$[11.87]^{* * *}$} & {$[10.77]^{* * *}$} \\
\hline \multirow[t]{2}{*}{ Labour demand shock } & & & 11.45 \\
\hline & & & {$[4.36]^{* * *}$} \\
\hline Country dummies & Yes & Yes & Yes \\
\hline Time dummies & Yes & Yes & Yes \\
\hline Observations & 548 & 505 & 487 \\
\hline R-squared & 0.79 & 0.86 & 0.88 \\
\hline
\end{tabular}

Non-linear least squares. Absolute value of $\mathrm{t}$ statistics in brackets.

$*,{ }^{* *},{ }^{* *}$ statistically significant at the $10 \%, 5 \%$ and $1 \%$ levels, respectively.

Source: Authors' estimates on the basis of data sources described in Annex 2.

confirmed when observed shocks are used instead. Overall, these and previous estimates strongly suggest that policies and institutions, macroeconomic shocks and 40 interactions between them all contribute to shape unemployment patterns. 


\section{Disentangling amplification from persistence effects}

By construction, the static framework used up to here (Tables 7 and 8) provides no clue as to whether policies and institutions amplify (mitigate) the initial unemployment effect of a shock and/or make it more (less) persistent. Both of these aspects contribute to determine the degree of resilience of labour markets to adverse macroeconomic shocks. In this respect, those policies and institutions that amplify the initial impact of a shock may not necessarily increase its persistence, and vice versa. For instance, high firing costs may deter firms from laying off workers in the short run, but they might slow down the wage adjustment process as well as workers' reallocation towards more productive jobs, thereby delaying the return of unemployment to its lower initial level. Likewise, stringent PMR creates rents that allow firms to minimise lay-offs in the short run, but it may slow down resource reallocation and lengthen the period of excess unemployment by making labour demand less responsive to the likely decline in wages. To explore this issue further, various versions of the following dynamic model with unobserved shocks are estimated:

$$
\Delta U_{i t}=-\left(\phi-\sum_{j} \gamma_{j}\left(\bar{X}_{i}^{j}-\bar{X}^{j}\right)\right) U_{i t-1}+\lambda_{t}\left(1+\sum_{k} \gamma_{k}\left(\bar{X}_{i}^{k}-\bar{X}^{k}\right)\right)+\alpha_{i}+\varepsilon_{i t}
$$

This equation clearly disentangles amplification from persistence mechanisms. The lagged unemployment term on the right-hand side captures unemployment persistence, while the second one describes short-term interactions between institutions and shocks, i.e. the amplification mechanism. Both the persistence and amplification of unobserved shocks are supposed to be a function of policies and institutions. A positive (negative) and significant $\gamma_{i}$ implies that the policy or institution $\bar{X}_{i}^{j}$ considered increases (reduces) the persistence of unemployment. Likewise, a positive (negative) and significant $\gamma_{k}$ implies that the policy or institution $\bar{X}_{i}^{k}$ considered amplifies (mitigates) the initial unemployment effect of a shock.

The starting point of the analysis is the final, static model selected previously, either with unobserved or observed shocks (Table 7, column 2, and Table 8, column 3, respectively). Dynamic versions of this model ${ }^{63}$ suggest that unemployment benefits and a high degree of corporatism affect the initial impact of a shock but not adjustment mechanisms (Tables 9 and 10, column 1) ${ }^{64}$ Consequently, both of these institutions are dropped from the lagged unemployment coefficient (Tables 9 and 10, column 2), and the equation obtained serves as a basis for the reassessment of those policies and institutions which were not found to be robust to the selection procedure followed earlier. Each of these is studied in separate regressions in order to keep parsimonious specifications and minimise multicollinearity problems.

There is evidence that a high tax wedge mitigates the initial impact of a shock, possibly reflecting the stronger role played by fiscal stabilisers in high-tax countries, 
Table 9. Disentangling persistence from amplification effects: unobserved shocks, 1970-2003

\begin{tabular}{|c|c|c|c|c|c|c|c|c|}
\hline & 1 & 2 & 3 & 4 & 5 & 6 & 7 & 8 \\
\hline & $\begin{array}{l}\text { Final model } \\
\text { selected } \\
\text { in the static } \\
\text { regressions }\end{array}$ & $\begin{array}{c}=1 \\
\text { with } \\
\text { significant } \\
\text { terms only }\end{array}$ & $\begin{array}{l}\quad=2 \\
\text { with tax } \\
\text { wedge }\end{array}$ & $\begin{array}{c}=2 \\
\text { with } \\
\text { union } \\
\text { coverage }\end{array}$ & $\begin{array}{l}=2 \\
\text { with } \\
\text { EPL }\end{array}$ & $\begin{array}{l}=2 \\
\text { with } \\
\text { PMR }\end{array}$ & $\begin{array}{c}=2 \\
\text { with } \\
\text { ALMPs }\end{array}$ & $\begin{array}{c}\quad=2 \\
\text { with home } \\
\text { ownership }\end{array}$ \\
\hline \multicolumn{9}{|l|}{ Persistence coefficient: } \\
\hline & {$[4.89]^{* * *}$} & {$[4.98]^{* * *}$} & {$[5.02]^{* * *}$} & {$[4.60]^{* * *}$} & {$[5.39]^{* * *}$} & {$[5.69]^{* * *}$} & {$[5.37]^{* * *}$} & {$[5.33]^{* * *}$} \\
\hline \multicolumn{9}{|l|}{$\begin{array}{l}\text { Effect of institutions on } \\
\text { persistence of shocks: } \gamma_{j}\end{array}$} \\
\hline Average replacement rate & $\begin{array}{r}-0.012 \\
{[0.79]}\end{array}$ & & & & & & & \\
\hline Tax wedge & & & $\begin{array}{l}0.009 \\
{[0.52]}\end{array}$ & & & & & \\
\hline \multicolumn{2}{|c|}{ Collective bargaining coverage } & & & $\begin{array}{l}0.018 \\
{[1.71]^{*}}\end{array}$ & & & & \\
\hline EPL & & & & & $\begin{array}{l}0.190 \\
{[1.90]^{*}}\end{array}$ & & & \\
\hline PMR & & & & & & $\begin{array}{l}0.697 \\
{[4.55]^{* * *}}\end{array}$ & & \\
\hline High corporatism & $\begin{array}{r}-0.354 \\
{[1.17]}\end{array}$ & & & & & & & \\
\hline ALMPs & & & & & & & $\begin{array}{l}-0.015 \\
{[2.21]^{* *}}\end{array}$ & \\
\hline Home ownership & & & & & & & & $\begin{array}{l}0.020 \\
{[2.61]^{* * *}}\end{array}$ \\
\hline \multicolumn{9}{|c|}{$\begin{array}{l}\text { Effect of institutions on amplification } \\
\text { of shocks: }\end{array}$} \\
\hline \multirow[t]{2}{*}{ Average replacement rate } & 0.035 & 0.034 & 0.039 & 0.031 & 0.035 & 0.032 & 0.036 & 0.041 \\
\hline & {$[5.59]^{* * *}$} & {$[5.45]^{* * *}$} & {$[5.61]^{* * *}$} & {$[4.48]^{* * *}$} & {$[5.63]^{* * *}$} & {$[5.50]^{* * *}$} & {$[5.78]^{* * *}$} & {$[5.64]^{* * *}$} \\
\hline \multirow[t]{2}{*}{ Tax wedge } & & & -0.015 & & & & & \\
\hline & & & {$[1.93]^{*}$} & & & & & \\
\hline \multicolumn{2}{|c|}{ Collective bargaining coverage } & & & 0.003 & & & & \\
\hline & & & & {$[0.90]$} & & & & \\
\hline \multirow[t]{2}{*}{ EPL } & & & & & -0.137 & & & \\
\hline & & & & & {$[2.46]^{* *}$} & & & \\
\hline \multirow[t]{2}{*}{ PMR } & & & & & & -0.057 & & \\
\hline & & & & & & [0.78] & & \\
\hline \multirow[t]{2}{*}{ High corporatism } & -0.729 & -0.725 & -0.768 & -0.778 & -0.717 & -0.519 & -0.688 & -0.624 \\
\hline & {$[4.66]^{* * *}$} & {$[4.65]^{* * *}$} & {$[4.82]^{* * *}$} & {$[5.06]^{* * *}$} & {$[4.66]^{* * *}$} & {$[3.57]^{* * *}$} & {$[4.37]^{* * *}$} & * $[3.49]^{* * *}$ \\
\hline ALMPs & & & & & & & $\begin{array}{r}-0.003 \\
{[1.19]}\end{array}$ & \\
\hline \multirow[t]{2}{*}{ Home ownership } & & & & & & & & 0.024 \\
\hline & & & & & & & & {$[3.61]^{* * *}$} \\
\hline
\end{tabular}


Table 9. Disentangling persistence from amplification effects: unobserved shocks, 1970-2003 (cont.)

\begin{tabular}{|c|c|c|c|c|c|c|c|c|}
\hline & 1 & 2 & 3 & 4 & 5 & 6 & 7 & 8 \\
\hline & $\begin{array}{l}\text { Final model } \\
\text { selected } \\
\text { in the static } \\
\text { regressions }\end{array}$ & $\begin{array}{c}=1 \\
\text { with } \\
\text { significant } \\
\text { terms only }\end{array}$ & $\begin{array}{l}\quad=2 \\
\text { with tax } \\
\text { wedge }\end{array}$ & $\begin{array}{c}=2 \\
\text { with } \\
\text { union } \\
\text { coverage }\end{array}$ & $\begin{array}{l}=2 \\
\text { with } \\
\text { EPL }\end{array}$ & $\begin{array}{l}=2 \\
\text { with } \\
\text { PMR }\end{array}$ & $\begin{array}{c}=2 \\
\text { with } \\
\text { ALMPs }\end{array}$ & $\begin{array}{c}\quad=2 \\
\text { with home } \\
\text { ownership }\end{array}$ \\
\hline Country dummies & Yes & Yes & Yes & Yes & Yes & Yes & Yes & Yes \\
\hline Time dummies & Yes & Yes & Yes & Yes & Yes & Yes & Yes & Yes \\
\hline Observations & 646 & 646 & 646 & 646 & 646 & 646 & 646 & 586 \\
\hline R-squared & 0.42 & 0.41 & 0.42 & 0.42 & 0.42 & 0.45 & 0.42 & 0.44 \\
\hline
\end{tabular}

Non-linear least squares. Absolute value of $\mathrm{t}$ statistics in brackets.

$*, * *, * * *$ statistically significant at the $10 \%, 5 \%$ and $1 \%$ levels, respectively.

Source: Authors' estimates on the basis of data sources described in Annex 2.

while no significant effect is found on persistence (Tables 9 and 10, column 3). The strength of unions in wage bargaining - as captured by collective bargaining coverage - seems to increase persistence, although its impact is significant only at the $10 \%$ level and when unobserved shocks are considered (Table 9, column 4). As expected, stringent EPL and PMR appear to reduce the short-run impact of an adverse shock but lengthen the adjustment process, although the negative short-run effect of PMR is significant only when observed shocks are considered (Tables 9 and 10, column 5). This finding suggests that EPL and PMR were eliminated by the selection procedure of the static model because they have opposite effects on amplification and persistence.$^{65}$ High expenditures on ALMPs are found to reduce the persistence of shocks, and possibly their initial impact (Tables 9 and 10, column 7), providing some support for the view that certain categories of ALMPs improve the job-matching process. Finally, high rates of home ownership seem to amplify the initial impact of shocks while also lengthening the adjustment process, although the persistence effect is insignificant when observed shocks are considered (Tables 9 and 10, column 8).

The main conclusion of this Section is that policies and institutions not only affect unemployment patterns via their direct effects but also via their interactions with economic shocks. There is clear empirical evidence that the unemployment effects of TFP, terms of trade, real interest rate and labour demand shocks are at least partly shaped by the policy and institutional framework. Identifying precisely which policies and institutions matter in this respect is not straightforward, not least because most countries tend to have similar policy stances - either lax or stringent - in all areas. Still, the econometric analysis points to a number of policy conclusions. In particular, high unemployment benefits are found to amplify the 
Table 10. Disentangling persistence from amplification effects: observed shocks, 1970-2003

\begin{tabular}{|c|c|c|c|c|c|c|c|c|}
\hline & 1 & 2 & 3 & 4 & 5 & 6 & 7 & 8 \\
\hline & $\begin{array}{l}\text { Final model } \\
\text { selected } \\
\text { in the static } \\
\text { regressions }\end{array}$ & $\begin{array}{c}=1 \\
\text { with } \\
\text { significant } \\
\text { terms only }\end{array}$ & $\begin{array}{c}=2 \\
\text { with } \\
\text { tax } \\
\text { wedge }\end{array}$ & $\begin{array}{c}=2 \\
\text { with } \\
\text { union } \\
\text { coverage }\end{array}$ & $\begin{array}{l}=2 \\
\text { with } \\
\text { EPL }\end{array}$ & $\begin{array}{c}=2 \\
\text { with } \\
\text { PMR }\end{array}$ & $\begin{array}{c}=2 \\
\text { with } \\
\text { ALMPs }\end{array}$ & $\begin{array}{c}=2 \\
\text { with } \\
\text { home } \\
\text { ownership }\end{array}$ \\
\hline $\begin{array}{l}\text { Persistence coefficient: } \\
\qquad 1-\phi\end{array}$ & 0.901 & 0.901 & 0.895 & 0.901 & 0.888 & 0.889 & 0.893 & 0.892 \\
\hline $\begin{array}{l}\text { Effect of institutions on } \\
\text { persistence of shocks: } \gamma_{j}\end{array}$ & {$[5.88]^{* * *}$} & {$[6.76]^{* * *}$} & {$[6.80]^{* * *}$} & {$[6.72]^{* * *}$} & {$[7.24]^{* * *}$} & {$[7.56]^{* * *}$} & {$[7.18]^{* * *}$} & {$[6.42]^{* * *}$} \\
\hline Average replacement rate & $\begin{array}{r}-0.015 \\
{[1.00]}\end{array}$ & & & & & & & \\
\hline Tax wedge & & & $\begin{array}{l}0.013 \\
{[0.85]}\end{array}$ & & & & & \\
\hline Collective bargaining cove & rage & & & $\begin{array}{l}0.005 \\
{[0.58]}\end{array}$ & & & & \\
\hline EPL & & & & & $\begin{array}{l}0.168 \\
{[1.87]^{*}}\end{array}$ & & & \\
\hline PMR & & & & & & $\begin{array}{l}0.248 \\
{[3.65]^{* * *}}\end{array}$ & & \\
\hline High corporatism & $\begin{array}{c}-0.479 \\
{[1.74]^{*}}\end{array}$ & & & & & & & \\
\hline ALMPs & & & & & & & $\begin{array}{l}-0.014 \\
{[2.15]^{* *}}\end{array}$ & \\
\hline Home ownership & & & & & & & & $\begin{array}{l}0.010 \\
{[1.16]}\end{array}$ \\
\hline $\begin{array}{l}\text { Effect of institutions on am } \\
\text { of shocks: }\end{array}$ & iplification & & & & & & & \\
\hline Average replacement rate & $\begin{array}{l}0.020 \\
{[3.14]^{* * *}}\end{array}$ & $\begin{array}{l}0.019 \\
{[2.96]^{* * *}}\end{array}$ & $\begin{array}{l}0.028 \\
{[3.82]^{* * *}}\end{array}$ & $\begin{array}{l}0.021 \\
{[2.85]^{* * *}}\end{array}$ & $\begin{array}{l}0.021 \\
{[3.31]^{* * *}}\end{array}$ & $\begin{array}{l}0.015 \\
{[2.20]^{* *}}\end{array}$ & $\begin{array}{l}0.021 \\
{[3.42]^{* * *}}\end{array}$ & $\begin{array}{l}0.026 \\
{[3.27]^{* * *}}\end{array}$ \\
\hline Tax wedge & & & $\begin{array}{l}-0.026 \\
{[2.80]^{* * *}}\end{array}$ & & & & & \\
\hline Collective bargaining cove & rage & & & $\begin{array}{r}-0.002 \\
{[0.64]}\end{array}$ & & & & \\
\hline EPL & & & & & $\begin{array}{l}-0.218 \\
{[3.78]^{* * *}}\end{array}$ & & & \\
\hline PMR & & & & & & $\begin{array}{l}-0.191 \\
{[3.22]^{* * *}}\end{array}$ & & \\
\hline High corporatism & $\begin{array}{r}-0.592 \\
{[3.44]^{* * *}}\end{array}$ & $\begin{array}{l}-0.596 \\
{[3.41]^{* * *}}\end{array}$ & $\begin{array}{l}-0.703 \\
{[3.91]^{* * *}}\end{array}$ & $\begin{array}{l}-0.607 \\
{[3.38]^{* * *}}\end{array}$ & $\begin{aligned}-0.660 \\
\\
{[3.86]^{* * *} }\end{aligned}$ & $\begin{aligned}-0.531 \\
\\
{[2.95]^{* * *} }\end{aligned}$ & $\begin{array}{l}-0.525 \\
{[3.07]^{* * *}}\end{array}$ & $\begin{array}{l}-0.658 \\
{[3.21]^{* * *}}\end{array}$ \\
\hline ALMPS & & & & & & & $\begin{array}{l}-0.005 \\
{[2.29]^{* *}}\end{array}$ & \\
\hline Home ownership & & & & & & & & $\begin{array}{l}0.016 \\
{[2.28]^{* *}}\end{array}$ \\
\hline
\end{tabular}


Table 10. Disentangling persistence from amplification effects: observed shocks, 1970-2003 (cont.)

\begin{tabular}{|c|c|c|c|c|c|c|c|c|}
\hline & 1 & 2 & 3 & 4 & 5 & 6 & 7 & 8 \\
\hline & $\begin{array}{c}\text { Final model } \\
\text { selected } \\
\text { in the static } \\
\text { regressions }\end{array}$ & $\begin{array}{c}=1 \\
\text { with } \\
\text { significant } \\
\text { terms only }\end{array}$ & $\begin{array}{c}=2 \\
\text { with } \\
\text { tax } \\
\text { wedge }\end{array}$ & $\begin{array}{c}=2 \\
\text { with } \\
\text { union } \\
\text { coverage }\end{array}$ & $\begin{array}{l}=2 \\
\text { with } \\
\text { EPL }\end{array}$ & $\begin{array}{c}=2 \\
\text { with } \\
\text { PMR }\end{array}$ & $\begin{array}{c}=2 \\
\text { with } \\
\text { ALMPs }\end{array}$ & $\begin{array}{c}=2 \\
\text { with } \\
\text { home } \\
\text { ownership }\end{array}$ \\
\hline Country dummies & Yes & Yes & Yes & Yes & Yes & Yes & Yes & Yes \\
\hline Time dummies & Yes & Yes & Yes & Yes & Yes & Yes & Yes & Yes \\
\hline Observations & 604 & 604 & 604 & 604 & 604 & 604 & 604 & 548 \\
\hline R-squared & 0.38 & 0.37 & 0.38 & 0.37 & 0.39 & 0.39 & 0.38 & 0.38 \\
\hline
\end{tabular}

Non-linear least squares. Absolute value of $\mathrm{t}$ statistics in brackets.

$*, * *,{ }^{* *}$ statistically significant at the $10 \%, 5 \%$ and $1 \%$ levels, respectively.

Source: Authors' estimates on the basis of data sources described in Annex 2.

unemployment effects of adverse shocks. By contrast, a high degree of corporatism appears to improve the resilience of the labour market. There is more tentative evidence that high expenditures on ALMPs have similar effects, while by contrast high rates of home ownership appear to slow down labour market adjustment. Also, stringent EPL and/or PMR, while mitigating the initial impact of adverse shocks, seem to make it more persistent.

\section{CONCLUSIONS}

This paper contributes to existing macroeconometric literature on the institutional and policy determinants of unemployment on two main grounds: i) using up-to-date OECD data on policies and institutions, it presents a new set of estimates, putting particular emphasis on robustness issues which have often received little attention in previous studies; and, ii) it addresses issues that have emerged more recently in the literature, such as the impact of product market regulation, interactions among policies and institutions, and the effect of policies and institutions on economic resilience to macroeconomic shocks.

The main findings of the paper can be summarised as follows:

- On average, changes in policies and institutions appear to explain almost two thirds of non-cyclical unemployment changes over the past two decades. In particular, high and long-lasting unemployment benefits, high tax wedges and stringent anti-competitive product market regulation (PMR) are found to increase aggregate unemployment. On average, it is estimated that a 10 percentage point reduction in the tax wedge, a 10 percentage point reduction of unemployment benefits and/or a decline in product market 
regulation by two standard deviations would be associated with a drop in the unemployment rate by about $2.8,1.2$ and 0.7 percentage points, respectively. By contrast, and in line with a number of previous studies, no significant impact of employment protection legislation (EPL) on aggregate unemployment is found. Extensive sensitivity analysis shows that these findings are robust across specifications, datasets and econometric methods. More tentatively, highly centralised and/or co-ordinated wage bargaining systems as well as some categories of public spending on active labour market programmes (ALMPs), such as labour market training, are estimated to be associated with lower unemployment.

- A few specific policy interactions seem to be particularly robust: in particular, the impact of generous unemployment benefits on unemployment appears to be mitigated by high public spending on ALMPs, perhaps because high spending on ALMPs is often accompanied with strong emphasis on "activation". Also, the unemployment effects of high tax wedges are found to be largest in those countries where binding minimum wage floors prevent tax shifting to workers.

- Finally, while policies and institutions appear to play a major role in shaping unemployment patterns, macroeconomic conditions also matter. Negative total factor productivity shocks, deteriorations in the terms of trade, increases in long-term real interest rates or negative labour demand shocks are all found to increase aggregate unemployment. Furthermore, there is clear evidence that their impact is shaped by existing policies and institutions. In particular, the effects of macroeconomic shocks appear to be amplified by high unemployment benefits and dampened by highly centralised and/or co-ordinated wage bargaining systems. More tentatively, high rates of home ownership - which are often associated with low degrees of labour mobility across regions - increase the unemployment impact of shocks, while public spending on ALMPs reduces it. By contrast, the effects of strict EPL or stringent PMR appear to be ambiguous. They seem to dampen the unemployment effects of shocks in the short run, while lengthening the adjustment period needed for unemployment to return to its initial level. 


\section{NOTES}

1. One exception in this respect is Scarpetta (1996).

2. See Annex 1 for some theoretical discussion, and Annex 2 for details on the construction of corresponding indicators.

3. Australia, Austria, Belgium, Canada, Denmark, Finland, France, Germany, Ireland, Italy, Japan, Netherlands, Norway, New Zealand, Portugal, Spain, Sweden, Switzerland, United Kingdom, United States.

4. Following standard practice for repeated cross-section data, time effects are always included in the regressions of this paper in order to control for shocks that are common across countries. Except in part of the sensitivity analysis, country effects are also always included and modelled through deterministic dummy variables. The inclusion of country effects is necessary to control for country-specific averages of omitted policies and institutions. Since the policy and institutional indicators included in the analysis tend to be much more correlated across countries than within a given country and over time (see below), one can expect that the inclusion of country effects is sufficient to control for most of the relevant omitted variables. The choice of fixed rather than random country effects reflects the view that country effects are unlikely to be independent from other explanatory variables included in the estimated equation - in which case random-effects FGLS estimators would yield inconsistent estimates.

5. This PMR indicator is used here because it is available over the whole period 1975-2003 for most OECD countries, unlike the economy-wide indicator which covers only the period 1998-2003. One drawback is that changes in the PMR indicator for nonmanufacturing industries do not incorporate all aspects of regulatory reforms that have been undertaken by a number of OECD countries in the past decades, such as administrative reforms affecting all sectors. As a result, the unemployment effects of regulatory reforms may not be fully captured by the econometric estimates presented in this paper.

6. Also, in job-search models of the labour market, if technological progress is not embodied in new jobs - i.e. if it can materialise without existing jobs being destroyed and replaced by new ones, faster productivity growth increases the value of jobs through "capitalisation effects" (Pissarides, 2000). The latter reflect the fact that firms pay the cost of job creation upfront and recover it later from the revenues generated over the lifetime of the job. These "capitalisation effects" increase labour demand and reduce unemployment. Conversely, if technological progress is embodied in new jobs, faster productivity growth may lead to more "creative destruction", i.e. higher turnover and higher unemployment (Aghion and Howitt, 1994). Within this context, existing empirical literature on the negative relationship between productivity growth and unemployment may be interpreted as evidence of predominantly disembodied technological progress (Pissarides and Vallanti, 2005). 
7. The logic behind the use of this variable as a proxy for labour demand shocks is the following. If the aggregate production function characterising the economy is Cobb-Douglas $\left(\mathrm{Y}=\mathrm{A} \mathrm{L}{ }^{\alpha} \mathrm{K}^{1-\alpha}\right)$, then in long-run equilibrium $\alpha=\left[\mathrm{Y}^{\prime}(\mathrm{L}) \mathrm{L}\right] /\left[\mathrm{P}_{\mathrm{Y}} \mathrm{Y}\right]$, where $\mathrm{Y}^{\prime}(\mathrm{L})$ is the marginal product of labour, $\mathrm{L}$ is total employment and $\mathrm{P}_{\mathrm{Y}} \mathrm{Y}$ is total nominal value added. If one further assumes that imperfections in goods and/or labour markets drive a wedge between the wage rate and the marginal product of labour, denoted $\mu=w / Y^{\prime}$ (L), then the equilibrium labour share is: $[\mathrm{w} L] /\left[\mathrm{P}_{\mathrm{Y}} \mathrm{Y}\right]=\alpha \mu$. Therefore, the equilibrium labour share may decline as a result of declines in either $\alpha$ or $\mu$. In the short-run, however, the observed labour share may also vary as a result of changes in factor prices that are not immediately and fully offset by corresponding changes in factor proportions - as is the case in the long-run if the production function is Cobb-Douglas. Therefore, the observed labour share is purged here of these short-run effects, following for simplicity and comparability purposes the same methodology as Blanchard (1998). This yields an "adjusted" labour share, which should a priori vary only as a result of changes in either $\alpha$ or $\mu$.

8. The largest downturn observed over the sample period occurred in Finland and Sweden in those years: in no other country/period did unemployment double and change by more than 4 percentage points over a two-year period. While no such structural shift is observable in German data, unification provides a sufficient motivation for special treatment.

9. Shift from high to low corporatism in Australia and New Zealand in the early 1990s, shift from low to high corporatism in Ireland and Italy in the mid-1980s and mid-1990s, respectively.

10. In a standard wage-setting/price-setting model, both the effects of firing costs and union bargaining power depend on the parameterisation of the model. For instance, if an efficient bargaining model or a sufficiently concave utility function for unions is used, the short-term impact on unemployment of an increase in union bargaining power is zero or negative, respectively, while the long-run effects crucially depend on the assumptions on firm entry and exit (see e.g. Blanchard and Giavazzi, 2003).

11. The OECD indicator of EPL comprises two main components, namely EPL on temporary contracts and EPL on permanent contracts. It has been suggested that it is the latter that exerts adverse effects on unemployment (see Annex 1). However, when only EPL on permanent contracts is included in the specification, its estimated coefficient remains insignificant.

12. The result obtained for Spain is consistent with previous analysis by Bentolila and Dolado (1994).

13. The source is the OECD Taxing Wages Database (see Bassanini and Duval, 2006, Annex 2), which defines it as the wedge between the labour cost to the employer and the corresponding net take-home pay of the employee for a single-earner couple with two children earning $100 \%$ of APW earnings. The tax wedge expresses the sum of personal income tax and all social security contributions as a percentage of total labour cost.

14. However, this result must be interpreted with caution due to the endogeneity of the output gap.

15. By construction, the value of the indicator of product market regulation for seven nonmanufacturing industries ranges from 0 to 6 . In 2003, its average value and its standard deviation across the 20 countries included in the sample were equal to 2.1 and 0.55 , 
respectively. For the "average" OECD country, a decline by two standard deviations would be equivalent to bringing product market regulation down to the stance observed in the most liberal OECD country (the United Kingdom).

16. Calculated as the difference between the actual change in unemployment between 1982 and 2003 and the change in unemployment that can be assigned to cyclical factors -i.e. to the change in the output gap - over the same period.

17. All regressions in Table 1 - including the baseline - attempt to correct for individual heteroskedasticity using the Huber/White/sandwich estimator of variance. This conservative approach is systematically adopted even though the null assumption of homoskedasticity is not rejected by a White test at conventional confidence levels. However, when testing instead for the more specific group-wise source of heteroskedasticity, the null assumption is rejected. This suggests, as part of a sensitivity analysis, to estimate Feasible Generalised Least Squares regressions under the assumption of country-wise heteroskedasticity. By contrast, the White test statistic is significant in certain specifications if the logarithm of the unemployment rate is used as dependent variable, as suggested by Nickell (1998). For this reason, linear specifications are preferred to log-linear ones in this paper, although it has been checked that the main qualitative results do not depend on this choice (see also below).

18. The fact that the average impact of policies and institutions is estimated in a consistent manner does not imply that they have the same effect for all countries. Therefore, this finding is not inconsistent with the existence of interactions between policies and institutions. In fact $F$ tests of cross-country parameter homogeneity are always rejected at standard levels. This suggests that all estimates presented in this paper can more safely be seen as providing "average" impacts. Additionally, estimated coefficients measure the unemployment impact of each policy and institution for the average country assuming that all other policy parameters - including other policies of the average country and policies and institutions of other countries - are kept constant. In other words, it cannot be excluded that estimated coefficients measure relative rather than absolute effects.

19. A negative sign implies that the detrimental effect of each policy indicator on unemployment is smaller the higher the other policy indicator, so that reforms diminishing the levels of these institutions should be undertaken together to maximise their impact. More formally, in equation [2] the partial derivative of unemployment with respect to the institutional indicator $\mathrm{X}^{k}$ is: $\partial U / \partial X^{k}=\beta_{k}+\gamma_{k h}\left(X_{i t}^{h}-\bar{X}^{h}\right)$. If $\gamma_{k h}$ is negative, the marginal unemployment effect of institution $X^{\mathrm{k}}$ will be larger (in algebraic terms) the lower the value of $\mathrm{X}^{h}$, i.e. the more employment-friendly is the other institution $\mathrm{X}^{h}$. In other words, the lower $\mathrm{X}^{h}$, the greater the potential employment gain from reforms reducing the level of $\mathrm{X}^{k}$.

20. The additional interactions that are included in an empirical model to meet the above conditions are called "implicit interactions" in the literature. More generally, in the absence of specific parameter restrictions suggested by the theory, for a reduced-form model with multiplicative interactions to be correctly specified, there should exist a partition of the set of institutions to be interacted with one another such that: i) all pairs of institutions identified by one included interaction are subsets of the sets belonging to the partition; and, ii) for each set belonging to the partition all interactions (with two or more terms) that can be generated with its elements are included into the model (see Braumoeller, 2004). 
21. Economic theory provides no clear-cut view on the mechanisms through which the bargaining regime shapes the employment impact of a given reform. For example, it has been argued that union bargaining power is lower in decentralised regimes, thereby lowering wage claims and making them less sensitive to employment conditions. Under this assumption, structural reforms are most effective in decentralised regimes (see e.g. Belot and van Ours, 2004). This is because the employment effects of any reform that shifts the wage-setting and/or the price-setting curve downwards are greater the flatter is the initial wage-setting curve (see Box 1 for a graphical exposition). By contrast, other authors (e.g. Calmfors and Driffill, 1988) argue that labour market insiders are most powerful in intermediate bargaining regimes. When insiders negotiate the wage, they tend to set the highest possible wage conditional on their own employment (see e.g. Bertola, 1999). As a consequence, except for high unemployment levels, wage claims are relatively independent from aggregate unemployment. The resulting flatness of the wage-setting curve implies that any structural reform that stimulates labour demand has greater employment effects than in other bargaining regimes.

22. Notice for comparison that the estimated effect of the tax wedge at the sample average is such that a 10 percentage point reduction of the tax wedge is estimated to reduce unemployment by 3.1 percentage points and this effect is reduced to only 2.1 percentage points in decentralised countries.

23. Hump-shaped patterns have been searched also for other institutions that affect the labour demand, such as product market regulation. Yet, no significant variation across regimes has been found.

24. For this reason, the remainder of this section will always consider interactions with only one - rather than two - wage-bargaining variable, namely a dummy for either high or low corporatism. When considering a dummy for high (low) corporatism, countries with intermediate bargaining regimes will be grouped into the low (high) corporatism group.

25. Although a high-corporatism dummy is already included in the institutional set, there is a case for also considering a low-corporatism dummy. In the baseline unemployment regression with country fixed effects, the estimated coefficient of the high-corporatism dummy can be readily interpreted as the effect of switching from low to high corporatism, because intermediate corporatist countries do not change regime within the estimation sample. This no longer holds when one incorporates interactions that include dichotomous variables. In such a case, the interpretation of the high- and low-corporatism dummy variables in simple interactions differs, because they imply different groupings of intermediate corporatist countries. Therefore, given that the correct grouping is unknown, interactions with low corporatism are not ruled out.

26. The latter variable is included in the institutional set because it is likely to capture union power more accurately than union density does. It takes value 1 when collective bargaining coverage exceeds $50 \%$ and zero otherwise. It is also time-invariant, which explains why a high collective bargaining coverage dummy variable is only informative in interactions and cannot be included in the baseline unemployment equation. While a purely quantitative measure of collective bargaining coverage would have done an even better job at capturing union power, no annual time series are available for such a variable in most countries (see OECD, 2004).

27. Interactions among dichotomous variables, as well as between union density and high collective bargaining coverage, are not shown here, as they are clearly difficult to interpret from either a statistic or economic point of view. 
28. The reason for including fixed effects rather than random effects relies on the fact that institutions are assumed to be correlated with country effects. This conjecture is also confirmed by Hausman tests on the baseline specification (see Bassanini and Duval, 2006). However, if an institution $X^{k}$ is correlated with a third time-invariant variable $X^{s}$, then the interaction between $X^{k}$ and any other variable $X^{h}$ (that is $X^{k} X^{h}$ ) will be correlated with $\mathrm{X}^{s} \mathrm{X}^{h}$. This implies that for at least one of the interactions of Table 3, OLS estimates are biased.

29. This can be viewed as a "quasi Hausman-Taylor" IV approach. Hausman and Taylor (1981) have noted that the deviation of a variable from its country-specific mean is a valid instrument for that variable in the absence of fixed effects, insofar as it is uncorrelated with any time-invariant unobservable factor. In the approach followed here, the necessary orthogonality conditions for the validity of the instrument are of the type $E\left(\left(X_{i t}^{k}-\bar{X}_{i}{ }^{k}\right)\left(X_{i t}^{h}-\bar{X}_{i}^{h}\right) X_{i}^{s} X_{i t}^{h}\right)=0$, where $\bar{X}_{i}^{j}$ stands for the country-specific mean of $X^{i}$ and $X_{i}^{s}$ for the time-invariant unobservable variable. These conditions are met if $E\left(\left(X_{i t}^{k}-\bar{X}_{i}^{k}\right) X_{i}^{s}\left(X_{i t}^{h}-\bar{X}_{i}^{h}\right)\right)=0$ and $E\left(\left(X_{i t}^{k}-\bar{X}_{i}^{k}\right) X_{i}^{s} \bar{X}_{i}^{h}\left(X_{i t}^{h}-\bar{X}_{i}^{h}\right)\right)=0$, which does not appear too stringent if one takes into account that the unconditional moments $E\left(\left(X_{i t}^{k}-\bar{X}_{i}^{k}\right) X_{i}^{s}\right)$ and $E\left(\left(X_{i t}^{k}-\bar{X}_{i}^{k}\right) X_{i}^{s} \bar{X}_{i}^{h}\right)$ are equal to zero by construction.

30. While consistent, this approach is likely to be more inefficient than the IV approach described above, due to excessive reduction of degrees of freedom.

31. Following the "rule of thumb" of Staiger and Stock (1997), the instrument is considered to be acceptable when the $\mathrm{F}$ test on the significance of the instrument is greater than 10 .

32. It might be argued that, if the convexity of the labour demand curve is one of the main sources of reform complementarity, negative interactions might disappear in a loglinear specification and/or quadratic terms of institutions should be included, too. Yet, repeating the exercise presented in Table 3 with log-linear specifications yields the same results (the interaction between the average replacement rate and union density is the only robust one), while no robustly significant quadratic term is found. As an additional sensitivity analysis, the baseline model has been estimated by augmenting it by all possible combinations of two interactions (including all implicit interactions, when applicable). Again, the interaction between the average replacement rate and union density turns out to be the only one significant in all specifications.

33. None of the specifications presented in Table 3 yields coefficients of the average effects substantially different from those obtained with the baseline model.

34. For an attempt at estimating "systemic" interactions while minimising the loss of degrees of freedom, see Bassanini and Duval (2006).

35. A few papers (e.g. Nickell et al., 2005) use annual time series for home ownership. However, they are obtained by interpolation of ten-year data. This choice is clearly not suited for the relatively short time span of the sample used for this study. For this reason, a more cautious empirical approach is adopted here (see below).

36. Countries with statutory minima during the whole sample period are Australia, Belgium, Canada, France, Japan, the Netherlands, New Zealand, Portugal, Spain and the United States. Ireland and the United Kingdom introduced a national minimum wage in 1999. They are not included in the sample, however, since their corresponding time series is too short. Results presented below, anyway, are robust to the inclusion of these two countries (even if the minimum wage is set to zero prior to the introduction of the statutory minimum). 
37. It might be argued that this result is due to the inclusion of country fixed effects insofar as most of the variation of the minimum wage ratio is cross-sectional, while its time-series variation is essentially due to movements of the median wage. Yet, this conjecture does not appear to be grounded in the data, insofar as the result presented in column 1 of Table 4 is robust to the exclusion of country and time effects from the specification.

38. Following the same approach as above (cf. Table 3), column 4 reports estimates obtained by two stage least squares where the interaction between the tax wedge and the minimum wage is instrumented with the product of the deviations of both variables from their respective country-specific means.

39. This corresponds to one standard deviation of the cross-country distribution of the ratio of minimum to median wages in 2003.

40. The motivation for this instrument is two-fold. First, regressing the ALMP indicator on a certain number of lags - three in the specifications reported in Table 5 - of the output gap plausibly eliminates the effect of contemporaneous and lagged cyclical fluctuations. Second, using lagged and differenced residuals is expected to remove the effect of once-off shifts in structural unemployment due to unobserved reforms. All the results discussed in this section are robust to different choices of instruments, such as reducing the number of lags of the output gap included in the preliminary regression, increasing the order at which the first-differenced residual is lagged and/or not differencing the residuals. The results are also robust to the exclusion of high ALMP-spending countries (Denmark, Sweden, Norway and the Netherlands) from the sample.

41. Following the same approach as before (cf. Table 3), column 4 reports estimates obtained by two stage least squares where the interaction is instrumented with the product of the deviation of the average replacement rate from its country-specific means and the lagged first difference of the residual of a regression of ALMP spending per unemployed as a percentage of GDP per capita on up to three lags of the output gap. Note that by definition the second term of this product is uncorrelated with country fixed effects.

42. Increasing ALMP expenditures per unemployed worker as a percentage of GDP per capita from the OECD average $(27.9 \%$ in 2000$)$ by 10 percentage points would reduce the coefficient of unemployment benefits by about one-fifth. Therefore if ALMP spending per unemployed were increased further to the level of Denmark (64.5\% of GDP per capita in 2000), the estimated impact of unemployment benefits on unemployment would be reduced by about two-thirds, making it insignificant.

43. System GMMs allow handling in more general terms the possible presence of an AR(1) component in the error term. Yet, GMMs are very sensitive to the specification and are inconsistent if the number of lags of the autoregressive component is not correctly specified. Additionally, given that the number of periods is as large as the number of countries, the same instruments are used at all lags in this case, which potentially increases the sensitivity of the estimator to specification errors. For this reason, GMM estimates are presented here only as a sensitivity exercise.

44. This is about one standard deviation of the country average of historical changes in the sample, excluding high-spending countries.

45. Care must be exerted, however, in drawing conclusions from the findings of Table 6. First, a potential source of bias in the estimates is that no account is made for the effectiveness of ALMP spending. For instance, a decline in the ratio of PES expenditures to GDP could well reflect an increase in efficiency through cuts in administrative costs 
rather than a decline in the "quality" of services provided to the unemployed. As a result, the lack of significance of ALMP categories other than training programmes does not necessarily imply that these are ineffective. Second, the results could be partly affected by the degree of consistency of the expenditure classification across countries. Third, programmes involving individual case management and mixed strategies might be classified as "training programmes", even though training constitutes only one of the components of the programme. Finally, workers on a training programme are often classified as inactive in labour force surveys and therefore cease being recorded as unemployed. As far as the latter caveat is concerned, it is useful to check whether the results presented in Table 6 hold when the employment rate is used as dependent variable, as is done in Bassanini and Duval (2006).

46. While shocks may have persistent effects on unemployment, not least via their interactions with policies and institutions, mainstream economic theory nevertheless suggests that the long-run unemployment effects of a permanent change in TFP, terms of trade, real interest rates and/or labour demand are likely to be either zero or small (see e.g. Blanchard and Katz, 1999).

47. Karanassou and Snower (1998) offer another theoretical model in which the presence of institutions that increase unemployment persistence also implies permanent unemployment effects of increased economic turbulence. In their model, labour demand and labour supply curves are continually drifting under the influence of new exogenous shocks, so that lagged adjustment processes towards a natural unemployment rate never have a chance to work themselves out entirely. As a result, the long-run equilibrium unemployment rate differs from the natural one, which can never be reached in a dynamic framework. The more persistent the employment level - due inter alia to existing institutions, the greater the gap between the long-run and the natural unemployment rate, and the greater its sensitivity to larger and/or more frequent shocks.

48. See, in particular, Drew et al. (2004) and Catte et al. (2004).

49. Amisano and Serrati (2003), Balakrishnan and Michelacci (2001), Balmaseda et al. (2000).

50. See e.g. Drew et al. (2004).

51. At a more basic level, the baseline unemployment regression in Table 1 also hints at the presence of such interactions. As already discussed, there is statistical evidence that estimates of the average unemployment effects of policies and institutions are consistent. However, this is not the case for the output gap variable, for which coefficient heterogeneity across countries is found to be very large. A possible explanation for this finding could be the existence of interactions between temporary macroeconomic shocks - which drive output and employment away from their equilibrium levels, as reflected in a negative output gap - and heterogeneous institutions - which explain cross-country differences in the reaction of unemployment to these shocks.

52. They obtain less significant results when using time-varying indicators of policies and institutions, however.

53. See Figure 1.

54. The only exception is the OECD measure of PMR in seven non-manufacturing industries, for which a time-varying indicator is therefore used over the period 1975-2003.

55. Ireland is an exception, for collective bargaining coverage data come from Belot and van Ours (2004). 
56. Obviously this would not be the case if the same IV strategy used above to control for omitted interactions were adopted. Yet, the implementation of that strategy is complex in the presence of non-linear specifications and is left for future research.

57. The periods considered are 1970-2003 for unemployment benefit average replacement rates and the index of corporatism, 1979-2003 for the tax wedge, 1980-2003 for collective bargaining coverage, 1982-2003 for EPL, and 1985-2003 for ALMPs where applicable. As already noted, an exception is made for PMR, for which a time-varying indicator for seven non-manufacturing industries is used. However, this indicator is not available before 1975. Therefore, the PMR indicator used here mixes a time-invariant component - equal to its 1975 value - over 1970-1975 with a time-varying one over 1975-2003.

58. As done in the previous section, interaction terms are specified in deviation form.

59. Throughout this section, the output gap is never included in the specifications insofar as the focus is on shocks.

60. An alternative selection procedure would be to consider all possible specifications with two interactions and: i) select those interactions that are always significant; ii) consider only specifications including the interactions selected at step (i) and consider all specifications with one additional interaction; iii) select those interactions that are significant at step (ii) and stop if no more than one is significant; otherwise iv) consider only specifications including the interactions selected at step (iii) and consider all specifications with one additional interaction; and select those interactions that are significant at step (iv) and stop if no more than one is significant; otherwise proceed in the same way until the final model is selected. With unobserved shocks, this selection procedure ends up with the same specification discussed above augmented by one interaction between collective bargaining coverage and shocks. However, when the selected specification is estimated with observed shocks or including the direct effect of institutions, the interaction between collective bargaining coverage and shocks becomes insignificant.

61. Previous analysis (Table 1) shows that even though these tax wedges are conceptually different, they can be used alternatively in panel data unemployment regressions without affecting the results.

62. To allow the usual interpretation of the direct effect of institutions, each shock variable is defined here as the deviation of that variable from its sample mean.

63. As before, the model is estimated by non-linear least squares. Since the model is dynamic, estimates suffer from the standard downward dependent variable bias (Nickell, 1981). However, the downward lagged dependent variable bias falls as the time span of the sample grows and it is less of a concern when the time span is large and of the same order of magnitude as the number of countries (Judson and Owen, 1999).

64. In the case of unemployment, the results may seem counterintuitive. A priori, high unemployment benefits would be expected to buffer the shock, while long-lasting benefits should slow down the adjustment via lower job search intensity. However, unemployment benefits may also impair wage flexibility and amplify the short-run effect of shocks via this channel.

65. However, the separate impact of EPL and PMR is difficult to disentangle insofar as they are highly correlated and interact with shocks through similar channels. In fact, the effect of these variables becomes somewhat less significant when they are simultaneously included. 


\section{BIBLIOGRAPHY}

Aghion, P. and P. Howitt (1994), "Growth and Unemployment", Review of Economic Studies, Vol. 61, No. 1 .

Algan, Y. and P. Cahuc (2004), "Job Protection: The Macho Hypothesis", IZA Discussion Papers No. 1192, Institute for the Study of Labor (IZA).

Amable, B. and. D. Gatti (2001), "The Impact of Product Market Competition on Employment and Wages", IZA Discussion Paper No. 276, March.

Amisano, G. and M. Serati (2003), "What Goes Up Sometimes Stays Up: Shocks and Institutions as Determinants of Unemployment Persistence", Scottish Journal of Political Economy, Vol. 50, No. 4.

Baccaro, L. and D. Rei (2005), "Institutional Determinants of Unemployment in OECD Countries: A Time series Cross-section Analysis (1960-98)", International Institute for Labor Studies Discussion Paper DP/160/2005, International Institute for Labor Studies, Geneva.

Baker, D., A. Glyn, D. Howell and J. Schmitt (2004), "Labor Market Institutions and Unemployment : A Critical Assessment of the Cross-Country Evidence", in D. Howell (ed.), Fighting Unemployment: The Limits of Free Market Orthodoxy, Oxford, Oxford University Press.

Balakrishnan, R. and C. Michelacci (2001), "Unemployment Dynamics Across OECD Countries", European Economic Review, Vol. 45, No. 1.

Ball, L. and R. Moffitt (2002), "Productivity Growth and the Phillips Curve", in A.B. Krueger and R. Solow (eds.), The Roaring Nineties: Can Full Employment be Sustained?, Russell Sage Foundation, New-York.

Balmaseda, M., J.J. Dolado and J.D. López-Salido (2000), "The Dynamic Effects of Shocks to Labour Markets: Evidence from OECD Countries", Oxford Economic Papers, Vol. 52, No. 1.

Bassanini, A. and R. Duval (2006), "Employment Patterns in OECD Countries: Reassessing the Role of Policies and Institutions", OECD Economics Department Working Paper, No. 486, June, and OECD Social, Employment and Migration Working Paper, No. 35.

Belot, M. and J. van Ours (2001), "Unemployment and Labor Market Institutions: An Empirical Analysis", Journal of the Japanese and International Economy, Vol. 15, No. 4.

Belot, M. and J. van Ours (2004), "Does the Recent Success of Some OECD Countries in Lowering their Unemployment Rates Lie in the Clever Design of their Labour Market Reform?", Oxford Economic Papers, Vol. 56, No. 4.

Bentolila, S. and J.J. Dolado (1994), “Labour Flexibility and Wages: Lessons from Spain”, Economic Policy, Vol. 18, April.

Bertola, G. (1999), “Aggregate Labor Markets”, in O. Ashenfelter and D. Card (eds.), Handbook of Labor Economics, Vol. 3C, North Holland, Amsterdam. 
Bertola, G., F. Blau and L. Kahn (2002), "Labor Market Institutions and Demographic Employment Patterns", NBER Working Paper No. 9043, July.

Betcherman, G., K. Olivas and A. Dar (2004), "Impacts of Active Labor Market Programs: New Evidence from Evaluations with Particular Attention to Developing and Transition Countries", World Bank Social Protection Discussion Paper, No. 0402, January.

Blanchard, O. (1998), "Revisiting European Unemployment: Unemployment, Capital Accumulation and Factor Prices", NBER Working Paper No. 6566, May.

Blanchard, O. (1999), "European Unemployment: The Role of Shocks and Institutions", Baffi Lecture, Rome, January.

Blanchard, O. (2000), "The Economics of Unemployment. Shocks, Institutions and Interactions", Lionel Robbins Lectures, London School of Economics, October.

Blanchard, O. and F. Giavazzi (2003), "Macroeconomic Effects of Regulations and Deregulation in Goods and Labour Markets", Quarterly Journal of Economics, Vol. 118, Issue 3, August.

Blanchard, O. and L. Katz (1999), "Wage Dynamics: Reconciling Theory and Evidence”, The American Economic Review, Vol. 89, No. 2.

Blanchard, O. and A. Landier (2002), "The Perverse Effects of Partial Labour Market Reform: Fixed-term Contracts in France", The Economic Journal, Vol. 112, No. 480, June.

Blanchard, O. and J. Wolfers (2000), "The Role of Shocks and Institutions in the Rise of European Unemployment: The Aggregate Evidence", The Economic Journal, Vol. 110, No. 462, March.

Boone, J. and J. van Ours (2004), “Effective Active Labor Market Policies”, IZA Discussion Paper, No. 1335, November.

Botero, J., S. Djankov, R. La Porta, F. Lopez de Silanes and A. Shleifer (2004), "The Regulation of Labor", Quarterly Journal of Economics, Vol. 119, No. 4, November.

Brandt, N., J.-M. Burniaux and R. Duval (2005), "Assessing the OECD Jobs Strategy: Past Developments and Reforms", OECD Economics Department Working Papers, No. 429, May.

Braumoeller, B. (2004), "Hypothesis Testing and Multiplicative Interaction Terms", International Organization, Vol. 58, Issue 4.

Bruno, M. and J. Sachs (1985), Economics of Worldwide Stagflation, Harvard University Press, Cambridge, Massachussets.

Cahuc, P. and F. Postel-Vinay (2002), "Temporary Jobs, Employment Protection and Labor Market Performance", Labour Economics, Vol. 9, No. 1.

Calmfors, L. (1993), "Centralisation of Wage Bargaining and Macroeconomic Performance: A Survey", OECD Economic Studies No. 21, Winter.

Calmfors, L. and J. Driffill (1988), "Bargaining Structure, Corporatism and Macroeconomic Performance", Economic Policy, No. 6, April.

Calmfors, L. and A. Forslund (1991), "Real Wage Determination and Labour Market Policies: The Swedish Experience", The Economic Journal, Vol. 105, No. 429.

Cameron, G. and J. Muellbauer (1998), "The Housing Market and Regional Commuting and Migration Choices", Scottish Journal of Political Economy, Vol. 45, No. 4.

Card, D. and A.B Krueger (1995), "Myth and Measurement: The New Economics of the Minimum Wage", Princeton University Press, Princeton, NJ. 
Carey, D. and J. Rabesona (2002), "Tax Ratios on Labour and Capital Income and on Consumption", OECD Economic Studies, No. 35, 2002/2.

Catte, P., N. Girouard, R. Price and C. André (2004), "Housing Markets, Wealth and the Business Cycle", OECD Economics Department Working Paper No. 394, June.

Coe, D.T. and D.J. Snower (1997), "Policy Complementarities: The Case for Fundamental Labour Market Reform,"IMF Staff Papers. Vol. 44, Issue 1, March.

Daveri, F. and G. Tabellini (2000), "Unemployment, Growth and Taxation in Industrial Countries", Economic Policy, No. 30.

Disney, R.F. (2004), "Are Contributions to Public Pension Programmes a Tax on Employment", Economic Policy, No. 39.

Dolado, J.J., C. Garcia-Serrano and J.F. Jimeno (2002), "Drawing Lessons From the Boom of Temporary Jobs in Spain", The Economic Journal, Vol. 112, No. 480, June.

Drew, A., M. Kennedy and T. Sløk (2004), “Differences in Resilience Between the Euro-Area and US Economies", OECD Economics Department Working Paper No. 382, March.

Ebell, M. and C. Haefke (2003), "Product market deregulation and labour market outcomes", Swiss National Bank Working Papers No. 02.08.

Elmeskov, J., J. Martin and S. Scarpetta (1998), “Key Lessons for Labour Market Reforms: Evidence from OECD Countries' Experiences", Swedish Economic Policy Review, Vol. 5, Issue 2, Autumn.

Estevao, M. (2003), “Do Active Labour Market Programmes Increase Employment?”, IMF Working Paper No. 03-234, December.

Fitoussi, J.P., D. Jestaz, E. Phelps and G. Zoega (2002), "Roots of the Recent Recoveries: Labor Reforms or Private Sector Forces?", Brookings Papers on Economic Activity 1:2000.

Fitoussi, J.P., F. Modigliani, B. Moro, D. Snower, R. Solow, A. Steinherr and P. Sylos Labini (1998), “An Economists' Manifesto on Unemployment in the European Union”, BNL Quarterly Review, 206.

Flanagan, R. (1999), "Macroeconomic Performance and Collective Bargaining: An International Perspective", Journal of Economic Literature, Vol. 37, No. 3, September.

Green, R.K. and P.H. Hendershott (2001), "Home-Ownership and Unemployment in the US", Urban Studies, Vol. 38, No. 9.

Hausman, J.A. and W.E. Taylor (1981), "Panel Data and Unobservable Individual Effects", Econometrica, Vol. 49.

Hawke, A. and M. Wooden (1998), "The Changing Face of Australian Industrial Relations", The Economic Record, Vol. 74, No. 224, March.

Heckman, J.J., R.J. Lalonde and J.A. Smith (1999), "The Economics and Econometrics of Active Labor Market Programs", in O. Ashenfelter and D. Card (eds.), Handbook of Labor Economics, Vol. 3A, North - Holland, Amsterdam.

International Monetary Fund (2003), “Unemployment and Labor Market Institutions: Why Reforms Pay Off", World Economic Outlook, Chapter IV, April.

Judson, R.A. and A.L. Owen (1999), "Estimating Dynamic Panel Data Models: A Guide for Macroeconomists", Economics Letters, Vol. 65, No. 1.

Karanassou, M. and D. Snower (1998), "How Labour Market Flexibility Affects Unemployment: Long-Term Implications of the Chain Reaction Theory", The Economic Journal, Vol. 108, No. 448, May. 
Kluve, J. and C. Schmidt (2002), "Can Training and Employment Subsidies Combat European Unemployment?", Economic Policy, No. 35.

Krueger, A.B. and J.S. Pischke (1997), "Observations and Conjectures on the US Employment Miracle", NBER Working Paper No. 6146, August.

La Porta, R., F. Lopez de Silanes, A. Shleifer and R. Vishny (1999), "The Quality of Government", Journal of Law, Economics and Organization, Vol. 15, Issue 1, April.

Layard, R., S. Nickell and R. Jackman (1991), Unemployment: Macroeconomic Performance and the Labour Market, Oxford University Press, Oxford.

Ljungqvist, L. and T.J. Sargent (1998), “The European Unemployment Dilemma”, Journal of Political Economy, Vol. 106, Issue 3.

Macculloch, R. and R. Di Tella (2002), "The Consequences of Labor Market Flexibility: Panel Evidence Based on Survey Data", Harvard NOM Research Paper No. 03-47.

Martin, J.P. and D. Grubb (2001), "What Works and for Whom: A Review of OECD Countries Experiences with Active Labour Market Policies,"Swedish Economic Policy Review, Vol. 8, No. 2.

McHugh, J. (2002), "Wage Centralization, Union Bargaining, and Macroeconomic Performance", IMF Working Paper 02/143, August.

Messina, J. (2003), "The Role of Product Market Regulation in the Process of Structural Change", European Central Bank, Working Paper Series No. 217, March.

Meyer, L.H. (2000), "The Economic Outlook and the Challenges Facing Monetary Policy", Remarks at the Century Club Breakfast Series, Research Memorandum, October 19th.

Neumark, D. and W. Wascher (1999), "A Cross-National Analysis of the Effects of Minimum Wages on Youth Employment", NBER Working Paper No. 7299, August.

Nickell, S. (1981), "Biases in Dynamic Models with Fixed Effects”, Econometrica, Vol. 49, No. 6.

Nickell, S. (1997), "Unemployment and Labor Market Rigidities: Europe versus North America", The Journal of Economic Perspectives, Vol. 11, No. 3.

Nickell, S. (1998), "Unemployment: Questions and Some Answers", The Economic Journal, Vol. 108, Issue 448, May.

Nickell, S. and R. Layard (1999), "Labor Market Institutions and Economic Performance”, in O. Ashenfelter and D. Card (eds.) Handbook of Labor Economics. Vol. 3C, North-Holland, Amsterdam.

Nickell, S., L. Nunziata and W. Ochel (2005), "Unemployment in the OECD Since the 1960s: What Do We Know?", The Economic Journal, Vol. 115, No. 500, January.

Nicoletti, G., R.C.G. Haffner, S. Nickell, S. Scarpetta and G. Zoega (2001), "European Integration, Liberalisation and Labour Market Performance", in G. Bertola, T. Boeri and G. Nicoletti (eds), Welfare and Employment in a United Europe, Cambridge, Mass.: The MIT Press.

Nicoletti, G. and S. Scarpetta (2005), "Product Market Reforms and Employment in OECD Countries", OECD Economics Department Working Paper, No. 472, December.

Nunziata, L. (2002), "Unemployment, Labour Market Institutions and Shocks", Nuffield College Working Papers in Economics 2002-W16.

OECD (1994), The OECD Jobs Study: Facts, Analyses, Strategies, Paris.

58 OECD (1997), Implementing the OECD Jobs Study: Lessons from Member Countries Experience, Paris.

$\overline{\text { C) OECD } 2006}$ 
OECD (1998), OECD Employment Outlook, June, Paris.

OECD (2002), OECD Employment Outlook, June, Paris.

OECD (2003), OECD Employment Outlook, June, Paris.

OECD (2004), OECD Employment Outlook, June, Paris.

OECD (2005), OECD Employment Outlook, June, Paris.

OECD (2006a), OECD Employment Outlook, June, Paris.

OECD (2006b), Boosting Jobs and Incomes: Policy Lessons from Re-Assessing the OECD Jobs Strategy, Paris.

Orszag, M. and D. Snower (1998), "Anatomy of Policy Complementarities"Swedish Economic Policy Review, Vol. 5.

Oswald, A.J. (1997), “Thoughts on NAIRU”, Journal of Economic Perspectives, Vol. 11.

Pencavel, J. (1999), "The Appropriate Design of Collective Bargaining Systems: Learning From the Experience of Britain, Australia, and New Zealand", Comparative Labour Law and Policy Journal, Vol. 20, No. 3, Spring.

Pesaran, H. and R. Smith (1995), "Estimating Long-Run Relationships from Dynamic Heterogenous Panels", Journal of Econometrics, Vol. 68, No. 1.

Pissarides, C. (2000), “Equilibrium Unemployment Theory", Cambridge, Massachusetts, MIT Press.

Pissarides, C. (2001), "Company Start-Up Costs and Employment", Centre for Economic Performance Discussion Paper No. 520, London School of Economics.

Pissarides, C. and G. Vallanti (2005), "The Impact of TFP Growth on Steady-State Unemployment", CEPR Discussion Paper No. 5002, January.

Scarpetta, S. (1996), "Assessing the Role of Labour Market Policies and Institutional Settings on Unemployment: A Cross-Country Study", OECD Economic Studies No. 26, 1996/1.

Siebert, H. (1997), "Labor Market Rigidities: At the Root of Unemployment in Europe", The Journal of Economic Perspectives, Vol. 11, No. 3.

Soskice, D. (1990), “Wage Determination: The Changing Role of Institutions in Advanced Industrialized Countries", Oxford Review of Economic Policy, Vol. 6, No. 4.

Spector, D. (2002), "Competition and the Capital-Labour Conflict", CEPREMAP Working Papers No. 2002-07.

Staiger, D. and J. Stock (1997), "Instrumental Variable Regression with Weak Instruments", Econometrica, Vol. 65, No. 3, May.

Traxler, F. (2000), "The Bargaining System and Performance: A Comparison of 18 OECD Countries", Comparative Political Studies, Vol. 33, No. 9, November.

Traxler, F., S. Blaschke and B. Kittel (2001), National Labour Relations in Internationalized Markets: A Comparative Study of Institutions, Change and Performance, Oxford: Oxford University Press. 


\section{Annex 1 \\ Theoretical Foundations and Previous Cross-country Empirical Evidence}

This annex reviews the main policies and institutions which have been identified as possible influences on structural unemployment according to both labour economic theory and past empirical studies (see Table Al for a survey of recent empirical results based on crosscountry time-series evidence). These include unemployment benefits, taxes, the role of trade unions and the structure of collective bargaining, employment protection legislation (EPL), product market regulation (PMR), active labour market policies (ALMPs) and minimum wages and determinants of home ownership.

\section{Unemployment benefits}

Relatively high unemployment benefits that are available for a relatively long duration can have adverse effects on labour market performance. In particular, such benefits may raise unemployment via two mechanisms: i) by reducing the job-search intensity of the unemployed and their willingness to accept job offers, benefits can weaken the job-matching process; and, ii) by lowering the economic cost of unemployment, they may put upward pressure on workers' wage claims and ultimately reduce vacancies and increase separations. ${ }^{1}$ Benefit eligibility conditions, monitoring of job search and sanctions also influence unemployment and wage outcomes.

On the other hand, unemployment benefits may allow jobseekers more time to find better matches, thereby lowering the likelihood of subsequent job separations and enhancing productivity. In addition, adequate income support for the unemployed is widely seen as being necessary for social reasons, cushioning the impact of job losses on living standards of the unemployed, and is also in some countries regarded as being a precondition for relatively light EPL. If the effects of unemployment benefits on job-search intensity and wage claims dominate the potentially favourable impact on the quality of job matches, a trade-off between equity and efficiency may arise. In empirical work, there is much evidence that various indicators of the level and duration of unemployment benefits have a significantly positive impact on unemployment (Scarpetta, 1996; Nickell, 1998; Elmeskov et al., 1998; Nunziata, 2002).

\section{Taxes}

It is generally accepted that payroll, personal income and consumption taxes have broadly similar effects on the wage-formation process and unemployment levels. ${ }^{2}$ What ultimately matters is the sum of these tax rates, i.e. the overall tax wedge between the cost of labour to employers and the consumption wage of workers. Whether this tax wedge permanently affects labour market outcomes is a priori unclear. Assuming a high degree of international mobility of 
Table A1. Reduced-form panel data estimates of the determinants of structural unemployment: findings from selected studies

\begin{tabular}{|c|c|c|c|c|}
\hline Study & $\begin{array}{l}\text { Period, data } \\
\text { frequency and } \\
\text { countries }\end{array}$ & Main determinants & $\begin{array}{l}\text { Interactions } \\
\text { considered }\end{array}$ & Findings \\
\hline $\begin{array}{l}\text { Baker, Glyn, } \\
\text { Howell and } \\
\text { Schmitt (2004) }\end{array}$ & $\begin{array}{l}\text { Independent } \\
\text { variable: } \\
\text { Aggregate } \\
\text { unemployment } \\
\text { rate. } \\
\text { Data: } \\
\text { 1960-1999, } \\
\text { 5-year } \\
\text { observations, } \\
20 \text { OECD countries. } \\
\text { Method: } \\
\text { FGLS random } \\
\text { effects, allowing for } \\
\text { heteroskedastic } \\
\text { errors. }\end{array}$ & $\begin{array}{l}\text { - Time-varying } \\
\text { measures of UB } \\
\text { RR and } \\
\text { duration, union } \\
\text { density and } \\
\text { coverage, co- } \\
\text { ordination, } \\
\text { wedge, and } \\
\text { EPL. } \\
\text { - Time-invariant } \\
\text { measure of } \\
\text { ALMP (average } \\
\text { over sample } \\
\text { period). } \\
\text { - Change in } \\
\text { inflation (proxy } \\
\text { for short-term } \\
\text { macroeconomic } \\
\text { situation). }\end{array}$ & $\begin{array}{l}\text { - }(\text { UB RR }) *(U B \\
\text { duration). } \\
\text { - }(\text { Union density) } \\
{ }^{*} \text { co-ordination } \\
\text { - Wedge * co- } \\
\text { ordination. }\end{array}$ & $\begin{array}{l}\text { When estimating Nickell's } \\
\text { (1997, 1998) equation over the } \\
\text { same period (1985-1994) but } \\
\text { using slightly different } \\
\text { (improved) data for } \\
\text { institutional variables, none of } \\
\text { these are found to be } \\
\text { significant. } \\
\text { - When a similar regression is } \\
\text { run over the whole 1960-1999 } \\
\text { period and also incorporates } \\
\text { interactions, a counter- } \\
\text { intuitive result is that UB RR } \\
\text { and duration significantly } \\
\text { reduce unemployment } \\
\text { provided their level is not } \\
\text { particularly high. EPL, union } \\
\text { density and wedge are found } \\
\text { to have no effect. Conversely, } \\
\text { co-ordination and interaction } \\
\text { between union density and } \\
\text { co-ordination have the } \\
\text { expected signs and are highly } \\
\text { significant. } \\
\text { - When the period 1960-1999 is } \\
\text { split into two sub-periods, } \\
\text { there is no consistency } \\
\text { between the results, e.g. UB } \\
\text { RR and duration are not } \\
\text { estimates found in the } \\
\text { literature. } \\
\text { co-ordination and interaction } \\
\text { between union density and } \\
\text { co-ordination are not } \\
\text { significant over 1960-1984, EPL } \\
\text { reduces unemployment } \\
\text { over interpreted } \\
\text { Thes }\end{array}$ \\
\hline
\end{tabular}


Table A1. Reduced-form panel data estimates of the determinants of structural unemployment: findings from selected studies (cont.)

\begin{tabular}{|c|c|c|c|c|}
\hline Study & $\begin{array}{l}\text { Period, data } \\
\text { frequency and } \\
\text { countries }\end{array}$ & Main determinants & $\begin{array}{l}\text { Interactions } \\
\text { considered }\end{array}$ & Findings \\
\hline $\begin{array}{l}\text { Belot and Van } \\
\text { Ours (2001) }\end{array}$ & $\begin{array}{l}\text { Independent } \\
\text { variable: } \\
\text { Aggregate } \\
\text { unemployment } \\
\text { rate. } \\
\text { Data: } \\
\text { 1960-1995, annual, } \\
\text { 18 OECD countries. } \\
\text { Method: } \\
\text { OLS fixed effects }\end{array}$ & $\begin{array}{l}\text { - Time-varying } \\
\text { measures of UB } \\
\text { RR, union } \\
\text { density and } \\
\text { coverage, co- } \\
\text { ordination, } \\
\text { wedge, and } \\
\text { EPL. } \\
\text { - Change in } \\
\text { inflation (proxy } \\
\text { for short-term } \\
\text { macroeconomic } \\
\text { situation). }\end{array}$ & $\begin{array}{l}\text { - All possible } \\
\text { interactions } \\
\text { between the six } \\
\text { institutional } \\
\text { determinants of } \\
\text { unemployment } \\
\text { (institutions) } \\
\text { considered. }\end{array}$ & $\begin{array}{l}\text { - The tax wedge is highly } \\
\text { significant. UB RR, union } \\
\text { density and union coverage } \\
\text { are significant in most (but not } \\
\text { all) regressions. The unusual } \\
\text { negative sign found for union } \\
\text { coverage is interpreted as a } \\
\text { proxy for the effect of the } \\
\text { degree of centralisation in } \\
\text { wage bargaining. EPL reduces } \\
\text { unemployment in some } \\
\text { regressions, but is insignificant } \\
\text { in the majority of them. } \\
\text { Co-ordination is almost never } \\
\text { significant. } \\
\text { Interactions matter: most (but } \\
\text { not all) of them are significant } \\
\text { and consistent with the } \\
\text { underlying theoretical model } \\
\text { presented in the paper } \\
\text { (although not always with the } \\
\text { rest of the literature). In } \\
\text { particular, a "restrictive" set of } \\
\text { labour market policies (e.g. } \\
\text { high UB RR, tax wedge, union } \\
\text { density) reduces the } \\
\text { effectiveness of a given, } \\
\text { isolated reform (e.g. high union } \\
\text { density, which leads to higher } \\
\text { unemployment, reduces the } \\
\text { favourable impact of reducing } \\
\text { unemployment benefits on } \\
\text { the unemployment rate). }\end{array}$ \\
\hline
\end{tabular}


Table A1. Reduced-form panel data estimates of the determinants of structural unemployment: findings from selected studies (cont.)

\begin{tabular}{|c|c|c|c|c|}
\hline Study & $\begin{array}{l}\text { Period, data } \\
\text { frequency and } \\
\text { countries }\end{array}$ & Main determinants & $\begin{array}{l}\text { Interactions } \\
\text { considered }\end{array}$ & Findings \\
\hline $\begin{array}{l}\text { Bertola, Blau } \\
\text { and Kahn } \\
(2002)\end{array}$ & $\begin{array}{l}\text { Independent } \\
\text { variable: } \\
\text { Aggregate } \\
\text { unemployment } \\
\text { rate, youth } \\
\text { unemployment } \\
\text { rate. } \\
\text { Data: } \\
\text { 1960-1995/96, } \\
\text { 5-year } \\
\text { observations, } \\
\text { 20 OECD countries. } \\
\text { Method: } \\
\text { OLS fixed effects } \\
\text { for specifications } \\
\text { without } \\
\text { interactions. } \\
\text { - Non-linear least } \\
\text { squares when } \\
\text { interactions are } \\
\text { considered. }\end{array}$ & $\begin{array}{l}\text { - Common, } \\
\text { unobservable, } \\
\text { macroeconomic } \\
\text { shocks: time } \\
\text { fixed effects. } \\
\text { - Country- } \\
\text { specific, } \\
\text { observable, } \\
\text { macroeconomic } \\
\text { shocks: TFP } \\
\text { growth, real } \\
\text { interest rate, } \\
\text { labour demand } \\
\text { shift, change in } \\
\text { inflation, } \\
\text { demographic } \\
\text { shock (proxied } \\
\text { by youth share } \\
\text { in total } \\
\text { population). } \\
\text { Institutions: } \\
\text { time-invariant } \\
\text { measures of UB } \\
\text { RR and } \\
\text { duration, ALMP, } \\
\text { EPL, wedge, } \\
\text { union density } \\
\text { and coverage, } \\
\text { co-ordination; } \\
\text { time-varying } \\
\text { measures of UB } \\
\text { RR, EPL, union } \\
\text { density and } \\
\text { coverage, co- } \\
\text { ordination. }\end{array}$ & $\begin{array}{l}\text { - } \text { (Common } \\
\text { shocks) }{ }^{*} \text { (time } \\
\text { invariant } \\
\text { institutions). } \\
\text { - } \text { (Common } \\
\text { shocks) }{ }^{*} \\
\text { (time-varying } \\
\text { institutions). } \\
\text { - (Country- } \\
\text { specific shocks) } \\
\text { * (time invariant } \\
\text { institutions). } \\
\text { - (Country- } \\
\text { specific shocks) } \\
\text { * (time-varying } \\
\text { institutions). }\end{array}$ & $\begin{array}{l}\text { - All observable shocks are } \\
\text { significant with expected } \\
\text { signs in the baseline } \\
\text { specification, except the } \\
\text { youth share. Less } \\
\text { unfavourable shocks in the } \\
\text { United States than in Europe } \\
\text { have contributed to some } \\
\text { extent to diverging } \\
\text { unemployment trends across } \\
\text { both sides of the Atlantic. } \\
\text { However, interactions matter } \\
\text { more than shocks per se: a } \\
\text { model with interactions } \\
\text { between shocks and time- } \\
\text { invariant institutions } \\
\text { explains a significantly larger } \\
\text { share of the divergence than } \\
\text { a model with shocks only } \\
\text { (50\% vs. } 11 \% \text { ). } \\
\text { This questions the robustness of } \\
\text { simulations using these models. } \\
\text { institutions have contributed } \\
\text { to some extent to diverging } \\
\text { unemployment trends, but } \\
\text { interactions matter more } \\
\text { than institutions per se: a } \\
\text { model with interactions } \\
\text { between shocks and time- } \\
\text { varying institutions explains } \\
\text { a larger share of the } \\
\text { divergence than a model } \\
\text { with shocks and institutions } \\
\text { entered separately (63\% vs. } \\
\text { - Ho\%). } \\
\text { (except those including } \\
\text { unemployment benefit } \\
\text { duration and, to a lesser } \\
\text { extent, EPL) are insignificant } \\
\text { in regressions with time- } \\
\text { instiant institutions, and } \\
\text { ang ones. }\end{array}$ \\
\hline
\end{tabular}


Table A1. Reduced-form panel data estimates of the determinants of structural unemployment: findings from selected studies (cont.)

\begin{tabular}{|c|c|c|c|c|}
\hline Study & $\begin{array}{l}\text { Period, data } \\
\text { frequency and } \\
\text { countries }\end{array}$ & Main determinants & $\begin{array}{l}\text { Interactions } \\
\text { considered }\end{array}$ & Findings \\
\hline $\begin{array}{l}\text { Blanchard and } \\
\text { Wolfers (2000) }\end{array}$ & $\begin{array}{l}\text { Independent } \\
\text { variable: } \\
\text { Aggregate } \\
\text { unemployment } \\
\text { rate, structural } \\
\text { unemployment } \\
\text { rate. } \\
\text { Data: } \\
\text { 1960-1995/96, } \\
\text { 5-year } \\
\text { observations, } \\
\text { 20 OECD countries. } \\
\text { Method: } \\
\text { OLS fixed effects } \\
\text { for specifications } \\
\text { without } \\
\text { interactions. } \\
\text { - Non-linear least } \\
\text { squares when } \\
\text { interactions are } \\
\text { considered. }\end{array}$ & $\begin{array}{l}\text { - Common, unobservable, } \\
\text { macroeconomic shocks: } \\
\text { time fixed effects. } \\
\text { - Country-specific, } \\
\text { observable, } \\
\text { macroeconomic shocks: } \\
\text { TFP growth, real interest } \\
\text { rate, labour demand } \\
\text { shift. } \\
\text { - Institutions: time- } \\
\text { invariant measures of UB } \\
\text { RR and duration, ALMP, } \\
\text { EPL, wedge, union } \\
\text { density and coverage, } \\
\text { co-ordination; time- } \\
\text { varying measures of UB } \\
\text { RR and EPL. }\end{array}$ & $\begin{array}{l}\text { - } \text { (Common } \\
\text { shocks) }{ }^{*} \text { (time } \\
\text { invariant } \\
\text { institutions). } \\
\text { - (Common } \\
\text { shocks) }{ }^{*} \\
\text { (time-varying } \\
\text { institutions). } \\
\text { - (Country- } \\
\text { specific shocks) } \\
\text { * (time } \\
\text { invariant } \\
\text { institutions). } \\
\text { - (Country- } \\
\text { specificshocks) } \\
\text { * (time-varying } \\
\text { institutions). }\end{array}$ & $\begin{array}{l}\text { - Shocks account for } \\
\text { most of the general } \\
\text { evolution of } \\
\text { unemployment over } \\
\text { the last decades. } \\
\text { - Interactions between } \\
\text { shocks and } \\
\text { institutions account } \\
\text { for most of the } \\
\text { heterogeneity of } \\
\text { unemployment } \\
\text { evolutions over the } \\
\text { sample period. } \\
\text { - Most interacted terms } \\
\text { are significant (except } \\
\text { those including union } \\
\text { coverage), i.e. } \\
\text { institutions contribute } \\
\text { to determining the } \\
\text { final impact of a given } \\
\text { shock on } \\
\text { unemployment. } \\
\text { - When time-varying } \\
\text { (as opposed to time- } \\
\text { invariant) measures of } \\
\text { EPL and UB RR are } \\
\text { used, the results are } \\
\text { significantly weaker. }\end{array}$ \\
\hline $\begin{array}{l}\text { Boone and } \\
\text { Van Ours } \\
(2004)\end{array}$ & $\begin{array}{l}\text { Independent } \\
\text { variable: } \\
\text { Aggregate } \\
\text { unemployment } \\
\text { and non- } \\
\text { employment rates. } \\
\text { Data: } \\
\text { 1985-1999, annual } \\
\text { and 5-year } \\
\text { averages, } 19 \text { OECD } \\
\text { countries. } \\
\text { Method: } \\
\text { OLS fixed effects } \\
\text { and FGLS Random } \\
\text { effects. }\end{array}$ & $\begin{array}{l}\text { Time-varying measures } \\
\text { of UB generosity, union } \\
\text { density as well as shares } \\
\text { of each ALMP category in } \\
\text { total ALMP (fixed effects } \\
\text { specifications) or time- } \\
\text { invariant measures of } \\
\text { ALMPs (average over } \\
\text { sample period) by } \\
\text { category in random } \\
\text { effect specifications. } \\
\text { - Other institutions } \\
\text { mentioned but not } \\
\text { shown (authors argue } \\
\text { they are not significant). } \\
\text { - Change in inflation } \\
\text { (proxy for short-term } \\
\text { macroeconomic } \\
\text { situation). }\end{array}$ & $\begin{array}{l}\text { - UB generosity * } \\
\text { ALMP training. }\end{array}$ & $\begin{array}{l}\text { - UB and union density } \\
\text { are negative and } \\
\text { significant. } \\
\text { - Labour market } \\
\text { training is found to be } \\
\text { the most effective } \\
\text { programme to bring } \\
\text { down unemployment, } \\
\text { public employment } \\
\text { services have some } \\
\text { impact while } \\
\text { subsidised jobs are } \\
\text { not effective at all. } \\
\text { - UB generosity and } \\
\text { labour market training } \\
\text { are found to be } \\
\text { complementary. }\end{array}$ \\
\hline
\end{tabular}


Table A1. Reduced-form panel data estimates of the determinants of structural unemployment: findings from selected studies (cont.)

\begin{tabular}{|c|c|c|c|}
\hline Study & $\begin{array}{l}\text { Period, data } \\
\text { frequency and } \\
\text { countries }\end{array}$ & Main determinants & $\begin{array}{l}\text { Interactions } \\
\text { considered }\end{array}$ \\
\hline $\begin{array}{l}\text { Daveri and } \\
\text { Tabellini } \\
(2000)\end{array}$ & $\begin{array}{l}\text { Independent } \\
\text { variable: } \\
\text { Aggregate } \\
\text { unemployment rate, } \\
\text { first difference in } \\
\text { aggregate } \\
\text { unemployment rate. } \\
\text { Data: } \\
\text { 1965-1995, 5-year } \\
\text { observations, } \\
\text { 14 OECD countries. } \\
\text { Method: } \\
\text { - OLS fixed effects } \\
\text { in basic } \\
\text { specifications with } \\
\text { unemployment } \\
\text { level as } \\
\text { dependent } \\
\text { variable. } \\
\text { - OLS or GLS in } \\
\text { alternative } \\
\text { specifications with } \\
\text { change in } \\
\text { unemployment as } \\
\text { dependent } \\
\text { variable. }\end{array}$ & $\begin{array}{l}\text { - Time-varying } \\
\text { measures of } \\
\text { labour tax rate } \\
\text { (defined as the tax } \\
\text { wedge excluding } \\
\text { consumption } \\
\text { taxes), UB } \\
\text { generosity and } \\
\text { EPL. }\end{array}$ & $\begin{array}{l}\text { - (Labour tax rate) } \\
* \text { (strength of } \\
\text { unions in wage } \\
\text { bargaining and } \\
\text { degree of } \\
\text { centralisation/ } \\
\text { co-ordination). } \\
\text { - NB: in practice } \\
\text { countries are } \\
\text { classified into } \\
3 \text { groups: } \\
\text { 1) weak unions } \\
\text { (whatever the } \\
\text { degree of } \\
\text { centralisation/ } \\
\text { co-ordination); } \\
\text { 2) strong unions } \\
\text { with highly } \\
\text { centralised or } \\
\text { co-ordinated } \\
\text { bargaining; } \\
\text { 3) strong unions } \\
\text { with low or } \\
\text { intermediate } \\
\text { degree of } \\
\text { centralisation/ } \\
\text { co-ordination. }\end{array}$ \\
\hline
\end{tabular}

Findings

- In all specifications, the impact of the labour tax rate is consistent with theory: very large (compared with other studies) and significant in countries with high union power and low/ intermediate degree of centralisation/ co-ordination in bargaining, small (and even insignificant in regressions in first differences) where union power is low, and insignificant where unions are powerful but the degree of centralisation/ co-ordination is high.

- When the dependent variable considered is the level of unemployment, the coefficient on UB generosity is positive and significant at 5\% level, and that of EPL is negative and significant at $10 \%$ level. Both become insignificant in regressions in first differences.

- The consumption tax rate has no effect on unemployment when entered separately in any specification. This suggests that only the labour-related component of the tax wedge matters for unemployment. 
Table A1. Reduced-form panel data estimates of the determinants of structural unemployment: findings from selected studies (cont.)

\begin{tabular}{|c|c|c|c|c|}
\hline Study & $\begin{array}{l}\text { Period, data } \\
\text { frequency and } \\
\text { countries }\end{array}$ & Main determinants & $\begin{array}{l}\text { Interactions } \\
\text { considered }\end{array}$ & Findings \\
\hline $\begin{array}{l}\text { Elmeskov, } \\
\text { Martin and } \\
\text { Scarpetta } \\
\text { (1998) }\end{array}$ & $\begin{array}{l}\text { Independent } \\
\text { variable: } \\
\text { Aggregate } \\
\text { unemploy- } \\
\text { ment rate. } \\
\text { Data: } \\
\text { 1983-1995, } \\
\text { annual, } \\
19 \text { OECD } \\
\text { countries. } \\
\text { Method: } \\
\text { FGLS random } \\
\text { effects. }\end{array}$ & $\begin{array}{l}\text { - Time-varying } \\
\text { measures of UB } \\
\text { generosity, } \\
\text { union density, } \\
\text { co-ordination, } \\
\text { centralisation, } \\
\text { wedge (and } \\
\text { EPL over } \\
\text { 1989-1995). } \\
\text { - Time-invariant } \\
\text { measure of } \\
\text { ALMP (average } \\
\text { over sample } \\
\text { period). } \\
\text { - Other } \\
\text { variables: } \\
\text { minimum } \\
\text { wage. } \\
\text { - Control } \\
\text { variables: } \\
\text { output gap. }\end{array}$ & $\begin{array}{l}\text { - }(\text { UB } \\
\text { generosity) * } \\
\text { ALMP. } \\
\text { - } \text { (UB } \\
\text { generosity) * } \\
\text { EPL. } \\
\text { - EPL * } \\
\text { corporatism. } \\
\text { - Wedge * } \\
\text { corporatism. } \\
\end{array}$ & $\begin{array}{l}\text { - UB generosity, high corporatism, } \\
\text { co-ordination and wedge are highly } \\
\text { significant, centralisation (consistent with } \\
\text { hump-shaped hypothesis) and EPL to a } \\
\text { lesser extent; mixed evidence regarding } \\
\text { ALMP. } \\
\text { - No significant effect of union density and } \\
\text { minimum wage. } \\
\text { - Detrimental effects of EPL and wedge are } \\
\text { larger in countries with intermediate } \\
\text { degree of corporatism (consistent with } \\
\text { hump-shaped hypothesis); detrimental } \\
\text { impact of UB generosity is not affected by } \\
\text { tightness of EPL, and is larger when ALMP } \\
\text { is low. }\end{array}$ \\
\hline $\begin{array}{l}\text { International } \\
\text { Monetary } \\
\text { Fund (2003) }\end{array}$ & $\begin{array}{l}\text { Independent } \\
\text { variable: } \\
\text { Aggregate } \\
\text { unemploy- } \\
\text { ment rate. } \\
\text { Data: } \\
\text { 1960-1998, } \\
\text { annual, } \\
20 \text { OECD } \\
\text { countries. } \\
\text { Method: } \\
\text { fixed effects } \\
\text { FGLS, } \\
\text { dynamic } \\
\text { panel. }\end{array}$ & $\begin{array}{l}\text { - Country- } \\
\text { specific, } \\
\text { observable } \\
\text { macro- } \\
\text { economic } \\
\text { shocks: labour } \\
\text { productivity } \\
\text { growth, real } \\
\text { interest rate, } \\
\text { terms of trade. } \\
\text { - Institutions: } \\
\text { time-varying } \\
\text { measures of UB } \\
\text { generosity, } \\
\text { union density, } \\
\text { co-ordination, } \\
\text { wedge, EPL. } \\
\text { Other } \\
\text { variables: } \\
\text { degree of } \\
\text { central bank } \\
\text { independence. }\end{array}$ & $\begin{array}{l}\text { - All possible } \\
\text { interactions } \\
\text { between the } \\
\text { five } \\
\text { institutional } \\
\text { determinants } \\
\text { of unemploy- } \\
\text { ment } \\
\text { (institutions) } \\
\text { considered. }\end{array}$ & $\begin{array}{l}\text { - Labour productivity growth and real } \\
\text { interest rate shocks are highly significant. } \\
\text { Significance of terms of trade shock varies } \\
\text { across specifications. } \\
\text { - EPL, union density and tax wedge are } \\
\text { highly significant, as well as co-ordination } \\
\text { (evidence in favour of the "hump- } \\
\text { shaped" hypothesis). UB generosity is } \\
\text { significant only when no country-specific } \\
\text { time-trends are included in the } \\
\text { regression. } \\
\text { - Several interactions between institutions } \\
\text { have a significant impact on aggregate } \\
\text { unemployment. The most robust ones } \\
\text { across different specifications of the } \\
\text { estimated equation are (EPL) * (union } \\
\text { density) and (wedge) * (union density), } \\
\text { both of which are negatively signed. } \\
\text { - Central bank independence tends to raise } \\
\text { unemployment. This effect is mitigated } \\
\text { when bargaining co-ordination is high. } \\
\text { - Adjustment speed towards equilibrium } \\
\text { unemployment is reduced by UB } \\
\text { generosity and bargaining co-ordination. } \\
\text { Institutions account for cross-country } \\
\text { differences in unemployment but less so } \\
\text { for the trend rise in European } \\
\text { unemployment. In this respect, shocks } \\
\text { also appear to have played a major role. }\end{array}$ \\
\hline
\end{tabular}


Table A1. Reduced-form panel data estimates of the determinants of structural unemployment: findings from selected studies (cont.)

\begin{tabular}{|c|c|c|c|c|}
\hline Study & $\begin{array}{l}\text { Period, data } \\
\text { frequency and } \\
\text { countries }\end{array}$ & Main determinants & $\begin{array}{l}\text { Interactions } \\
\text { considered }\end{array}$ & Findings \\
\hline $\begin{array}{l}\text { Nickell } \\
\text { (1997, 1998) }\end{array}$ & $\begin{array}{l}\text { Independent } \\
\text { variable: } \\
\text { Log (aggregate } \\
\text { unemployment } \\
\text { rate), } \\
\text { log (short-term } \\
\text { unemployment } \\
\text { rate), } \\
\text { log (long-term } \\
\text { unemployment } \\
\text { rate). } \\
\text { Data: } \\
\text { 1983-1994, two } \\
\text { 6-year } \\
\text { observations } \\
\text { (1983-88 } \\
\text { and 1989-94), } \\
\text { 20 OECD countries. } \\
\text { Method: } \\
\text { FGLS random } \\
\text { effects. }\end{array}$ & $\begin{array}{l}\text { - Time-varying } \\
\text { measures of UB RR } \\
\text { and duration, union } \\
\text { density and } \\
\text { coverage, } \\
\text { co-ordination, wedge, } \\
\text { EPL, ALMP } \\
\text { (instrumented). } \\
\text { - Change in inflation } \\
\text { (proxy for short-term } \\
\text { macroeconomic } \\
\text { situation). } \\
\text { - Owner occupation } \\
\text { rate (proxy for } \\
\text { barriers to regional } \\
\text { mobility, used only in } \\
\text { Nickell, 1998). }\end{array}$ & & $\begin{array}{l}\text { - UB RR, union density and } \\
\text { coverage, co-ordination, ALMP } \\
\text { (more so for the long-term } \\
\text { unemployed only in Nickell, 1997) } \\
\text { and wedge all have a highly } \\
\text { significant impact on aggregate } \\
\text { unemployment. UB duration is } \\
\text { significant for total and long-term } \\
\text { unemployment in Nickell (1998), } \\
\text { but only for the latter in Nickell } \\
\text { (1997). } \\
\text { - No significant effect of EPL on } \\
\text { aggregate unemployment, but } \\
\text { negative impact on aggregate } \\
\text { employment (however, zero } \\
\text { impact when females are } \\
\text { excluded). }\end{array}$ \\
\hline $\begin{array}{l}\text { Nickell, } \\
\text { Nunziata } \\
\text { and Ochel } \\
(2005)\end{array}$ & $\begin{array}{l}\text { Independent } \\
\text { variable: } \\
\text { Aggregate } \\
\text { unemployment } \\
\text { rate 1961-1992 } \\
\text { or 1961-1995 } \\
\text { depending on } \\
\text { specifications. } \\
\text { Data: } \\
\text { annual, } 20 \text { OECD } \\
\text { countries. } \\
\text { Method: } \\
\text { FGLS random } \\
\text { effects, dynamic } \\
\text { panel allowing for } \\
\text { heteroskedastic } \\
\text { errors and country- } \\
\text { specific first order } \\
\text { serial correlation. }\end{array}$ & $\begin{array}{l}\text { - Common, } \\
\text { unobservable, } \\
\text { macroeconomic } \\
\text { shocks: time fixed } \\
\text { effects. } \\
\text { - Country-specific, } \\
\text { observable shocks: } \\
\text { change in TFP growth, } \\
\text { change in real import } \\
\text { prices, real interest } \\
\text { rate, change in } \\
\text { money supply growth } \\
\text { (proxy for aggregate } \\
\text { demand shock), } \\
\text { labour demand shift. } \\
\text { - Institutions: time- } \\
\text { varying measures of } \\
\text { UB RR and duration, } \\
\text { change in union } \\
\text { density, } \\
\text { co-ordination, wedge, } \\
\text { EPL. } \\
\text { Owner occupation } \\
\text { rate (proxy for } \\
\text { barriers to regional } \\
\text { mobility). } \\
\text { Country-specific time } \\
\text { trends. }\end{array}$ & $\begin{array}{l}\text { - }\left(\text { UB RR) }{ }^{*}(\text { UB }\right. \\
\text { duration). } \\
\text { - (Union } \\
\text { density) }{ }^{*} \\
\text { co-ordination. } \\
\text { - } \text { Wedge }^{*} \\
\text { co-ordination. } \\
\text { - } \text { (Common }^{\text {(Comocks) }}{ }^{*} \\
\text { (time } \\
\text { invariant } \\
\text { institutions) } \\
\text { in some } \\
\text { specifications. } \\
\end{array}$ & $\begin{array}{l}\text { - Labour demand, TFP and real } \\
\text { import price shocks are highly } \\
\text { significant, unlike money supply } \\
\text { shock. Statistical significance of } \\
\text { real interest rate shock varies } \\
\text { across specifications } \\
\text { - UB RR and co-ordination are } \\
\text { highly significant. UB duration and } \\
\text { wedge are significant in most (but } \\
\text { not all) regressions, while EPL is } \\
\text { not. } \\
\text { - All interactions between } \\
\text { institutions have a highly } \\
\text { significant impact on aggregate } \\
\text { unemployment, consistent with } \\
\text { theory: (UB RR) * (UB duration), } \\
\text { (union density) * co-ordination, } \\
\text { wedge * co-ordination. } \\
\text { Changes in institutions explain a } \\
\text { sizeable share of the rise in } \\
\text { European unemployment over } \\
\text { the sample period: } 55 \% \text {, two thirds } \\
\text { of which stem from increases in UB } \\
\text { RR, UB duration and tax wedges. } \\
\text { The high significance of } \\
\text { interactions between common } \\
\text { shocks and time-invariant } \\
\text { institutions found by Blanchard } \\
\text { and Wolfers (2000) vanishes when } \\
\text { one controls for changes in } \\
\text { institutions. }\end{array}$ \\
\hline
\end{tabular}


Table A1. Reduced-form panel data estimates of the determinants of structural unemployment: findings from selected studies (cont.)

\begin{tabular}{|c|c|c|c|c|}
\hline Study & $\begin{array}{l}\text { Period, data } \\
\text { frequency and } \\
\text { countries }\end{array}$ & Main determinants & $\begin{array}{l}\text { Interactions } \\
\text { considered }\end{array}$ & Findings \\
\hline $\begin{array}{l}\text { Nicoletti } \\
\text { and } \\
\text { Scarpetta } \\
(2004)\end{array}$ & $\begin{array}{l}\text { Independent } \\
\text { variable: } \\
\text { Aggregate } \\
\text { employment } \\
\text { rate in the non- } \\
\text { agricultural } \\
\text { business sector. } \\
\text { Data: } \\
\text { 1980-2002, } \\
\text { annual, } \\
20 \text { OECD } \\
\text { countries. } \\
\text { Method: } \\
\text { fixed effects. }\end{array}$ & $\begin{array}{l}\text { - Time-varying } \\
\text { measures of public } \\
\text { employment rate, } \\
\text { UB generosity, } \\
\text { union density, } \\
\text { co-ordination, } \\
\text { centralisation; EPL, } \\
\text { PMR } \\
\text { - In certain } \\
\text { specifications: LMR } \\
\text { (principal } \\
\text { component of UB, } \\
\text { EPL and tax wedge) } \\
\text { and Inst (principal } \\
\text { component of union } \\
\text { density, } \\
\text { centralisation and } \\
\text { co-ordination) } \\
\text { - Control variables: } \\
\text { output gap, } \\
\text { country-time trends }\end{array}$ & $\begin{array}{l}\text { - Lmr * PMR } \\
\text { - EPL* } \\
\text { corporatism. }\end{array}$ & $\begin{array}{l}\text { - UB generosity, union density, PMR, } \\
\text { EPL have significantly negative } \\
\text { coefficients in all regressions, } \\
\text { - Evidence of an hump-shaped effect of } \\
\text { corporatism. } \\
\text { - The estimated effect of EPL is entirely } \\
\text { due to countries with an intermediate } \\
\text { level of corporatism. } \\
\text { - The effect of PMR is found to be more } \\
\text { negative in countries with stricter LMR. }\end{array}$ \\
\hline $\begin{array}{l}\text { Nunziata } \\
\text { (2002) }\end{array}$ & $\begin{array}{l}\text { Independent } \\
\text { variable: } \\
\text { Aggregate } \\
\text { unemployment } \\
\text { rate. } \\
\text { Data: } \\
\text { 1960-1995, } \\
\text { annual, } \\
20 \text { OECD } \\
\text { countries. } \\
\text { Method: } \\
\text { fixed effects, } \\
\text { FGLS, dynamic } \\
\text { panel allowing } \\
\text { for } \\
\text { heteroskedastic } \\
\text { errors and } \\
\text { country-specific } \\
\text { first order serial } \\
\text { correlation. }\end{array}$ & $\begin{array}{l}\text { - Common, } \\
\text { unobservable, } \\
\text { macroeconomic } \\
\text { shocks: time fixed } \\
\text { effects. } \\
\text { - Country-specific, } \\
\text { observable, } \\
\text { macroeconomic } \\
\text { shocks: change in } \\
\text { TFP growth, change } \\
\text { in real import } \\
\text { prices, real interest } \\
\text { rate, change in } \\
\text { money supply } \\
\text { growth (proxy for } \\
\text { aggregate demand } \\
\text { shock), labour } \\
\text { demand shift. } \\
\text { - Institutions: time- } \\
\text { invariant and time- } \\
\text { varying measures of } \\
\text { UB RR and } \\
\text { duration, EPL, } \\
\text { wedge, union } \\
\text { density and } \\
\text { co-ordination. } \\
\text { Other variables: } \\
\text { fixed term contracts } \\
\text { regulation, owner } \\
\text { occupation rate. }\end{array}$ & $\begin{array}{l}\text { - }\left(\text { UB RR) }{ }^{*}(\text { UB }\right. \\
\text { duration). } \\
\text { - (Union } \\
\text { density) }{ }^{*} \\
\text { co-ordination. } \\
\text { - } \text { Wedge }^{*} \\
\text { co-ordination. } \\
\text { - (Common } \\
\text { shocks) }{ }^{*} \\
\text { (time } \\
\text { invariant } \\
\text { institutions). } \\
\text { - (Common } \\
\text { shocks) }{ }^{*} \\
\text { (time-varying } \\
\text { institutions). } \\
\text { - (Country- } \\
\text { specific } \\
\text { shocks) }{ }^{*} \\
\text { (time } \\
\text { invariant } \\
\text { institutions). } \\
\text { (Country- } \\
\text { specific } \\
\text { shocks) }{ }^{*} \\
\text { (time-varying } \\
\text { institutions). } \\
\end{array}$ & $\begin{array}{l}\text { - Labour demand, TFP and real import } \\
\text { price shocks are highly significant, } \\
\text { unlike money supply shock. Statistical } \\
\text { significance of real interest rate shock } \\
\text { varies across specifications. } \\
\text { - UB RR is highly significant; UB } \\
\text { duration, co-ordination and change in } \\
\text { (but not level of) union density are } \\
\text { significant in most estimates, wedge in } \\
\text { some of them. Fixed-term contract } \\
\text { regulations raise unemployment. } \\
\text { - EPL does not affect unemployment } \\
\text { levels but increases unemployment } \\
\text { persistence. } \\
\text { - Interactions between institutions are } \\
\text { significant with expected signs: (UB } \\
\text { RR) }{ }^{*} \text { (UB duration), (union density) }{ }^{*} \\
\text { co-ordination and, to a lesser extent, } \\
\text { wedge * co-ordination. } \\
\text { - Changes in institutions explain a } \\
\text { sizeable share of the rise in European } \\
\text { unemployment over the sample } \\
\text { period: } 55 \% \text {, much of the remainder } \\
\text { being due to the direct effect of shocks. } \\
\text { - Some interactions between shocks } \\
\text { and institutions (including UB RR and } \\
\text { duration) have a significant effect in a } \\
\text { number of specifications. However, } \\
\text { their contribution to past } \\
\text { unemployment trends is generally } \\
\text { found to be low compared with the } \\
\text { direct effect of changes in institutions. }\end{array}$ \\
\hline
\end{tabular}


Table Al. Reduced-form panel data estimates of the determinants of structural unemployment: findings from selected studies (cont.)

\begin{tabular}{|c|c|c|c|c|}
\hline Study & $\begin{array}{l}\text { Period, data } \\
\text { frequency and } \\
\text { countries }\end{array}$ & Main determinants & $\begin{array}{l}\text { Interactions } \\
\text { considered }\end{array}$ & Findings \\
\hline $\begin{array}{l}\text { Scarpetta } \\
\text { (1996) }\end{array}$ & $\begin{array}{l}\text { Independent } \\
\text { variable: } \\
\text { Aggregate, } \\
\text { youth and LTU } \\
\text { unemployment } \\
\text { rates, as well as } \\
\text { aggregate non- } \\
\text { employment } \\
\text { rate. } \\
\text { Data: } \\
\text { 1983-1993, } \\
\text { annual, 15 to } \\
17 \text { OECD } \\
\text { countries } \\
\text { depending on } \\
\text { specifications. } \\
\text { Method: } \\
\text { FGLS random } \\
\text { effects. }\end{array}$ & $\begin{array}{l}\text { Time-varying } \\
\text { measures of UB } \\
\text { generosity, union } \\
\text { density, } \\
\text { co-ordination, } \\
\text { centralisation; } \\
\text { time-invariant } \\
\text { measures of EPL } \\
\text { (1989 value) and } \\
\text { ALMP (average } \\
\text { over sample } \\
\text { period). } \\
\text { - Other variables : } \\
\text { time-varying } \\
\text { measures of } \\
\text { wedge, real } \\
\text { interest rate, terms } \\
\text { of trade, } \\
\text { pervasiveness of } \\
\text { trade restrictions } \\
\text { (proxy for product } \\
\text { market } \\
\text { competition). } \\
\text { Control variables: } \\
\text { output gap. }\end{array}$ & $\begin{array}{l}\text { - } \text { (Union } \\
\text { density) }^{*} \\
\text { co-ordination } \\
\text { - } \text { (Union } \\
\text { density) }{ }^{*} \\
\text { centralisation }\end{array}$ & $\begin{array}{l}\text { - UB generosity, union density and } \\
\text { co-ordination are highly significant in } \\
\text { all regressions, as well as EPL } \\
\text { (especially for youth and LTU) when } \\
\text { no centralisation variable is included; } \\
\text { significant impact of centralisation, } \\
\text { consistent with hump-shaped } \\
\text { hypothesis; mixed evidence } \\
\text { regarding ALMP. } \\
\text { - No significant effect of other } \\
\text { individual variables (except wedge } \\
\text { for LTU, and trade restrictions for LTU } \\
\text { and non-employment). } \\
\text { - (Union density) * co-ordination is } \\
\text { significant with the expected } \\
\text { negative sign. } \\
\text { - Dynamic equation, estimated using } \\
\text { non-linear SUR estimators, shows } \\
\text { that adjustment speed towards } \\
\text { equilibrium unemployment is } \\
\text { reduced by UB generosity, strict EPL } \\
\text { and union density. Impact of } \\
\text { centralisation on speed of } \\
\text { adjustment is consistent with hump- } \\
\text { shaped hypothesis. }\end{array}$ \\
\hline
\end{tabular}

\section{Notations:}

UB RR: unemployment benefits' replacement rate.

UB generosity: a combination of UB RR and duration.

Wedge: tax wedge, i.e. the gap between the cost of labour to the employer and the employee's take-home pay.

LTU: long-term unemployed.

SUR: seemingly unrelated regression.

OLS: ordinary least squares.

FGLS: feasible generalised least squares.

EPL: index for employment protection legislation.

ALMP: an indicator of active labour market policies.

EPL: employment protection legislation.

UB duration: duration of unemployment benefits.

PMR: product market regulation. 
capital in the long run, real labour costs depend only on exogenous financial (the real cost of capital) and technological (the level of technological progress) factors (the so-called "factorprice frontier"). In a perfectly competitive labour market, workers would be expected to bear the entire tax burden through lower net wages, leaving equilibrium unemployment unchanged. However, this may not be the case in practice, provided that the following three conditions are met:

- The labour market must be imperfect, in the sense that wages can be set above market-clearing levels.

- Workers must, at least to some extent, bargain over net - as opposed to gross - wages, which in turn assumes that they prefer higher direct wages over indirect benefits financed by taxes. This assumption is most likely to be true for taxes and charges that are not paid in exchange for direct government provision of goods, services and transfers to the individual taxpayer. Personal income taxes clearly fall into that category, together with indirect taxes levied on goods and services. However, it is less clear how contributions to public social security schemes should be treated. To the extent that they are perceived by employees as giving rights to future transfers, they would resemble compulsory savings or insurance contributions more than a tax, with a potentially very different impact on employees' incentives to supply labour. As a result, it is difficult in practice to divide social security contributions into taxes, compulsory saving and insurance premia. ${ }^{3}$

- Along the same lines, no institutional constraint must prevent shifting the tax burden onto wages. For instance, in the presence of a binding legal minimum wage, an increase in employers' contribution rates to social security raise the minimum cost of labour, with possible adverse effects on labour demand (see below).

- Finally, the reservation wage - defined as the minimum wage level required in order to prefer work to unemployment - must be affected proportionally less than the wage by an increase in the tax wedge. As underlined for instance by Blanchard (1999), components of the reservation wage include not only unemployment benefits but also other sources of economic welfare that are much less likely to be influenced by the tax wedge, such as leisure, household production, black market activities or non-labour income.

However, theory provides clearer guidance for minimum wage workers: insofar as a rise in payroll taxes can not be shifted onto them, it puts pressure on labour costs and reduces employment.

A number of empirical studies have found that high labour taxes tend to increase unemployment rates (Belot and van Ours, 2004; Nickell, 1997), although other studies are less conclusive (Scarpetta, 1996; Nunziata, 2002; Macculloch, and DiTella, 2002). Daveri and Tabellini (2000) find a particularly strong impact in countries with powerful trade unions and a low or intermediate degree of centralisation/co-ordination of the wage bargaining process, and Elmeskov et al. (1998) also find notably large effects in countries with intermediate centralisation/co-ordination. These studies conclude that such an environment allows trade unions to compensate for higher taxes by successfully pushing for higher wages. ${ }^{4}$

\section{Trade unions and the structure of collective bargaining}

Strong trade unions have the ability to push wages above market-clearing levels, at the cost of lower employment. Furthermore, according to Bertola, Blau and Kahn (2002), the job losses incurred may fall primarily on those groups whose labour supply is most elastic, e.g. youth, women and older workers who often have more alternatives to paid employment compared with prime-age males. ${ }^{5}$ However, it has long been argued that, in practice, union 
influence on wage formation varies depending on the structure of collective bargaining (see e.g. Traxler, 2000):

- Decentralised wage bargaining at the firm level has often been regarded as employment-friendly, preventing excessive wage claims since this would lead to a loss of market shares to competitors with detrimental effects on employment. Also, a major effect of collective bargaining is to harmonise working conditions across workers, with possible negative consequences on employment (Siebert, 1997). For instance, the compressed wage structure (across qualification levels) that is usually associated with centralisation/co-ordination may price a number of low-skilled workers out of work (Calmfors, 1993). Similarly, insufficient wage flexibility at the regional level can maintain pockets of high unemployment in the presence of limited geographical mobility. ${ }^{6}$

- On the other hand, very centralised or co-ordinated bargaining systems are more likely to lead to wage moderation, because they induce unions to internalise the detrimental effects - e.g. on employment - that excessive wage pressure may have at the macroeconomic level. Centralisation/co-ordination also facilitates implicit or explicit "social pacts" under which unions agree to restrain wage demands in exchange for policy concessions from the government. Under this approach, there is a positive relationship between the degree of centralisation/co-ordination, or "corporatism", ${ }^{7}$ and overall employment performance (Bruno and Sachs, 1985; Soskice, 1990).

- These considerations suggest that the relationship between employment and the degree of corporatism may not be monotonic but rather "hump-shaped" (Calmfors and Driffill, 1988): intermediate systems based on branch-level bargaining without higherlevel co-ordination yield the worst labour market outcomes, as they benefit neither from the internalisation of negative externalities associated with centralised/co-ordinated systems nor from the market discipline that prevails at the decentralised level. Indeed, when bargaining takes place at the firm level (without co-ordination), the high elasticity of demand in the product market implies that any price increase resulting from higher wages would result in severe output and job losses. Enterprise-based unions are thus unlikely to exploit their market power to secure higher wages. By contrast, unions which bargain at the industry level have more room to secure higher wages because product demand elasticity is generally lower - as there are unlikely to be as many close substitutes as at the firm level. ${ }^{8}$ Intermediate level bargaining may particularly emerge, with detrimental effects on employment, in the presence of legal extensions of sectoral collective agreements which reduce the scope for domestic competition to moderate wage demands (Box Al).

While certain studies have found support for the "hump-shaped" hypothesis (Elmeskov et al., 1998; Scarpetta, 1996), the empirical literature remains inconclusive overall (for a survey, see Flanagan, 1999).

\section{Employment protection legislation}

In the presence of EPL, firms incur costs when dismissing workers. As a result, they may offer lower wages in order to compensate for these firing costs. At the same time, because they are better protected against dismissals, incumbent workers have more bargaining power and demand higher wages. Resulting wage tensions lead firms to reduce hiring rates, which in turn mechanically increases the average time job seekers have to spend in unemployment before finding a new job. As unemployment becomes more costly to workers, they are more willing to accept lower wages to maintain their jobs, and labour market equilibrium is restored (Blanchard, 1999). ${ }^{9}$ Therefore, theory clearly predicts that EPL lowers labour turnover 


\section{Box A1. The labour market effects of legal extension mechanisms}

Legal extension procedures, by which collective agreements become partially (e.g. minimal provisions) or fully binding on parties which were originally nonsignatories, were identified as potentially damaging for labour market performance within the context of the original 1994 Jobs Study. Concerns about extension mechanisms of collective agreements at the branch level are three-fold:

- They purposefully harmonise working conditions across firms within the sector concerned. Doing so, they prevent wages from reflecting local - firm level and/or geographical - conditions, notably local productivity levels. As a result, least productive firms and workers are likely to be priced out of product and labour markets, while most productive firms enjoy rents as they do not have to pay higher wages.

- They remove an important restraint on unions' wage demands, namely the need to avoid pricing their members out of work. Knowing that their wages will be imposed on non members through statutory extension, they are likely to raise their claims, at the cost of lower employment.

- The very existence of statutory extension provisions stimulates membership in employer federations, as individual employers are likely to prefer to influence the terms of negotiated agreements rather than having them dictated by competing firms. Therefore, multi employer agreements are likely to be more frequent when extension mechanisms exist, i.e. the degree of centralisation in wage bargaining is likely to be higher. To the extent that there is some validity in the "hump shaped" hypothesis, sectoral bargaining (without co-ordination) may be detrimental to labour market performance (and to economic performance more broadly) compared with decentralised wage setting.

The table below, based on a quantitative indicator of extension procedures recently constructed by the OECD (Brandt et al., 2004), sums up the importance of extension mechanisms in a number of OECD countries. These appear to be mainly available in continental European countries, with the exception of Nordic countries (but including Finland). Some functional equivalent for statutory extension still exists in Australia through the role played by the "arbitration system" in setting minimal provisions at the sectoral level (Hawke and Wooden, 1998; OECD, 2004). However, its influence has been significantly reduced over the past decade following the 1993 Industrial Relations Reform Act. Another OECD country which has undergone major changes in legal extension procedures during the 1990s is New-Zealand, where the 1991 Employment Contract Act terminated a long-standing tradition of extensions (see for instance Pencavel, 1999).

Almost by definition, the importance of extension mechanisms is a powerful determinant of variations in the level of bargaining coverage across countries. Here, the cross-country correlation between the quantitative index of extension procedures presented in Brandt et al. and excess union coverage (the difference between the rate of collective bargaining coverage and trade union density) is found to be significant at the $1 \%$ level. ${ }^{1}$ This suggest that for given union density, ${ }^{2}$ legal extension mechanisms tend to increase coverage, thereby providing more bargaining power to negotiating unions. 
Box A1. The labour market effects of legal extension mechanisms (cont.)

Legal extension of sectoral collective agreements in selected OECD countries

\begin{tabular}{llll}
\hline & Inexistent & Limited & Important \\
\hline Importance of extension & Canada & Australia & Austria \\
mechanisms & Denmark & Germany & Belgium \\
& Japan & Greece & Finland \\
& New Zealand & Ireland & France \\
Norway & Switzerland & Italy \\
& Sweden & & Luxembourg \\
& United Kingdom & & Netherlands \\
& United States & & Portugal \\
& & & Spain \\
\hline
\end{tabular}

Source: OECD, see Brandt et al. (2004) for details.

There is also some preliminary indication that statutory extension mechanisms contribute to shape the structure of collective bargaining. To investigate this issue, two dummy variables are constructed in a cross-country dimension. One dummy variable takes the value 1 if legal extension procedures exist in the country and 0 otherwise, and the other takes the value 1 if bargaining at the intermediate level plays an important role $^{3}$ and 0 otherwise. The correlation between these two dummy variables (over a sample of 22 countries) is found to be significant at the $1 \%$ level, suggesting that statutory extension devices indeed stimulate bargaining at the industry level.

1. For other, recent evidence along these lines, see Traxler et al. (2001).

2. However, legal extension procedures also provide lower incentives for employees to join unions, as the application of the terms of negotiated agreements to workers does no longer hinge on union membership.

3. This corresponds to countries where the OECD centralisation index takes the values 2 or 3 for the year 2000 (see OECD, 2004), i.e. to countries where industry-level bargains are either concomitant with company/plant level agreements or predominant.

(both hiring and layoff) on the one hand, but increases the length of unemployment spells on the other hand, with ambiguous net effects on aggregate employment and unemployment rates. Econometric estimates of the impact of EPL on the unemployment rate do not clearly settle the matter. ${ }^{10}$

However, by reducing turnover, the job prospects for those with relatively weak attachment to the labour market, such as young workers and women, have been found to be compromised (OECD 2004). As well, given that the probability to find a job increases with 
turnover, the incidence of long-term unemployment is likely to be boosted by restrictive EPL. The low turnover associated with strict EPL may also hamper the effectiveness of the Public Employment Service and other active labour market policies (ALMPs) aiming at reintegrating unemployed workers in the labour market. Moreover, if wages are not sufficiently flexible to allow high dismissal costs to be reflected in lower wages, e.g. due to wage floors, the job prospects of low-wage workers may be adversely affected. On the other hand, some degree of EPL may counteract the emergence of implicit agreements between workers and firms in industries subject to greater demand volatility to intensively use intermittent jobspells and unemployment insurance as part of the remuneration in what is in fact a continuous employment relationship.

It has also been argued that in a setting where extensive employment protection for workers with permanent contracts coexists with lighter regulation for temporary contracts, wage pressure and therefore unemployment may increase to the extent that unions pursue mainly the interests of permanent workers (Bentolila and Dolado, 1994). The argument behind this is that "insiders" on permanent contracts can raise their wage claims without much risk of job losses as any resulting negative effects on employment will be borne mainly by the "outsiders" who work on temporary contracts. Moreover, deregulated temporary contracts may merely increase the turnover in this segment of the labour market - potentially implying disincentives to train the concerned workers - without constituting a stepping stone to more permanent work relationships, as long as these remain costly to dissolve (Blanchard and Landier, 2002; Cahuc and Postel-Vinay, 2002). These arguments have raised concerns that a deregulation of EPL focused on temporary contracts may not improve labour market performance (Dolado et al., 2002).

\section{Product market regulation}

A growing body of recent literature ${ }^{11}$ supports the view that competition in product markets can have an impact on labour market performance. For instance, lower barriers to entry curb market power and rents of incumbents and make entry of new firms possible. Both these effects tend to expand activity levels and labour demand. Moreover, lower product market rents usually translate into lower wage claims, tending to close the gap between productivity and real wages that generates unemployment. Increased competition as a result of product market reforms will also boost real wages via lower prices, even if this effect may be attenuated somewhat if wages prior to reforms contain a large rental element that is reduced as intensified competition lowers product market rents and thereby the scope for rent sharing. The increase in real wages will stimulate labour supply and employment. Furthermore, an increase in product market competition is likely to result in changes in the functioning of the labour market with repercussions for employment and unemployment. Stronger competition may harden the bargaining position of employers and increase the employment costs of pushing for higher wages, thereby leading to lower unemployment. Reduced incidence and extent of rent sharing would also tend to reduce "wait unemployment" as it would become less attractive to prolong and limit search for employment opportunities in "highwage" sectors.

While these effects will tend to reduce unemployment and boost employment in the long run, there could be significant short-term adjustment problems. This is because weak competition forces in product markets not only spill over into wages but also to productivity levels as rents are taken out as "quiet life" and "x-inefficiency". Under these circumstances, increased competition may result in a labour shake-out. Whether the shake-out is absorbed quickly or leads to a protracted increase in joblessness and a drop in employment rates is 
not clear-cut, however. On the one hand, by enhancing resource reallocation through a process of creative destruction, greater competition accelerates any reshuffling process in the labour market, thereby raising equilibrium employment levels. On the other hand, certain institutions that defer the necessary adjustments may lengthen the transition process. This may occur, for instance, when unemployment and related benefits are linked to past wages, including any rent components, thus making unemployment and other forms of inactivity financially attractive compared with wages that are not artificially boosted by rents.

\section{Active labour market policies}

Properly designed ALMPs - which typically consist of job placement services and labour market programmes such as job-search, vocational training or hiring subsidies - can reduce unemployment by improving the efficiency of the job matching process and by enhancing the work experience and skills of the unemployed. Linking eligibility criteria for unemployment insurance to participation in ALMP programmes can also increase pre-programme jobsearch effort (OECD, 2003). In practice, however, the effectiveness of ALMPs has been found to differ significantly between different types of programmes. In particular, the outcomes of public job creation and wage subsidy programmes, which often entail large dead-weight losses (subsidised jobs are created that would have been created even without the subsidy) and substitution effects (workers who qualify for a subsidy replace others who do not), have often been disappointing in terms of bringing the unemployed back into to unsubsidised work (Martin and Grubb, 2001). Furthermore, any beneficial effects of ALMPs need to be weighted against the costs of taxes required to finance them, which may in turn increase unemployment. Moreover, certain programmes may reduce search efforts, if not properly designed, and in the case where participation in ALMPs represents a more attractive alternative than open unemployment (financially or possibly with respect to the stigma associated with alternatives), they can augment wage demands (Calmfors and Forslund, 1991).

Empirical macroeconomic studies generally find a negative effect of ALMP spending on aggregate unemployment but fail to agree on its magnitude (e.g. Scarpetta, 1996; Nickell, 1997, 1998; Nickell and Layard, 1999; Boone and van Ours, 2004). Microeconomic studies find a positive impact for some types of programmes, but not for others (see Heckman et al., 1999, Martin and Grubb, 2001, Kluve and Schmidt, 2001, Betchermann et al., 2004). When proper account is made for the long-run impact of ALMPs on job attachment, ${ }^{12}$ intensive employment services, individual case management and mixed strategies with selective referrals to long-term programmes are found to have the largest impact. In any event, apparently similar programmes can yield widely different outcomes, so that detailed programme design is key (OECD, 2005).

\section{Minimum wages}

In a perfectly competitive labour market, a minimum wage set above the market-clearing level reduces labour demand and thus raises unemployment. In particular, least productive categories of workers are priced out of employment, and possibly of the labour force if, as in the case of youth or low-skilled women, their attachment to the labour market is weaker. However, there is no longer such a clear cut answer once account is made for firms' monopsony power. In such a case, employers have some discretion in wage-setting because workers cannot easily find a job elsewhere (for such reasons as imperfect information on job vacancies or low geographical mobility). Under such circumstances, a rise in the minimum wage reduces unemployment up to a certain point and starts to increase it thereafter. ${ }^{13}$ The main lesson from alternative representations of the functioning of labour markets ${ }^{14}$ is that minimum 
wages need to be set at sufficiently low levels in order to minimise their potential negative impact on employment.

\section{Incentives to mobility and housing policy}

Labour mobility within and across firms may play an important role in reducing regional employment imbalances and assuring a rapid allocation of labour to most productive jobs, thereby increasing the overall efficiency of the job matching process. The literature on this issue has particularly focussed on the potential obstacles to mobility induced by existing housing policies (e.g. Oswald, 1997). Since housing costs (mortgage payments or rents) are typically the largest component of households' budgets, decisions to change residence in order to take up a new job are likely to be influenced by housing market conditions and housing policies. In general, homeowners are less likely to migrate than renters. Therefore, ceteris paribus, the larger the tax incentives and subsidies to home ownership, the higher the share of home owners relative to renters and the lower the geographical mobility, all the more so if transaction costs (legal procedures, taxes, real-estate fees) are high (Catte et al., 2004; OECD, 2005). 


\section{Notes}

1. Furthermore, benefits need to be financed by taxes which in turn may bear a negative impact on employment (see below).

2. See for instance the summary in Nickell (1997).

3. Disney (2004) attempts to divide contributions into tax and premia contributions.

4. The likely implications of different wage bargaining systems for wage claims are discussed in more detail below.

5. These alternative activities are respectively education, household production and retirement.

6. McHugh (2002) also suggests that the greater the degree of centralisation, the more unions are able to put pressure on authorities for granting a favourable legal environment for their activities, i.e. the more powerful they are in wage bargaining.

7. The degree of corporatism combines two dimensions: $i$ ) the level of bargaining: centralised, intermediate (at the branch or regional level) or decentralised (at the firm level); and, ii) the degree of co-ordination among, on the one hand, trade unions and, on the other hand, employer associations. This latter dimension of corporatism allows considering cases where co-ordination at the industry level is functionally equivalent to centralised systems, thereby mimicking their outcomes.

8. For instance, there are arguably fewer substitutes for clothes as a whole than for a particular brand of clothes. However this argument does not take into account the impact of foreign competition, which in practice also limits the ability of industry-level unions to exploit their market power.

9. For more comprehensive analysis of EPL effects on labour market outcomes, see OECD (2004).

10. Scarpetta (1996) and Elmeskov et al. (1998) find a positive effect in some of their estimated equations, while Nickell (1997) and Nunziata (2002) find no significant effect.

11. See Krueger and Pischke (1997), Amable and Gatti (2001), Pissarides (2001), Spector (2002), Blanchard and Giavazzi (2003); Messina (2005); Ebell and Haefke (2003).

12. Micro-evaluation studies often have short post-programme observation windows and fail to capture the effect of ALMPs on post-programme job attachment. This is especially an issue for programmes that aim at increasing job-match quality, such as those with some training content. In fact, these programmes tend to fare better the longer the observation window (OECD, 2005). Similarly, general equilibrium effects are often not accounted for in microeconometric studies (Boone and van Ours, 2004).

13. More precisely, starting from the equilibrium wage rate in a monopsonistic labour market, a rise in the minimum wage reduces the "monopsonistic rent" of employers and 
increases employment levels until it reaches the level that would prevail in a perfectly competitive labour market. A rise in the minimum wage beyond this competitive level will then start to reduce employment. In practice, however, an appropriate minimum wage level is hard to determine, because it depends on a wide range of factors including the actual functioning of labour markets and labour demand and supply elasticities.

14. For a survey of other theoretical models - such as efficiency wage models - in which a rise in the minimum wage may reduce unemployment under certain conditions and up to a certain level, see OECD (1998). 


\section{Annex 2 \\ Data Construction and Sources}

\section{Unemployment rate}

Definition: unemployed (employed) workers as share of the labour force (working-age population), in \%. Aggregate rates refer to the 15-64 age group.

Source: OECD, Database on Labour Force Statistics; OECD, Annual Labour Force Statistics.

Data adjustments: while the primary source is the OECD Database on Labour Force Statistics, Annual Labour Force Statistics - which are usually available over longer time periods - were also used in some cases to extrapolate (un)employment rates backwards (under the assumption of similar percentage changes in unemployment and employment rates in both sources). Missing observations are obtained by linear interpolation when possible.

\section{Policy and institutional indicators}

\section{Average unemployment benefit replacement rate:}

Definition: average gross replacement rate across two income situations (100\% and $67 \%$ of APW earnings), three family situations (single, with dependent spouse, with spouse in work) and three different unemployment durations (1st year, 2nd and 3rd years, and 4th and 5 th years of unemployment).

Source: OECD, Benefits and Wages Database.

Data adjustments: original data are available only for odd years. Data for even years are obtained by linear interpolation.

\section{Initial (first year) unemployment benefit replacement rate:}

Definition: average gross replacement rate during the first year of unemployment across two income situations (100\% and $67 \%$ of APW earnings) and three family situations (single, with dependent spouse, with spouse in work).

Source: OECD, Benefits and Wages Database.

Data adjustments: original data are available only for odd years. Data for even years are obtained by linear interpolation.

\section{Unemployment benefit duration:}

Definition: ratio of average to initial unemployment benefit replacement rates (see above). 


\section{Tax wedge:}

Definition: tax wedge between the labour cost to the employer and the corresponding net take-home pay of the employee for a single-earner couple with two children earning $100 \%$ of APW earnings. The tax wedge expresses the sum of personal income tax and all social security contributions as a percentage of total labour cost.

\section{Source: OECD, Taxing Wages.}

Data adjustments: Austria: original data include employers' social security contributions starting from 1997 only, thereby inducing an upward shift in tax wedge from this year; the tax wedge starting from 1997 is therefore recalculated based on the fact that employers' contribution rates to social security remained unchanged between 1996 and 1997. Netherlands: unlike other years, in 2002 and 2003 APW earnings are just above the threshold beyond which employers and employees do no longer have to contribute to the national health insurance plan (private medical insurance is typically provided instead), thereby inducing a temporary decline in the tax wedge; this issue is addressed by replacing the 2002 and 2003 observations by data obtained from linear interpolations between the 2001 and 2004 observations.

\section{Tax wedge derived from National Accounts:}

Definition: combined labour and consumption tax rate derived from National Accounts. Compared with labour tax wedges simulated by tax models - such as those published in Taxing Wages, the main advantage of tax wedges derived from National Accounts is to incorporate consumption taxes. A number of other differences exist between the Taxing Wages calculations and those based on National Accounts. ${ }^{1}$ In particular:

While differences in population structure (e.g. income distribution or demographics) affect implicit average effective tax wedges derived from National Accounts, they have no impact on the Taxing Wages calculations. From this standpoint, the latter are thus more comparable across countries as they refer to similar family situations. On the other hand, the Taxing Wages calculations may not accurately reflect the situation of very low and very high income individuals.

Implicit average effective tax wedges are based on "real" data and thus reflect all the factors that influence the amount of taxes actually paid. By contrast, the Taxing Wages calculation takes no account of observed data but instead is based on calculations for a small number of different "typical" families. The extent to which these "typical families" are representative of the population of actual taxpayers will usually differ across countries.

Unlike tax wedges derived from National Accounts, data published in Taxing Wages incorporate family benefits.

The timing of changes in tax wedges may differ across sources. This is because revenue statistics are computed on a cash basis while tax wedges published in Taxing Wedges reflect the tax rules that prevail for the year considered.

Source: Carey D. and J. Rabesona (2002), "Tax Ratios on Labour and Capital Income and on Consumption", OECD Economic Studies No. 35, 2002/2; Carey D. (2003), "Tax Reform in Belgium", OECD Economics Department Working Paper No. 354, May. The calculations made by these authors are based in turn on OECD Revenue Statistics and OECD National Accounts. 


\section{Labour and consumption tax rates:}

Definition: components of the overall tax wedge derived from National Accounts (see above).

\section{Employment Protection Legislation (EPL):}

Definition: OECD summary indicator of the stringency of Employment Protection Legislation.

Source: OECD, Employment Outlook 2004.

\section{Product Market Regulation (PMR):}

Definition: OECD summary indicator of regulatory impediments to product market competition in seven non-manufacturing industries. The data used in this paper ${ }^{2}$ cover regulations and market conditions in seven energy and service industries: gas, electricity, post, telecoms (mobile and fixed services), passenger air transport, railways (passenger and freight services) and road freight.

Source: Conway, P., D. De Rosa, G. Nicoletti, and F. Steiner (2006), "Regulation, competition, and productivity convergence", OECD Economics Department Working Paper, No. 509.

\section{Degree of corporatism:}

Definition: indicator of the degree of centralisation/co-ordination of the wage bargaining processes, which takes values 1 for decentralised and unco-ordinated processes, and 2 and 3 for intermediate and high degrees of centralisation/co-ordination, respectively. The "high corporatism" dummy variable frequently used in this paper takes value 1 when bargaining is centralised or co-ordinated and zero otherwise.

Source: OECD, Employment Outlook 2004.

Data adjustments: original data are five-year averages and classify countries in each period along a 0-5 scale from least to most "corporatist" countries. In the present paper, annual data have been reconstructed based on various sources on the timing of past changes in centralisation and/or co-ordination of wage bargaining. Furthermore, the indicator has been rescaled along a 1-3 scale. In this process, it has been assumed that wage bargaining in France predominantly occurs at the intermediate level, while original data describe it as a mix of firm-level and industry-level bargaining. Similarly, in Denmark and Portugal the original indicator fluctuates from high to intermediate throughout the whole estimation period. It has been assumed that such fluctuations are unlikely to occur in the real world and would introduce a lot of noise in the estimates. Therefore, following Nicoletti, G., A. Bassanini, E. Ernst, S. Jean, P. Santiago et P. Swaim "Product and labour market interactions in OECD countries", OECD Economics Department Working Paper No. ${ }^{\circ} 314,2001$, high corporatism has been assumed to have prevailed over the whole period in Denmark and intermediate corporatism in Portugal. For other countries, values 1, 2 and 3 correspond to values 1-2, 3 and 4-5 in the original dataset, respectively.

\section{Union density:}

Definition: trade union density rate, i.e. the share of workers affiliated to a trade union, in \%.

Source: OECD, Employment Outlook 2004. 
Data adjustments: data for missing years are obtained by linear interpolation. Furthermore, original data are typically available until 2001 for most OECD countries. Extrapolations have therefore been made in order expand data availability up to 2003. These are mainly based on national sources but, in some cases, an assumption of unchanged union densities over the period 2001-2003 had to be made due to lack of data.

\section{Union coverage:}

Definition: collective bargaining coverage rate, i.e. the share of workers covered by a collective agreement, in \%.

Source: OECD, Employment Outlook 2004. In the case of Ireland, the average bargaining coverage rate is taken from Belot, M. and J. van Ours (2004), "Does the Recent Success of Some OECD Countries in Lowering their Unemployment Rates Lie in the Clever Design of their Labor Market Reforms?", Oxford Economic Papers, Vol. 56.

\section{Public expenditures on active labour market policies (ALMPs):}

Definition: public expenditures on active labour market programmes per unemployed worker as a share of GDP per capita (or public expenditures on active labour market programmes as a share of GDP, depending on econometric specifications), in \%. The five main categories use in the disaggregated analysis are defined as follows:

1. Public employment services (PES) and administration: placement, counselling and vocational guidance, job-search courses, assistance with displacement costs, administration of unemployment benefits, all other administration costs of labour market agencies including running labour market programmes.

2. Labour market training: training for unemployed adults and those at risk, training for employed adults (special training programmes for youth and disabled are excluded).

3. Youth measures: special programmes concerning measures for unemployed and disadvantaged youth, support of apprenticeship and related forms of general youth training.

4. Subsidised employment: targeted measures to promote or provide employment for the unemployed and other priority groups (but not youth and the disabled).

5. Measures for the disabled: special programmes concerning vocational rehabilitation and work for the disabled.

Source: OECD calculations based on OECD, Employment Outlook.

Data adjustments: data for Italy are not available before 1996 in the OECD database; for the purpose of this study, these data have been extrapolated backwards based on the dataset used by Elmeskov, J., J. Martin and S. Scarpetta (1998), "Key Lessons for Labour Market Reforms: Evidence from OECD Countries' Experiences", Swedish Economic Policy Review, Vol. 5.

\section{Minimum wage:}

Definition: ratio of statutory minimum wage to median wage, in \%.

Source: OECD Minimum Wages Database. 


\section{Rate of home ownership:}

Definition: share of owner-occupied housing as a percentage of total occupied housing stock (average over the 1990-2000 period, 2000 observation only for Portugal).

Source: Oswald, A.J. (1999), “The Housing Market and Europe's Unemployment: A NonTechnical Paper", University of Warwick, United Kingdom, May, (www2.warwick.ac.uk/fac/soc) economics/staff/faculty/oswald/homesnt.pdf). Data for Portugal are taken from OECD, Employment Outlook 2005.

\section{Macroeconomic variables}

\section{Output gap:}

Definition: OECD measure of the gap between actual and potential output as a percentage of potential output.

Source: OECD, Economic Outlook 76, December 2004.

\section{Total factor productivity shock:}

Definition: deviation of the logarithm of Total Factor Productivity (TFP) from its trend calculated by means of a Hodrick-Prescott (HP) filter (smoothing parameter $\lambda=100$ ).

Source: OECD calculations based on OECD, Economic Outlook 76. Gross capital stock data for Canada and the United States are drawn from OECD (2003), The Sources of Economic Growth in OECD Countries.

Data adjustments: The calculation proceeds in three steps. First, growth in the Solow residual in the business sector is calculated as: $\Delta \log (\mathrm{TFP})=[\Delta \log (\mathrm{Y})-\alpha \Delta \log (\mathrm{N})+(1-\alpha) \Delta$ $\log (\mathrm{K})] / \alpha$, where $\mathrm{Y}$ refers to real business sector GDP, $\mathrm{N}$ to total employment, $\mathrm{K}$ to the gross capital stock and $\alpha$ to labour income as a share of business sector income. Second, an index $\log$ (TFP) of the logarithm of TFP is obtained by cumulating the annual values of $\Delta \log (\mathrm{TFP}$ ). Finally, the TFP shock variable is computed as the difference between $\log (\mathrm{TFP})$ and its HP filtered trend.

\section{Terms of trade shock:}

Definition: logarithm of the relative price of imports weighted by the share of imports in GDP, i.e. terms of trade shock $=(M / Y){ }^{*} \log \left(P_{M} / P_{Y}\right)$, where $M$ and $Y$ denote total imports and GDP in nominal terms, respectively, and $\left(\mathrm{P}_{\mathrm{M}} / \mathrm{P}_{\mathrm{Y}}\right)$ is the ratio of the deflator of total imports to the GDP deflator.

Source: OECD calculations based on OECD, Economic Outlook 76.

\section{Real interest shock:}

Definition: difference between the 10-year nominal government bond yield (in \%) and the annual change in the GDP deflator (in \%).

Source: OECD calculations based on OECD, Economic Outlook 76 and IMF, International Financial Statistics. 


\section{Labour demand shocks:}

Definition: logarithm of the labour share in business sector GDP purged from the shortrun influence of factor prices.

Source: OECD calculations based on OECD, Economic Outlook 76.

Data adjustments: The methodology follows Blanchard, O. and J. Wolfers (2000), "The Role of Shocks and Institutions in the Rise of European Unemployment: The Aggregate Evidence", The Economic Journal, Vol. 110, No. 462, March. First, measures of real wages and employment in efficiency units are computed as $\mathrm{W}_{\text {efficiency units }}=\left(\mathrm{W} / \mathrm{P}_{\mathrm{Y}}\right) / \mathrm{TFP}$ and $\mathrm{N}_{\text {efficiency units }}=$ $\mathrm{N} *$ TFP, respectively (for details on notations and sources, see the construction of total factor productivity shocks above). The simplest possible measure of labour demand shocks would be the negative of the sum of the logarithm of the ratio of labour input in efficiency units to real output in the business sector, on the one hand, and the logarithm of real wages in efficiency units, on the other hand: $-\left[\log \left(\mathrm{N}_{\text {efficiency units }} / \mathrm{Y}\right)+\log \left(\mathrm{W}_{\text {efficiency units }}\right)\right]=-\log \left[\left(\mathrm{N}^{*} \mathrm{TFP}\right) /\right.$ $\mathrm{Y}]-\log \left[\left(\mathrm{W} / \mathrm{P}_{\mathrm{Y}}\right) / \mathrm{TFP}\right]=-\log \left[(\mathrm{W} * \mathrm{~N}) /\left(\mathrm{P}_{\mathrm{Y}}{ }^{*} \mathrm{Y}\right)\right]=-($ labour's share of business sector income $)$. However, this simple measure of labour demand shocks is accurate only to the extent that the production function is Cobb-Douglas and factor proportions adjust instantaneously to changes in factor prices. Insofar as the latter assumption is unlikely to be verified in the shortrun, changes in the labour share reflect both genuine labour demand shocks and the lagged adjustment of factor proportions to changes in factor prices.

Therefore, it is necessary to purge the labour share from the short-run influence of factor prices. For simplicity and comparative purposes, this is done here by following the same methodology as Blanchard (1998), "Revisiting European Unemployment: Unemployment, Capital Accumulation and Factor Prices", NBER Working Paper No. 6566, May. Concretely, a wage measure which takes into account the gradual adjustment of factor proportions is computed as: $\log \left(\mathrm{W}_{\text {adjusted }}\right)=\lambda{ }^{*} \log \left(\mathrm{W}_{\text {adjusted }}\right)+(1-\lambda) * \log \left(\mathrm{W}_{\text {efficiency units }}\right)$, where the value of parameter $\lambda$ is set equal to 0.8 in line with estimates on annual data provided by Blanchard. The labour demand shock is then constructed as $-\left[\log \left(\mathrm{N}_{\text {efficiency units }} / \mathrm{Y}\right)+\log \left(\mathrm{W}_{\text {eadjusted }}\right)\right]$. The negative sign implies that an increase in this variable should be interpreted as an adverse labour demand shock. Finally, this variable is set equal to zero in 1970 (or in the first year of data availability for those countries where long time series are unavailable).

Descriptive statistics of all variables are reported in Tables A2-A3. 
Table A2. Descriptive statistics of variables used in the unemployment regressions, 1982-2003

\begin{tabular}{|c|c|c|c|c|c|}
\hline Variable & Mean & $\begin{array}{l}\text { Standard } \\
\text { deviation }\end{array}$ & Maximum & Minimum & $\begin{array}{c}\text { Number of } \\
\text { observations }\end{array}$ \\
\hline Unemployment rate (\%) & 7.76 & 4.19 & 24.04 & 0.40 & 434 \\
\hline Average benefit replacement rate (\%) & 29.68 & 12.63 & 64.94 & 0.35 & 434 \\
\hline Initial benefit replacement rate (\%) & 48.03 & 19.80 & 88.80 & 1.04 & 434 \\
\hline Benefit duration (years) & 0.65 & 0.23 & 1.64 & 0.32 & 434 \\
\hline Tax wedge (\%) & 28.66 & 8.97 & 45.50 & 6.40 & 434 \\
\hline Tax wedge National Accounts (\%) & 44.00 & 9.86 & 63.56 & 26.19 & 398 \\
\hline Labour tax wedge National Accounts (\%) & 27.09 & 6.05 & 41.72 & 16.86 & 398 \\
\hline Consumption taxes (\%) & 16.87 & 5.58 & 28.62 & 6.09 & 411 \\
\hline EPL & 2.07 & 1.09 & 4.19 & 0.20 & 434 \\
\hline EPL regular contracts & 2.08 & 1.00 & 5.00 & 0.17 & 434 \\
\hline EPL temporary contracts & 2.07 & 1.48 & 5.38 & 0.25 & 434 \\
\hline PMR & 3.81 & 1.29 & 6.00 & 1.05 & 434 \\
\hline Union density (\%) & 39.55 & 20.52 & 83.86 & 8.20 & 434 \\
\hline High corporatism & 0.55 & 0.50 & 1.00 & 0.00 & 434 \\
\hline Intermediate corporatism & 0.20 & 0.40 & 1.00 & 0.00 & 434 \\
\hline Low corporatism & 0.25 & 0.43 & 1.00 & 0.00 & 434 \\
\hline High union coverage & 0.72 & 0.45 & 1.00 & 0.00 & 434 \\
\hline Minimum wage (\%) & 45.79 & 10.32 & 64.21 & 28.97 & 217 \\
\hline ALMP (\%) & 27.94 & 25.15 & 179.13 & 3.28 & 332 \\
\hline Training (\%) & 7.44 & 7.85 & 54.57 & 0.28 & 324 \\
\hline Youth measures (\%) & 2.72 & 2.97 & 21.03 & 0.00 & 324 \\
\hline Subsidised employment (\%) & 6.19 & 6.11 & 33.93 & 0.07 & 324 \\
\hline PES (\%) & 5.57 & 4.50 & 25.46 & 0.00 & 324 \\
\hline Measures for disabled (\%) & 6.45 & 11.85 & 83.58 & 0.00 & 332 \\
\hline Output gap (\%) & -0.89 & 2.53 & 6.30 & -12.21 & 434 \\
\hline TFP shock & 0.00 & 0.02 & 0.05 & -0.10 & 419 \\
\hline Terms of trade shock & -0.04 & 0.07 & 0.19 & -0.23 & 434 \\
\hline Interest rate shock (\%) & 4.61 & 2.25 & 14.12 & -9.28 & 434 \\
\hline Labour demand shock & 0.03 & 0.06 & 0.24 & -0.14 & 397 \\
\hline
\end{tabular}


Table A3. Descriptive statistics of variables used in the unemployment regressions, 1970-2003

\begin{tabular}{|c|c|c|c|c|c|}
\hline Variable & Mean & $\begin{array}{l}\text { Standard } \\
\text { deviation }\end{array}$ & Maximum & Minimum & $\begin{array}{c}\text { Number of } \\
\text { observations }\end{array}$ \\
\hline Unemployment rate (\%) & 6.45 & 4.14 & 24.04 & 0.09 & 669 \\
\hline Average benefit replacement rate (\%) & 26.85 & 13.34 & 64.94 & 0.00 & 674 \\
\hline Tax wedge (National Accounts, \%) & 43.07 & 9.96 & 63.56 & 21.28 & 522 \\
\hline Union density (\%) & 42.06 & 19.37 & 83.86 & 7.38 & 654 \\
\hline $\begin{array}{l}\text { Collective bargaining coverage } \\
\text { (average by country, \%) }\end{array}$ & 66.99 & 22.50 & 95.00 & 19.33 & 674 \\
\hline High corporatism & 0.57 & 0.49 & 1.00 & 0.00 & 674 \\
\hline EPL (average by country) & 2.09 & 1.07 & 3.90 & 0.20 & 674 \\
\hline PMR & 4.27 & 1.27 & 6.00 & 1.05 & 674 \\
\hline ALMP (average by country, \%) & 29.82 & 26.78 & 157.48 & 7.02 & 674 \\
\hline Home ownership (average by country) & 0.59 & 0.13 & 0.78 & 0.30 & 20 \\
\hline Output gap (\%) & -0.52 & 2.60 & 16.02 & -12.21 & 616 \\
\hline TFP shock & 0.00 & 0.02 & 0.07 & -0.10 & 622 \\
\hline Terms of trade shock & -0.02 & 0.07 & 0.19 & -0.23 & 654 \\
\hline Interest rate shock (\%) & 2.94 & 3.83 & 14.12 & -14.08 & 674 \\
\hline Labour demand shock & 0.02 & 0.06 & 0.24 & -0.14 & 597 \\
\hline
\end{tabular}

\section{Notes}

1. For further details, see Heady C. (2002), "The "Taxing Wages" Approach to Measuring the Tax Burden on Labour", CESifo Working Paper (Category 1: Public Finance) No. 967, June.

2. Details on the broader PMR indicator for the whole economy - which is available only for 1998 and 2003 and therefore is not used in this paper - can be found in Conway, P., V. Janod and G. Nicoletti (2005) "Product Market Regulation in OECD Countries: 1998 to 2003", Economics Department Working Paper No. 419, OECD, Paris. 